BANCA D'ITALIA

E U R O S I S T E M A

Temi di discussione

(Working Papers)

Bank credit and market-based finance for corporations: the effects of minibond issuances

by Steven Ongena, Sara Pinoli, Paola Rossi and Alessandro Scopelliti

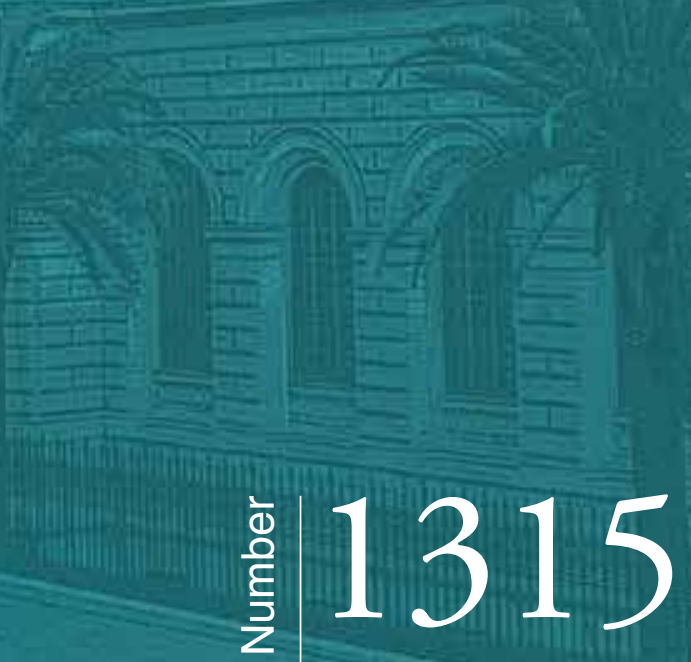



13 BANCA D'ITALIA

E U ROS I S T E M A

\section{Temi di discussione}

(Working Papers)

Bank credit and market-based finance for corporations: the effects of minibond issuances

by Steven Ongena, Sara Pinoli, Paola Rossi and Alessandro Scopelliti

Number 1315 - February 2021 
The papers published in the Temi di discussione series describe preliminary results and are made available to the public to encourage discussion and elicit comments.

The views expressed in the articles are those of the authors and do not involve the responsibility of the Bank.

Editorial Board: Federico Cingano, Marianna Riggi, Monica Andini, Audinga Baltrunaite, Marco Bottone, Davide Delle Monache, Sara Formai, Francesco Franceschi, Adriana Grasso, Salvatore lo Bello, Juho Taneli Makinen, Luca Metelli, Marco Savegnago.

Editorial Assistants: Alessandra Giammarco, Roberto Marano.

ISSN 1594-7939 (print)

ISSN 2281-3950 (online)

Printed by the Printing and Publishing Division of the Bank of Italy 


\title{
BANK CREDIT AND MARKET-BASED FINANCE FOR CORPORATIONS: THE EFFECTS OF MINIBOND ISSUANCES
}

\author{
by Steven Ongena* ${ }^{* \dagger}$, Sara Pinoli ${ }^{\ddagger}$, Paola Rossi ${ }^{\ddagger}$ and Alessandro Scopelliti ${ }^{{ }^{*}}$
}

\begin{abstract}
We study the effects of diversifying funding sources on the financing conditions for firms. We exploit a regulatory reform that took place in Italy in 2012, i.e. the introduction of 'minibonds', which opened a new market-based funding opportunity for unlisted firms. Using the Italian Credit Register, we investigate the impact of minibond issuance on bank credit conditions for issuer firms, both at the firm-bank and firm level. We compare new loans granted to issuer firms with new loans concurrently granted to similar non-issuer firms. We find that issuer firms obtain lower interest rates on bank loans of the same maturity than nonissuer firms do, suggesting an improvement in their bargaining power with banks. In addition, issuer firms reduce the amount of used bank credit but increase the overall amount of available external funds, pointing to a substitution with bank credit and to a diversification of corporate funding sources. Studying their ex-post performance, we find that issuer firms expand their total assets and fixed assets, and also raise their leverage.
\end{abstract}

JEL Classification: G21, G23, G32, G38.

Keywords: bank credit, capital markets, minibonds, loan pricing, SME finance.

DOI: $10.32057 / 0 . T D .2021 .1315$

\section{Contents}

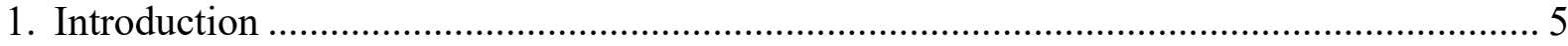

2. Firm capital structure: bank credit and capital markets................................................ 9

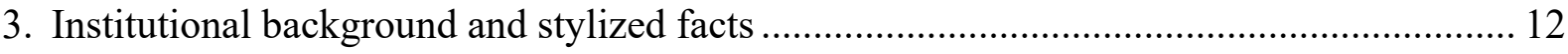

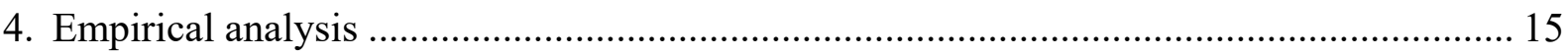

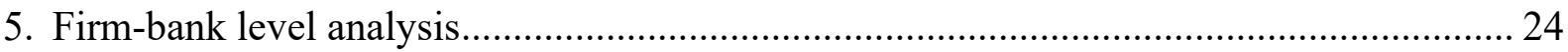

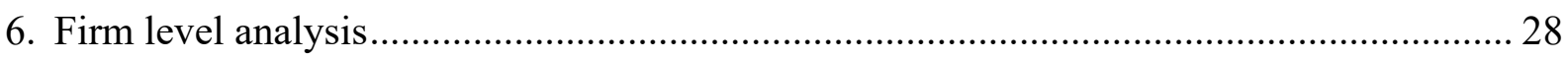

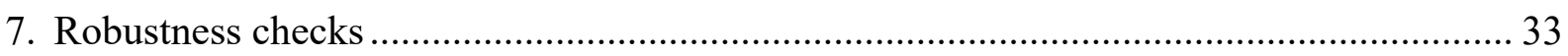

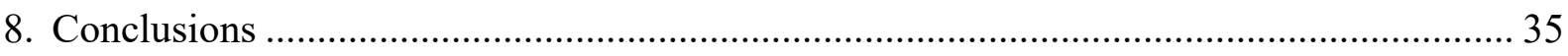

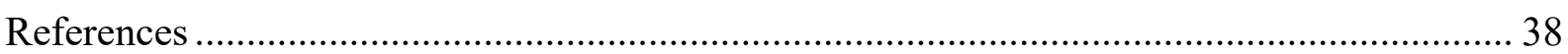

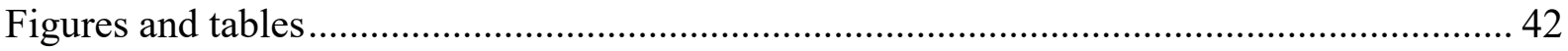

Appendix A. Regressions based on the propensity score matching .................................... 61

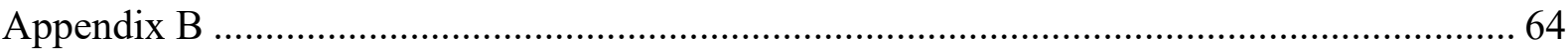

\footnotetext{
* University of Zurich.

$\uparrow$ Swiss Finance Institute, KU Leuven and CEPR.

* Bank of Italy, Economic Research Division, Milan.

$\S$ European Central Bank, DG-Monetary Policy.
} 



\section{Introduction ${ }^{1}$}

The integration between bank credit and market-based finance for corporations is at the center of the current policy debate on the Capital Markets Union in Europe, due to the strong dependence of firms and particularly SMEs on bank credit for their funding needs. This long-standing feature has become even more topical in the discussion on the alternatives to bank credit in the recovery from the Covid-19 crisis (Financial Times, 2020).

Indeed, the shock of the pandemic has put additional pressures on existing vulnerabilities of European banks, and raised some new challenges. Even if the strong response of policy authorities has provided decisive support to bank credit to firms at the peak of the crisis, ${ }^{2}$ the weaknesses of the banking sector accentuated by the shock may hinder its future ability to finance the recovery. In this perspective, easing access to market-based financing sources may reduce firms' overly reliance on bank financing, support their investments and then contribute to economic growth. This strengthens the view that renewed policy commitments to promote the Capital Markets Union are needed now more than ever, in dealing with the challenges of the post-pandemic recovery (De Guindos, Panetta and Schnabel, 2020; High-Level Forum on the Capital Markets Union, 2020; Wieser, 2020).

In previous years, given the strong legacies of the global financial crisis and the sovereign debt crisis for the European banking system, policy authorities had considered various initiatives to extend the range of funding sources for SMEs, including the removal of existing regulatory obstacles to the use of market-based funding. However, progress has been so far limited in the development of the agenda

\footnotetext{
${ }^{1}$ The authors wish to thank Carlo Altavilla, Thorsten Beck, Marina Brogi, Claire Célérier (discussant), Olivier Darmouni, Carmine Di Noia, Annalisa Ferrando, Paolo Finaldi Russo, Xavier Freixas, Mariassunta Giannetti, Christoph Herpfer, Guillaume Horny (discussant), Victoria Ivashina, Angela Maddaloni, Francesco Manaresi, Valentina Michelangeli (discussant), Melina Papoutsi (discussant), Fabio Parlapiano, Francesco Saita, Fabiano Schivardi, Andrea Sironi, Boris Vallée, Zhang Xiang (discussant) and the participants at a workshop held at the Bank of Italy (Rome, December 2018), the Conference "Securities Markets. Trends, Risks and Policies" (Bocconi University, Milan, March 2019), the 2019 Swiss Winter Conference on Financial Intermediation (Lenzerheide, April 2019), the 4th ENTFIN Conference on Entrepreneurial Finance (Trier, July 2019), the Conference on "Regulating Financial Markets" (Goethe University, Frankfurt, August 2019), the Third Annual Workshop of the ESCB Research Cluster 3 on "Financial Stability, Macroprudential Regulation and Microprudential Supervision" (Banco de España, Madrid, October 2019), the 2020 European Economic Association Conference (online, August 2020), a seminar at the European Central Bank (Frankfurt, October 2020), and the 2021 American Finance Association Annual Meeting (virtual, January 2021) for their insightful comments. Ongena and Scopelliti acknowledge financial support from ERC ADG 2016 - GA 740272 lending.

The views presented in this paper are those of the authors and should not be attributed to Banca d'Italia, the European Central Bank or the Eurosystem.

${ }^{2}$ For a recent study on the effects of the monetary, micro- and macroprudential policy measures adopted during the pandemic on bank lending conditions, see Altavilla, Barbiero, Boucinha and Burlon (2020).
} 
for establishing the Capital Markets Union (Bhatia et al., 2019; Constâncio et al., 2019). Now, in light of the fallout from the Covid-19 crisis and of the new financing needs for firms, it is important to assess the effects of some policy initiatives developed in the area of capital markets in recent years, to draw relevant implications for the forthcoming policy design at the European level.

In this paper, we investigate the impact of the diversification of funding sources - following the issuance of corporate bonds - on the financing conditions of issuer firms with a particular focus on their lending relationships with banks. This is particularly relevant for SMEs, as these firms - also in the case of bond issuance - may still rely to a significant extent on bank credit due to the potential benefits of lending relationships. Banks are able to gather soft information about firms and to perform monitoring activity, thus reducing agency costs and providing effective incentives to firms in favor of high-quality investments (Diamond, 1984; Rajan, 1992). The flip side of the coin is that the incumbent banks can extract some monopoly rents due to their informational advantage (hold-up effect; Sharpe, 1990; Von Thadden, 2004) and, consequently, strong dependence on bank credit may lead to an increase in financing costs.

It is therefore crucial to explore whether the diversification of funding sources through capital markets allows issuer firms to improve their bargaining power with banks in setting the credit conditions, and to examine to what extent the ability to issue corporate bonds affects their debt structure. Such empirical analysis presents two main challenges: first, we need to identify an exogenous event enacting the ability of firms to get capital markets funding, such that firms previously unable to issue corporate bonds would then be allowed to do it; second, for a given sample of issuer firms (treated) we have to construct a counterfactual sample of non-issuer firms (control) with ex-ante comparable financial characteristics.

The introduction of a recent regulatory reform in Italy provides an interesting experiment to study the ex-post consequences of bond issuance on corporate credit conditions, within an empirical setting useful to deal with the above challenges. In 2012 a reform aimed at improving the access to capital markets by small and medium enterprises was introduced by the Italian Government. It removed the pre-existing limits to the issuance of corporate bonds by unlisted firms, provided that the securities were negotiated in a regulated market or in a multilateral trading facility. It also extended to these bonds the favorable tax treatment established for the bonds issued by listed firms. Since the new bond issues were expected to be of limited amounts, they were called "minibonds".

We exploit this regulatory shock in order to investigate the ex-post impact of the issuance of minibonds on the financing conditions of Italian corporations, both at the firm-bank level and at the firm 
level. We explore how the recourse to capital markets may have ex-post changed the credit conditions practiced by banks to the issuer firms and the performance of issuer firms.

We study the effects of the switching behavior of firms from bank credit to debt funding, by extending the empirical framework developed by Ioannidou and Ongena (2010) to the issuance of debt instruments. In particular, we analyze whether corporate issuers were able to obtain lower lending rates from banks after the minibond issuance, compared to ex-ante similar non-issuer firms. On one hand, the diversification of funding sources may improve the bargaining power of firms in the lending relationship, so it could eventually lead to an improvement of loan conditions for firms. On the other hand, if the market rates required by investors are still higher than the bank rates, as for the first issuances of minibonds, credit institutions may have relatively less incentive to ease the lending conditions for corporations.

We consider the issuances of minibonds starting from the fourth quarter of 2012 to the end of 2016 and we focus on the first issuance for each firm, as this will provide the first clear message that the firm is able to get funding directly from capital markets. Since the loan offer to a treated firm in the case of non-issuance would not be observable, we match the new loans granted to issuer firms with the new loans granted at the same time to non-issuer firms that have similar pre-determined characteristics. To build the counterfactual sample of non-issuer firms, the existing literature suggests that firm level characteristics - such as credit ratings, net worth, investment opportunities - may play some role in the firms' choice between bank loans and market debt. We allow the selection of issuer versus non-issuer firms to be driven by firms' characteristics rather than by a purely random assignment. This is indeed relevant for the design of our empirical methodology. To deal with these pre-existing differences and reduce the possible endogeneity of the treatment, we implement an exact matching technique on a wide set of ex-ante firms' characteristics and balance sheet performance in order to identify comparable nonissuer firms. We are able to match 92 issuer firms with around 2,700 control firms.

The data combine information from various sources. We merge the deal-level information on minibond issuances by Italian firms with the loan-level data on firm-bank relationships and with the corporate balance sheets of issuer and non-issuer firms. We collect the data on the issuances of minibonds from various sources, including the "Borsa Italiana" (Italy's only stock exchange based in Milan), as minibonds are frequently negotiated on a multilateral trading platform called ExtraMOT Pro and reserved to professional investors. Loan-level data come from the Italian Credit Register ("Centrale dei Rischi"), combined with the quarterly survey on lending rates conducted by the Bank of Italy at the loan-level. 
The effect of the minibond issuance is measured in the quarter of the first issuance and in the following two quarters, compared to the two quarters before the event. ${ }^{3}$ The difference-in-differences analysis on lending rates, both at the firm-bank level and at the firm level, shows that issuer firms obtained - after their first issuance - a reduction in the lending rates charged by banks versus ex-ante similar non-issuer firms. The decrease in lending rates observed at the firm level was around 40 basis points for long-term loans and around 28 basis points for advances. Lending rate reductions of around 30 basis points were also observed in the analysis at the firm-bank level, both for long-term loans and for advances.

The corresponding analysis on lending volumes at the firm level shows that issuer firms reduced the amount of used credit by around 35 percent, suggesting that the minibond issuances were used to substitute part of the previous bank debt. The decrease in the amount of credit granted by banks to issuer firms was smaller (around 10 percent) and not quite statistically significant. Taking into account the two effects combined, after the first issuance issuer firms reduced by around 11 percentage points the ratio between credit used and credit granted, a measure commonly used as a proxy for credit constraints. Considering the amounts raised in the market with the minibond issuance, the overall effect is an increase by around 40 percent of the total external funds the issuer firms can rely upon. Importantly, this significant increase in the total financial debt was achieved by issuer firms without a statistically significant change in their overall financing costs: indeed, the swift reduction in bank lending rates after the first issuance balanced the higher coupon rates on minibond issuances.

These results support the argument that the access to capital markets allows firms to diversify their funding sources and to improve their credit conditions, with a reduction in interest rates on bank debt and an increase in the overall funds they have access to. We find a significant impact of minibond issuances on firm-bank relationships even though these bonds were more costly than bank credit (the average coupon is around 6 percent, 100 basis points more than the average interest rate charged by banks). The results may be explained by the improved bargaining power with the insider banks in setting credit conditions. It may be partially due to the changes in debt composition in favor of long-term debt, which might have enhanced the debt sustainability of issuer firms, in line with previous evidence that shows how bond issuances were used to reduce maturity mismatches between assets and liabilities (Accornero et al., 2015).

\footnotetext{
${ }^{3}$ Our estimates over a longer period, including six quarters after the issuance, show similar results.
} 
Our findings on bank lending conditions and volumes raise the question whether this improvement in financial conditions had some impact on the performance of firms. We estimate a difference-in-differences model for some indicators of asset and liability composition, turnover and profitability. We find that issuer firms - after the first minibond issuance - increase their amount of total assets and of fixed assets, raise their leverage while reducing the share of bank debt out of total financial debt, thanks to the funding diversification. Firms' turnover and profitability are not significantly affected.

Our paper contributes to the literature on the choice between bank credit and market-based finance for corporations. The theoretical literature has investigated benefits and costs associated with this choice, also by identifying firm characteristics that may explain a higher propensity or a better ability to access capital markets funding (Diamond, 1991; Holmstrom and Tirole, 1997). The empirical literature has explored the impact of public listing decisions (for Italy, Pagano, Panetta and Zingales, 1998; for the US, Schenone, 2010), mostly for very large firms. Recent empirical studies on SME finance analyze the developments in firm-bank lending relationships, but we lack studies on the integration between different sources of funding partly due to the limited diffusion of non-bank debt among SMEs.

This analysis provides a first evaluation of the effects of funding diversification on credit conditions and firms' performance, by exploiting a key regulatory reform in Italy aimed at encouraging the issuance of debt instruments by unlisted firms. Italy provides a particularly interesting framework thanks to the large presence of SMEs in the economy and to the multiplicity of firm-bank relationships also for relatively small corporations. Moreover, the reform that introduced minibonds in Italy may be considered a relevant example in the current policy discussion on the regulatory initiatives for the Capital Markets Union, aimed at improving the access to finance for all businesses across Europe (in particular SMEs).

The remainder of the paper is structured as follows. Section 2 reviews the literature on bank credit and capital market finance. Section 3 presents the institutional background and some stylized facts about minibond issuances. Section 4 introduces the data and describes the empirical strategy. Section 5 presents the results of the analysis at the firm-bank level, while Section 6 discusses the analysis at the firm level. Section 7 presents the results of some robustness analyses. Finally, Section 8 concludes.

\section{Firm Capital Structure: Bank Credit and Capital Markets}

The choice among different sources of financing is a complex decision, which depends upon several factors and incentives, both firm-specific and economy-wide, and may have significant 
implications on corporate costs and performance. The traditional corporate finance literature based on the pecking order theory (Myers and Majluf, 1984) has highlighted the role of asymmetric information between the firm and its investors: since the cost of finance increases with asymmetric information, companies would first use internal financing; then, if external financing is required, they would prefer to issue debt rather than new equity, both to avoid the dilution of the existing shares and because investors would perceive debt as less risky than equity due the claim priority. ${ }^{4}$ External debt financing can be drawn from an informed lender, such as a bank, or from an uninformed arm's-length investor (Rajan, 1992).

Banks gather valuable soft information about the economic prospects of corporations through a monitoring activity, which contributes to reduce borrowers' moral hazard and which could not be conducted in a cost-effective way by individual creditors (Diamond, 1984). Established firm-bank relationships may bring some benefits to firms, by increasing the credit availability on a long-term basis, potentially also in crisis times (Petersen and Rajan, 1994; Bolton, Freixas, Gambacorta and Mistrulli, 2016). Moreover, firm-bank relationships allow the borrower a certain degree of flexibility, provided that credit lines typically carry a draw-down option (Berg, Saunders and Steffen, 2016; Sufi, 2009).

Yet, the bank acquires information in the course of the firm-bank relationship, which is proprietary and cannot be communicated to other potential lenders. This gives a larger bargaining power to the bank, which may then extract some surplus from the firm's profits (hold-up effect; Rajan, 1992; Sharpe, 1990). ${ }^{5}$ Therefore, firm-bank relationships may imply higher costs. In von Thadden (2004) outside lenders implement randomization of offers which limit the rents gained by the inside bank. Some firms will switch banks and obtain lower lending rates from the outside bank. Ioannidou and Ongena (2010) analyse empirically the effects of this switching behaviour, showing that the switching firm is charged by the outside bank lower lending rates than the ones required by the inside bank to ex-ante comparable non-switching firms. This incentive to switch in order to reduce financing costs could hold more widely - depending on the financing options available to firms - also for the choice between bank credit and market-based finance. Firms typically take different types of debt from various sources and

\footnotetext{
${ }^{4}$ Since a new equity issuance could be interpreted by market investors as a signal of share overvaluation, managers would refuse to issue undervalued shares in the interest of existing shareholders. The issuance of new stocks, by diluting the value of the existing equity, would transfer part of the firm's wealth from current to new shareholders.

${ }^{5}$ Under asymmetric information, outside banks would not be able to distinguish between good and bad borrowers due to adverse selection (so called 'winner curse') and could not offer better conditions to creditworthy firms. See also Greenbaum et al. (1989).
} 
with different priority structures, and the debt-structure heterogeneity varies in relation to the creditquality distribution of firms (Rauh and Sufi, 2010).

Diamond (1991) shows that new borrowers take initially bank loans but may later issue debt directly, if the positive credit record obtained while monitored generates reputation effects. Therefore, borrowers with higher credit ratings can obtain funding at lower costs from bond issuance, while borrowers with lower credit ratings are subject to bank monitoring. Similarly, according to Holmstrom and Tirole (1997), only firms with sufficiently high net worth would be able to issue bonds, while firms with intermediate capitalisation would have to borrow from intermediaries, and undercapitalised firms would not be able to invest. Rajan (1992) finds a u-shaped relation between investment opportunities and bank borrowing: firms with high-quality projects and those with risky projects will prefer arm's length finance, while firms with medium-risk project will select bank debt. ${ }^{6}$ Likewise, in Bolton and Freixas (2000) the financial structure is endogenously determined by the characteristics of the firm and by the level of intermediation costs.

Consistently with these theoretical predictions, Hoshi, Kashyap and Scharfstein (1993) find that firms having ex-ante higher net worth and investment opportunities were more prone to reduce their reliance on bank debt and issue public debt following the deregulation in Japan during the 1980s. Public borrowers are larger, more profitable and with higher credit ratings with respect to firms borrowing from banks (or from non-bank private lenders) also in Denis and Mihov (2003). Santos and Winton (2008) analyse the pricing of syndicated loans to large firms in the US and provide empirical evidence of the hold-up effect for firms mainly reliant on bank credit versus other firms able to diversify their funding sources via the issuance of corporate bonds. Moreover, the spread paid on loans was higher the longer time passed since the last public bond issuance, thus confirming the informational value of public issuance for the perception of corporate creditworthiness. However, banks maintain a substantial interest rate premium on loans with respect to market financing, even once default risk and covenants are accounted for: this result suggests that either firms place an extra value for bank services that they are willing to pay, or banks maintain a certain degree of information advantage (Schwert, 2017). Darmouni and Papoutsi (2020) document the increase in the use of bond financing in the Euro Area by smaller and riskier firms entering the bond market over the years; however, they show that firms facing a rating downgrade revert to more bank financing.

\footnotetext{
${ }^{6}$ Low-quality firms will prefer arm's length finance rather than bank debt to avoid bank monitoring and the threat of termination.
} 
Pagano, Panetta and Zingales (1998) analyse the effects of IPOs on lending conditions and corporate performance for a sample of Italian firms, by comparing companies that went public with otherwise identical firms that remained private. They find that firms going public managed to decrease their relative cost of credit, particularly in the case of independent companies, with a reduction in the rate between 30 and 55 basis points; independent companies experienced a decrease in the concentration of credit among banks and an increase in the number of banks. More recently, Hale and Santos (2009) show that firms obtain lower interest rates after a bond IPO. Schenone (2010) explores whether the relationship banks exploit their informational advantage by charging higher interest rates than those prevailing under symmetric information for all banks. The analysis, based on loan-level information for syndicated loans, focuses on the IPOs of US companies and uses the borrower's IPO as an informationreleasing event. After the IPO, lending rates decreased particularly for firms with more intense firmbank relationships: by reducing the information asymmetries for the other banks not previously involved in a firm-bank relationship, the IPO decreased the cost of switching banks for the new publicly listed firm. Accornero et al. (2015) show that, besides reputational aspects, two important drivers of the decision to enter the bond market are the needs to finance growth and to reduce maturity mismatches between assets and liabilities.

The above papers suggest that the reduction in lending rates after funding diversification may come from two channels: first, the increase in the bargaining power of firms towards the relationship banks may lower the rates charged by inside banks; second, the public release of information previously available only to the relationship banks may incentivise outside banks to offer better credit conditions. The above arguments may hold differently for different types of additional funding sources: while the bargaining power explanation applies both to new equity and debt issuance, the information release argument depends on the actual amount of information publicly disclosed with the issuance of the new securities. In general, public listing requires the disclosure of a significant amount of information while the release of information could be less significant for the issuance of new debt securities, particularly when they are privately placed. However, even when bonds are publicly issued, some prospectus requirements could be waived under a regulatory framework that aims at decreasing fixed costs for the issuers, like the minibond reform.

\section{Institutional Background and Stylized Facts}

The regulatory reform introduced in Italy in 2012 was aimed at encouraging the issuance of corporate bonds by small and medium enterprises, in a context characterised by strong reliance of the 
corporate sector on bank debt. The reform released some pre-existing regulatory limits to the issuance of corporate debt by unlisted firms and extended the favourable tax regime previously provided only for the debt issuances of listed firms. Cerved Group (2013) estimates that there are about 35,000 Italian companies potentially able to issue minibonds, as they are characterized by an annual turnover of over EUR 5 million and rated as safe or at least financially solvent.

In Italy, corporations heavily depend on the banking system for their funding, although with some relevant differences between large (particularly listed) and small-medium firms. In the recent past, while large corporations could have access to capital markets for the issuance of their bonds, small and medium enterprises could not obtain market-based funding both for economic reasons and for regulatory restrictions.

Among the economic factors, small corporations face significantly higher funding costs on capital markets, due to their opaqueness that increase the informational asymmetries between investors and issuers. Moreover, the recourse to capital markets by Italian SMEs may have been hampered by the limited presence of specialized domestic investors, interested in investing in corporate debt instruments (Accornero, Finaldi Russo, Guazzarotti and Nigro, 2018 and 2015). At the same time, given the national fragmentation of capital markets in the EU, it is unlikely that the debt instruments of Italian SMEs could be purchased by other EU investors.

The need for a larger diffusion of market-based finance for SMEs in Italy and more generally in Europe emerged also as a consequence of the contraction in credit supply by banks during the crisis, particularly for the lending activity to private non-financial corporations. ${ }^{7}$ Indeed, the wide reliance of EU corporations - and in particular of SMEs - on bank credit increased the crisis vulnerability of the corporate sector.

The regulatory framework may add further restrictions to the use of market-based funding for SMEs, especially if it provides differential treatment to firms according to their size.

${ }^{7}$ Becker and Ivashina (2018) argue that the reduction in the credit supply to corporations was also a consequence of a "financial repression" phenomenon in the Euro Area: while National authorities exerted some moral suasion on domestic banks to induce them to increase their holdings of national sovereign debt, banks contracted their credit provision to corporates. Extending the methodology developed in Becker and Ivashina (2014), they find evidence on the cyclicality of bank credit supply based on the financing choices of corporations, which could have used less bank debt and more corporate debt to deal with the contraction in bank credit supply. 


\subsection{The Regulatory Reform and the ExtraMot Pro Platform}

The regulatory reform that introduced minibonds in Italy was carried out in several phases. First, in June 2012, the so called "Decreto Sviluppo" (Law Decree 83/2012, converted in the Law 134/2012) removed the pre-existing limits to the issuance of corporate bonds by unlisted firms (other than microenterprises), provided that the securities are negotiated in a regulated market or in a multilateral trading facility. This legislative act also extended to minibonds the same tax treatment established for the bonds issued by listed firms, including tax relief on interest costs and issuance expenditures, and a preferential tax regime for the interest income gained by investors.

Following these regulatory changes, Borsa Italiana (i.e. Milan Stock Exchange, currently part of the London Stock Exchange) created on March 2013 an ad hoc multilateral trading facility, called ExtraMot Pro, open only to professional investors and designed to offer to corporations, and particularly to SMEs, a flexible and cost-effective market suitable for minibond issuance and trading.

The listing requirements on ExtraMot Pro are simplified with respect to the MOT market (open also to retail investors). Since this multilateral trading facility is open only to professional investors, the listing procedure is not subject to the EU Prospectus Directive and does not need a prior approval by the financial market supervisory authority (CONSOB). Therefore, the time needed for the listing is substantially reduced: the security is admitted to trade within 7 working days from the completion of the initial submission to Borsa Italiana. The issuer is required to publish an Admission Document (or a Prospectus, at the issuer's discretion, mainly for amounts above EUR 200 millions) and the annual financial statements for the last two years (having at least the last one audited). In case a rating (for the firm or the bond issuance) is assigned, the issuer has to disclose it. Listing fee amounts to 2,500 Euros.

Further legislative innovations were introduced mostly to expand the investor base of minibonds. In December 2013, the so called "Decreto Destinazione Italia" (Law Decree 145/2013, converted in Law 9/2014) provided for three main changes, all from the investors' side: 1) it established the eligibility of the minibonds as underlying assets for securitization; 2) it included the minibonds in the set of financial instruments suitable to cover the technical reserves of insurance companies; 3) it applied a preferential tax treatment to the interests and capital gains for the minibonds underwritten by dedicated investment funds. Finally, in June 2014, the so called "Decreto Competitivitá" (Law Decree No. 91/2014, converted in Law 116/2014) extended the favorable tax regime on the interests and capital gains of minibonds not admitted to multilateral trading facilities, as long as they are traded with institutional investors. 


\subsection{Some Stylized Facts on Minibond Issuances}

In the immediate months following the first reform act, the favorable regulatory framework for minibonds was exploited also by relatively large firms, eventually listed, which took the opportunity of the simplified listing procedures to raise funds from public capital markets at cheaper conditions. However, starting from the second half of 2013, also medium and small enterprises took the opportunity to issue minibonds (see Figure 1). The legislative acts adopted after 2012 did not change the regulatory framework for issuers, but, providing further advantages for investors, they enhanced minibonds' demand and could have contributed to reinforce the issuance incentives for small and medium enterprises.

According to the Minibond Observatory (Osservatorio Mini-Bond, 2019), up to the end of 2018, 498 firms issued minibonds, gathering more than EUR 25.2 billion through 746 issuances. Among these firms, 260 are classified as SMEs and they raised debt for an overall amount of EUR 4.6 billion until the end of 2018. For all issuer firms, the average interest rate (generally a fixed coupon) was 5.1 percent, while the average maturity was around 5.3 years.

\section{Empirical Analysis}

\subsection{Data}

The dataset used in the empirical analysis is based on the combination of several data sources: security-level data on the minibond issuances by firms; annual firm level information on corporate balance sheets; and monthly loan-level data on the bank credit amounts and quarterly loan-level data on the lending rates charged by banks to firms.

The data on minibond issuances were mainly collected from the Italian Stock Exchange (Borsa Italiana), since most of the bonds were listed on the ExtraMot Pro Platform (Table 1). Further information on minibond issuances, not listed in ExtraMot Pro Platform, were collected from other sources.

In order to observe a sufficiently long data series for credit conditions after minibonds issuance, we conduct our analysis considering the securities issued up to 2016. We gathered information about 231 minibonds, issued by 148 firms between October 2012 and December 2016, for an overall amount of EUR 8.9 billions in issuance (Table 1). SMEs account for more than 50 percent of the issuers, but less than one tenth of the outstanding amount, given the relatively smaller size of their issuances (Figure 
1). Most of the bonds paid a fixed rate coupon (72 per cent) around 5.8 per cent, on average; therefore, they were more costly than bank credit.

We obtain the balance sheet information for corporations from the Cerved database. ${ }^{8}$ Merging the information on bond issuances with the Cerved database, we get balance sheet information on 92 issuers ('Sample' in Table 1) covering the period 2010-2018. The decrease in the number of issuers is due to the exclusion of firms with financial balance sheets (i.e., holding companies of industrial groups) or without balance sheet data. Cerved also provides Z-scores (Altman, 1968) for most of the firms, as well as information on their economic activity and headquarters. Data show that issuer companies were concentrated in manufacturing and services, were based in the North of Italy and were mainly mediumor large-sized firms according to their total assets (Table 2).

We use quarterly data on bank loans, both for the amounts of credit granted and credit used and for the interest rates charged by banks in the individual firm-bank relationships. Data on bank credit come from the Bank of Italy's Central Credit Register (CR, Centrale dei Rischi). CR covers the population of loans above the threshold of EUR 30,000. For each loan, the database provides information on the lender and borrower identity, the type of credit (credit lines, advances, long-term loans) and the maturity. Data on lending rates charged by banks come from the Bank of Italy's Interest Rate Database (TAXIA). TAXIA includes all the interest rates charged by a sample of more than 200 banks, out of around 600 banks operating in Italy, together with the information about the lender and borrower identity, the type of credit (credit lines, advances, long-term loans) and the maturity. Short-term interest rates (credit lines and advances) refer to all the outstanding positions at a certain point in time, while long-term loans refer to new loans granted in the previous quarter only.

Based on the loan-level data on interest rates, one year before the first issuance, the issuer firms included in the sample displayed an average cost of overall bank debt equal to $4.9 \%$, with some heterogeneity across different types of bank loans (for instance, $5 \%$ on new long-term loans, having a maturity similar to the one of debt securities). While the average coupon rate for the minibonds issued by these firms was on average $6 \%$. The latter means a spread of about 100 basis points compared with the average interest rate charged on new long-term loans to these firms (see Table 3).

\footnotetext{
${ }^{8}$ Cerved is a leading Information Provider in Italy and one of the major rating agencies in Europe. Its database collects the balance sheets of all the Italian corporations since 1982 and a sample of partnerships since 2005 .
} 


\subsection{Identification Strategy}

The introduction of the minibond reform in Italy provides a striking deregulation experiment to study the effects of the diversification of funding sources on the financing conditions for corporations. This applies in particular to small and medium enterprises, and more generally to unlisted firms, given that they have been designated as the key beneficiaries of this policy measure. The discussed regulatory changes - by removing the previous restrictions to the issuance of corporate bonds by unlisted firms opened a new funding opportunity alternative to the traditional bank credit provision. We exploit this innovation to analyse the impact of bond issuance on credit conditions and volumes for the issuer firms, compared with a counterfactual sample of non-issuer firms (that are otherwise similar to the issuers).

We define the ex-ante and the ex-post outcomes with respect to the first minibond issuance: given that the issuance is the event allowing for funding diversification, even if some firms have undertaken more than one issuance over time, the first issuance conveys the very first message to banks that a given firm can obtain finance also from capital markets.

Among all the unlisted firms potentially eligible according to the new regulatory framework, only a few corporations have actually issued and listed minibonds in the ExtraMot Pro platform (or in other multilateral trading facilities). This can be due to several reasons, in particular to firms' characteristics and financial conditions prior to the issuance. Therefore, when defining the sample of control firms, we cannot consider the universe of eligible firms, but we need to construct a counterfactual sample of exante comparable corporations.

Information barriers may have played also some role, by affecting and/or limiting the diffusion of news about the additional funding opportunity across firms. Given the limited experience of unlisted firms with capital market developments, eligible firms could have gained awareness about the new funding alternative in different periods. In some cases - even across firms with the same financial characteristics - the issuance decision could have been the consequence of being actually informed about this possibility. Given the limited contacts of unlisted firms with investment banks, the main bank with which the firm has a long-lasting credit relationship may have then contributed to inform the firm, advising it in favor of or discouraging it from the issuance of minibonds 9 .

${ }^{9}$ The proximity to the headquarters of the Stock Exchange, and more generally to a financial center, may also explain the probability that a firm is informed about this alternative funding opportunity: we account for this in the robustness checks for firm location, as discussed in Section 7.2. 
In the end, we allow the selection of issuer versus non-issuer firms to be driven by firm level characteristics rather than by a purely random assignment. Firms decide whether to issue minibonds on the basis of their existing financial conditions as well as of their forward-looking growth perspectives. This self-selection could have implications for our impact evaluation, if these firm level features influencing the probability of the issuance - were correlated with the outcome variables.

We deal with this issue by implementing an exact matching procedure based on ex-ante firm level characteristics and restricting the analysis to comparable groups of issuers and non-issuers in a way consistent with the unconfoundness assumption. This methodology extends the empirical approach developed by Ioannidou and Ongena (2010) for the switching across banks. ${ }^{10}$ We study the switching behavior from bank credit to debt funding: we consider firms initially taking funds only from banks and then expanding their funding sources with corporate bond issuances. Since the loan offer to a treated firm in the case of non-issuance would not be observable, we compare the loans granted to issuer firms with the loans granted at the same time to non-issuer firms - having the corresponding pre-determined characteristics in the pre-issuance time.

To identify the proper control sample, we consider some observable firm level features measured before the first issuance - which can be relevant for credit conditions and volumes, like the geographical area, economic activity, total assets, the leverage ratio, and the Z-score. Moreover, since we admit that the main bank could have played an important role in informing and advising firms about the possibility to issue minibonds, in selecting the control sample we include also the identity of the main bank among the matching criteria. We also take into account the fact that minibonds were issued in different time periods, so we conduct the exact matching in relation to firm characteristics in the year before the first issuance per each issuer firm. Once we control ex-ante - in the definition of treatment and control samples - for these firm level characteristics, and conditional on them, treatment and outcomes can be assumed to be independent. In this way, we can attribute post-issuance changes in credit conditions to the minibond issuances rather than to other firm-specific factors, which could operate anyway, also in absence of debt issuances.

${ }^{10}$ They investigate whether outside banks offer better credit conditions than insider banks to the switching firms. To this aim, firstly they compare the interest rates charged by the outside bank on the new loans to the switching firm with the rates on existing loans from the inside bank to ex-ante comparable non-switching firms. Secondly, they explore whether the outside bank treats its new borrowers better than its existing ones, by matching - for the outside bank - the new loans to the switching firms with the existing loans to ex-ante comparable nonswitching firms. 
The large size and the wide heterogeneity of the population of eligible firms allow us to fulfill the overlap assumption, i.e., we are able to find - for any setting of the covariates - units in both the treatment and the control groups. The relatively contained number of issuer firms, when compared with the significantly larger universe of eligible firms, puts us in the condition to conduct a very selective exact matching procedure.

\subsection{Control Sample}

We identify the control sample of ex-ante comparable non-issuer firms based on the exact matching for firm level characteristics observed in the year before the first minibond issuance. As a pool of potential controls, we first consider all the Italian firms with turnover and total assets of at least EUR 2 Million in 2014 (as among issuer firms) and reporting balance sheet information in Amadeus-Bureau van Dijk database (around 35,000 firms). Within this sample we define the control group by matching firms' characteristics in the year before the first issuance (from 2011 to 2015, depending on the treated firm) and the identity of the main bank. To reasonably limit the number of matching cells, we apply a Coarsened Exact Matching (CEM), i.e. we discretize our continuous variables. The CEM is designed to reduce the imbalance between the treated and control groups, hence reducing bias and model dependence (Iacus, King and Porro, 2011). Since the treatment (i.e., the first minibond issuance) occurs at different time for each firm, we apply the CEM procedure for each year and assign to each control firm the same time of event of the matched treated firm. ${ }^{11}$ Among pre-treatment characteristics, we consider:

1. At least one bank loan in the pre-treatment year (all the treated fulfill the requirement), without any bond issuance.

2. Firm credit risk (two classes): low risk, Z-score between 1 and 4; medium and high risk, Z-score between 5 and 9 .

3. Leverage ratio (two classes): up to 50 percent; higher than 50 percent

4. Total assets (three classes): ${ }^{12}$ lower than 10 million; 10 to 43 million; greater than 43 million.

11 The exact matching is conducted (with replacement) for each year. We consider the subsample of issuer firms having their first issuance in a given year and we execute the matching on the full sample of potential controls, to identify - per each issuer firm - a sample of control firms. The CEM weights ensure that the parametric analysis reflects the actual observations.

12 The three classes for total assets reflect the EU classification of firms in small, medium and large. 
5. Economic activity (five classes): 1. agriculture and fishing; 2. manufacturing industries; 3 . nonmanufacturing industries (mining, electricity, gas); 4. construction; 5. service industries.

6. Firm location (three areas): North, Center, South.

7. Identity of the main bank for each firm: the main lender bank is defined as the major creditor of the firm, in terms of total credit used, in the year before issuing the minibond. We have 33 different main banks in our sample of treated firms.

We are able to match 92 treated firms with nearly 2,700 control firms (Table 2). By construction, treated and matched control firms display the same distribution for all the variables considered in the Coarsened Exact Matching. The differences between the treated firms and the matched control firms are now negligible as far as economic activity, location, size, Z-score and leverage ratios are concerned, whereas they are quite sizable when compared with the unmatched control firms. As for other balancesheet indicators, in the period before the introduction of minibonds (corresponding to the years 20102012), issuer firms display slightly higher profitability and cost of debt. The share of fixed assets over total assets is similar across treated and control firms, but the growth rate of tangible fixed assets is much higher for treated firms.

For robustness, we conducted also a more stringent coarsened exact matching, introducing more selective criteria for controls ${ }^{13}$. Even though we drop some treated firms and many control firms, the estimates confirm our results in both direction and magnitude. In alternative to the exact matching, we also implemented a propensity score matching using the same selection variables and the estimation results confirm the outcomes based on the coarsened exact matching ${ }^{14}$.

Once we identify - per each issuer firm - a restricted sample of ex-ante comparable firms, we can investigate the effects of the minibond issuances on the credit conditions for issuer firms versus eligible non-issuer firms. We consider the evolution of the firm-bank lending relationships both in terms of credit rates charged by banks to the individual firms, and in terms of volumes of credit used and credit granted.

Table 3 presents some descriptive statistics on interest rates, bank loans and financial debt for issuer and control firms. Consistently with the empirical analysis (see Section 4.4) we considered the

${ }^{13}$ In particular, we consider 3 different classes in the leverage ratio and three different Z-score levels, matching 84 treated firms with around 1500 controls. The results of this estimation are available on request.

${ }^{14}$ Methodology and results are depicted in Appendix A. 
two quarters before the first minibond issuance (before) against the quarter of the first issuance and the following two quarters (after).

Panel 1 displays the average borrowing rates on different types of banks loans, on the overall amount of bank loans and on total financial debt. Advances and long-term loans represent jointly a share of around $90 \%$ of credit used for both issuer and control firms. After the issuance, the pre-existing differences in lending rates between issuer and control firms are significantly reduced for advances and long-term loans, as issuer firms display a stronger decrease in their average lending rates than control firms. ${ }^{15}$ We compute also a composite funding cost for firms, including both bank debt and bond issuances. Consistently with a general declining trend, also the interest rates on total financial debt decrease for both issuer and control firms; however, in this case, the differences in the sample means are still quite sizeable also after the issuance.

Panel 2 presents data on the use of bank debt and the lending relationships. After the issuance, a relevant easing in credit constraints for bank debt is observed for issuer firms: the used share of granted credit decreased substantially for issuer firms, while remaining unchanged for control firms.

Panel 3 displays the amounts of different components of financial debt expressed as percentages of total assets. After the issuance, issuer firms reduce the amount of credit used, while increasing significantly the amount of their financial debt thanks to the minibond issuance. ${ }^{16}$

While the descriptive statistics on the changes in financial conditions after the first issuance between the two groups of issuer and matched control firms point to the expected direction, yet these differences are rarely statistical significant without the proper econometric specification.

\subsection{Difference-in-Differences Specification and Hypothesis Testing}

Based on the exact matching procedure for issuer firms and ex-ante comparable non-issuer firms, we use a difference-in-differences (DID) empirical setting to estimate the changes in lending rates and loan volumes after the first issuance of minibonds.

\footnotetext{
${ }^{15} \mathrm{We}$ compute also the differences in means of each variable comparing the two quarters before with the issuance quarter and the following two quarters, and conduct a two-sample t-test for the statistical significance of the differences-in-means.

${ }^{16}$ This is observed also when classifying the overall sample of firms depending on their size (small, medium and large firms.
} 
The main dependent variables are: a) the interest rates charged in the individual firm-bank relationships, classified by different types of loans, i.e. credit lines, advances and new long-term loans; b) the amounts of granted and used loans, as well as the ratio between credit used and credit granted in firm-bank relationships, estimated both for the overall credit volume and for different types of loans.

The analyses on the first set of dependent variables explore the question whether bond issuances allow corporations to obtain from banks lower lending rates than ex-ante comparable non-issuer firms. The outcome is not obvious. On the one hand, the diversification of funding sources - while reducing the reliance of issuer firms on bank credit - may improve their bargaining power in the firm-bank relationship and eventually lead to better loan conditions. On the other hand, if the market rates required by investors are higher than the bank rates - as it is usually the case for the first issuances of minibonds - banks may have lower incentives to ease lending conditions since the bond market would not be a more attractive source of funding than bank debt. Therefore, no changes in bank lending rates might be observed.

With the second set of dependent variables, we examine whether the issuances of minibonds affected either the volume of credit granted by the banks or the amount actually used by the firm. We can observe different variations for these two variables, as the amounts of granted loans tend to follow a "stickier trend" than used amounts. Indeed, while used amounts reflect the actual funding needs by firms and their preferences about corporate finance composition, granted amounts are mainly determined by the bank's decision about the maximum amount of funds it would be willing to provide to a specific firm. Then we can formulate the relevant hypotheses separately for used and granted amounts.

The impact of minibonds on credit used would crucially depend on the purpose of the issuance, given that the amount of used credit is chosen by the borrower firm as a function of demand factors. If the firm has issued minibonds in order to change the composition of its funding sources, i.e., to substitute bank credit with capital market financing, then we can expect a decrease in the used amounts after the issuance. If the firm plans to start a new project requiring additional funding, the minibond issuance can be used to complement bank credit with capital market financing, then we can expect that the used amount of bank credit would not be subject to significant changes.

The impact of minibonds on credit granted might also reflect supply decisions, which can be either bank- or firm-specific. The bank can modify the granted amounts either for a change in its general lending policy (for example due to tightening or loosening balance sheet constraints) or for some firmspecific reasons (for instance upcoming concerns about the firm's creditworthiness or positive news 
about the firm's profitability). Given that generalized changes to the granted amounts for all firms would be captured by the bank and time fixed effects, the effect of the minibond issuance for the treated firms can be observed if the bank takes the opportunity of the debt issuance to reduce its exposure to the firm, or decides to increase or decrease the granted credit based on the assessment of firm creditworthiness.

In our main specification, we conduct our analysis at the level of individual firm-bank relationships, therefore data are organized as panel data reporting the interest rates and the loan amounts in each period and for each firm-bank credit relationship.

We conduct a difference-in-differences analysis, in which the treatment is defined as whether the firm $i$ has issued minibonds (minibond $=1$ ) or not (minibond $=0$ ). The treatment dummy 'minibond' is also interacted with the dummy 'post', equal to 1 after the first issuance

$$
\text { (1) } \mathrm{Y}_{\mathrm{i}, \mathrm{j}, \mathrm{t}}=\alpha_{\mathrm{i}}+\delta_{j}+\gamma_{t}+\beta_{1} \text { post }_{\mathrm{i}, \mathrm{t}} * \text { minibond }_{\mathrm{i}}+\mathrm{ZControls}_{i, t-4}+\varepsilon_{\mathrm{i}, \mathrm{j}, \mathrm{t}}
$$

We include firm $\left(\alpha_{\mathrm{i}}\right)$, bank $\left(\delta_{j}\right)$, and year $\left(\gamma_{t}\right)$ fixed effects. Given the inclusion of firm and time fixed effects, the coefficient for the interaction between the first minibond issuance (Minibond) and the post-issuance dummy (Post) measures the average treatment effect of the first issuance on interest rates and volumes of credit. ${ }^{17}$ Among the controls, as additional covariates, we consider some firm characteristics: total assets (in logs), leverage, Z-score. All the covariates are measured with a one-year lag. Regressions are weighted with CEM strata weights and standard errors are clustered at the firm level. The effect of the minibond issuance is measured in the quarter of the first issuance and in the following two quarters, compared to the two quarters before the event. Data on the matched control firms cover the same period as the treated firms. As robustness check, we conduct the estimation also on a longer sample including six quarters after the issuance and the results are confirmed.

In order to meet the requirements of a difference-in-differences approach, we verified the common trend assumption, i.e. the outcomes of treated and control firms should follow the same trend in absence of treatment. To check this assumption, we display graphically the dynamics of interest rates, for different categories of loans, and of the share of credit used in the pre-treatment period.

We need to take into account that the treatment (i.e., the first minibond issuance) occurs at different time for each firm, in a period between October 2012 and December 2016. Given that different

\footnotetext{
${ }^{17}$ We started from a standard specification of the type:

$\mathrm{Y}_{\mathrm{i}, \mathrm{j}, \mathrm{t}}=\alpha+\delta_{j}+\beta_{1}$ post $_{\mathrm{i}, \mathrm{t}} *$ minibond $_{\mathrm{i}}+\beta_{2}$ posti $_{\mathrm{i}, \mathrm{t}}+\beta_{3}$ minibond $_{\mathrm{i}}+\mathrm{ZControls}_{i, t-4}+\varepsilon_{\mathrm{i}, \mathrm{j}, \mathrm{t}}$.

Since we introduced firm $\left(\alpha_{\mathrm{i}}\right)$ and year $\left(\gamma_{t}\right)$ fixed effects, the two dummies 'minibond' and 'post' are
} dropped, because of collinearity. 
issuance times were also characterized by different conditions in interest rates and financing costs, we compare the trends in lending rates and volumes by normalizing the levels just before the time of the first issuance (i.e. at the end of the quarter preceding the issuance).

The charts (Figure 2) depict the trends for issuer firms and controls from four quarters before the treatment to six quarters after. Interest rates (by categories of loans) and the share of used credit show similar trends until the time of the issuance event (tevent $=0$ ), with the only exception of the lending rates rate on credit lines. ${ }^{18}$ In the period following the minibond issuance, the effect on interest rates is noticeable for advances and long-term debt and it tends to strengthen through time. On the contrary, the impact on the share of used credit used is immediate and it stabilizes afterwards, pointing to a reimbursement of part of the outstanding loans as a consequence of the market-based finance.

\section{Firm-bank Level Analysis}

In the main specification, we conduct our analysis at the firm-bank level to investigate the effects of the first minibond issuance on the lending rates charged by banks to issuer firms and on the volumes of credit granted by banks and used by firms. Having data at the firm-bank level in every period, we can control for firm, bank and year fixed effects.

\subsection{Empirical Results: Post-Issuance Lending Rates and Volumes}

Table 4 presents the estimates for the impact on lending rates. The coefficient of interest $\left(\beta_{2}\right)$ is negative and significant for advances and long-term loans: after the first minibond issuance, issuer firms obtained a reduction in the lending rates charged by banks on the above categories of loans. In particular, if we look at the specifications with all the control variables (col. 2, 4 and 6), the interest rates lower by around 30 basis points on advances, 28 basis points on long-term debt; on the other hand, the effect on credit lines is not significant.

The decrease in lending rates following the diversification of funding sources can be explained by an increase in the bargaining power of issuer firms and the release of new public information about them. Both arguments could be relevant in this case. The features of the issuance treatment and the

${ }^{18}$ We shall take into account that the lending rates for credit lines are computed on the basis of the outstanding stocks and not of the lending flows. 
design of the minibond reform would however suggest a stronger focus on the bargaining power of issuer firms. The minibond initiative has been introduced to incentivize the issuance of debt instruments by SMEs by minimizing the fixed cost of issuance, then, provided that only professional investors are supposed to purchase these securities, the listing procedures are simplified and the disclosure requirements are less stringent than for standard corporate bonds. Therefore, the first minibond issuance by a company may have a relatively limited information-release effect, but it conveys a strong public signal about its ability to obtain capital markets funding (which is indeed important to explain ex-post its bargaining power with banks). This result holds true even if interest rates on minibonds are typically higher than interest rates on bank credit.

Table 5 reports the estimates of the effects on the amounts of credit granted and used, for the overall credit provision without distinction across types of loan contracts. The results show a reduction in the amount of credit used - at the firm-bank level - by 63 percent after the first minibond issuance. The decrease in credit granted is sensibly lower in terms of magnitude - 11 percent - and is not significant. This reflects the different approach of borrower firms and lender banks after the minibond issuances: while issuer firms replaced bank debt with corporate debt and therefore reduced the amount of bank credit, lender banks were overall still willing to grant credit to these firms and then did not decreased the volumes of credit granted or to a lesser extent. Resulting from these two effects, the ratio between credit used and granted fell by 11 percentage points after the first minibond issuance. The shortterm impact on bank credit volumes is then statistically and economically significant.

The reduction in the amount of credit used can be also interpreted as an automatic consequence of the new funds now available to the firm from capital markets. In principle, there could be some heterogeneity across firms in relation to their financing choices, based on the investment opportunities available at the time of the issuance. While most firms did reduce the amount of credit used to a relevant extent for a substitution across funding sources, a few firms could have used the funding provided by minibond issuances to finance new investment opportunities. In the period under consideration for the issuances, the sovereign debt crisis had strong, negative effects on both economic performance and credit supply, and bond finance could have provided an additional amount of external finance. We will come back to this point in section 6 .

Table 6 displays the regression coefficients for the analysis on the used amounts of specific categories of loans. The reduction effect observed on the overall credit used in Table 5 is confirmed also when we consider separately the different types of loans, though with some differences. The reduction in credit used is larger for credit lines (by 56 percent) than for long-term-loans (by 47 percent). This 
suggests also that minibond issuances may have incentivized a change in the maturity composition of the outstanding bank debt in favor of long-term maturities.

Tables 4, 5 and 6 report estimates on the short time period (from two quarters before up to two quarters after the first minibond issuance). These effects are observed to be persistent over time, also when we estimate the same difference-in-differences regression with an ex-post period including six quarters after the first issuance (Table 7).

Over the longer period, issuer firms obtained - after the first issuance - a reduction in the lending rates on advances by 36 basis points and on long-term loans by 32 basis points, pointing to a slightly larger effect in terms of economic magnitude. This suggests that the benefits of this funding diversification are not purely temporary.

When looking at the lending volumes at the firm-bank level, issuer firms reduced the amount of used bank credit by $59 \%$, while there is no significant variation in the amount of credit granted and the ratio between credit used and credit granted decreased by around 10 percentage points after the first issuance. Therefore, the partial substitution between bank loans and debt issuances is confirmed also in a longer-time horizon, and this occurs even if interest rates on minibonds may be sometimes higher than interest rates on bank loans.

\subsection{Empirical Results: Lending from Insider and Outsider Banks}

The above analysis shows that issuer firms obtain better credit conditions than ex-ante comparable non-issuer firms. In order to disentangle the effect - on the reduction of lending rates - of the bargaining power channel from the information release channel, we explore the potential differences in the lending rate policies by insider and outsider banks. We define as insiders all the banks having a lending relationship with the firm in the 12 months prior to the (first) minibond issuance; we classify as outsiders all the banks which have not provided credit to the firm in the 12 months before the issuance but which extend credit to that firm in the issuance quarter or in the following two quarters. This classification applies correspondingly to the non-issuer firms included in the control sample.

We investigate whether the interest rate reduction may be different in magnitude between insiders and outsiders. The intuition would suggest that the bargaining power argument might apply mainly to insider banks, which already know the firm thanks to the existing lending relationships, whereas the information release argument may be more relevant for outsider banks potentially interested in providing credit to the issuer firm. 
In the end, our specification controls for two types of classification: on the borrower's side, between issuer and non-issuer firms; on the lender's side, between insider and outsider banks. We apply a difference-in-differences-in-differences analysis for treated and untreated firms, in lending relationships with both insider and outsider banks, by estimating the following regression equation:

(2) $Y_{i, j, t}=\alpha_{i}+\delta_{j}+\gamma_{t}+\beta_{1}$ Minibond $_{i} *$ Post $_{i, t}+\beta_{2}$ Minibond $_{i} *$ Post $_{i, t} *$ Outsider $_{i, j, t}$

$$
\begin{aligned}
& +\beta_{3} \text { Minibond }_{i} * \text { Outsider }_{i, j, t}+\beta_{4} \text { Post }_{i, t} * \text { Outsider }_{i, j, t}+\beta_{5} \text { Outsider }_{i, j, t} \\
& +Z \text { Controls }_{i, t-4}+\varepsilon_{i, j, t}
\end{aligned}
$$

Our estimates of (2) can disentangle the effect of the (first) minibond issuance on the lending rates charged to issuer firms by insider and outsider banks. We are mainly interested in the coefficients of the double interaction $\beta_{1}$, measuring the change in lending rate for issuer firms after the first minibond, and of the triple interaction $\beta_{2}$, estimating the variation in the post-issuance rate in the lending relationships with outsider banks. The coefficient of the triple interaction assesses whether the effect of the first minibond issuance on the lending rate is different in the new lending relationships with an outsider bank with respect to an insider bank.

Since outsider banks do not have a lending relationship with the firms in the pre-treatment period, we do not know the interest rate that they would have charged at that time. To construct a counterfactual interest rate for outsider banks before the treatment, we fill the pre-treatment lending rate with the average lending rate by insider banks to that firm before the issuance. This reflects the actual credit conditions obtained by the firm before the treatment. We follow the same approach also for the control firms identified via the exact matching. In this way, we analyze the actual changes in the credit conditions charged to issuer firms by insider and outsider banks, assuming the same pre-issuance rate as starting level; therefore the estimated effect depends only on the post-issuance rates by insiders and outsiders.

Table 8 displays the results of this diff-in-diff-in-diff analysis for different types of loan contracts and for different estimation periods. As before, the post-issuance period includes either the quarter of the issuance and the two following quarters (Col. 1-3) or a longer estimation period considering the quarter of the issuance and the following six quarters (Col. 4-6).

As for the estimation in Table 4, the minibond effects are significant for advances and long-term loans: after the first issuance, issuer firms obtain a rate reduction by 27 bps on advances (Col. 2) and 24 bps on long-term loans (Col. 3). The coefficient on the triple interaction is negative but not significant: this suggests that the effect of the first minibond issuance on the lending rates to issuer firms would not statistically differ in the lending relationships with outsider banks. The post-treatment reduction in 
lending rates for issuer firms seems to be driven by the lending conditions charged by insider banks, supporting the bargaining power explanation of the post-issuance reduction in lending rates. This does not exclude that outsider banks may have incentives to offer more favorable lending conditions in order to start new lending relationships. In line with previous evidence (Ioannidou and Ongena, 2010), in our sample firms obtain a rate reduction by $36 \mathrm{bps}$ on long-term loans by outsider banks after starting a new lending relationship (see the coefficient for the double interaction Outsider*Post in Col. 3). ${ }^{19}$

These results are confirmed also when we consider the longer estimation period, with a rate reduction by 34 bps on advances and by 27 bps on long-term loans, yet without a significant difference between insider and outsider banks (the coefficient for the triple interaction is still not significant).

\section{Firm Level Analysis}

In this section, we analyze the financial and real effects of minibond issuances at the firm level, by investigating both the impact on some credit variables including lending rates and volumes, and the outcome on some firm performance measures and balance sheet indicators. In particular, we explore whether, and to what extent, minibond issuances may have contributed to an overall improvement in the financing conditions of issuer firms with banks and whether this may have produced some effects on the performance of these firms.

\subsection{Bank Debt: Lending Rates and Volumes}

In the analysis of bank debt and financial conditions, we move the focus from the individual firmbank lending relationships (as in the previous section) to the overall bank debt received by a firm. We address two main points: first, whether issuer firms - after the first issuance - observed a change in their average cost of bank funding vis-à-vis ex-ante comparable non-issuer firms; second, whether - after the first issuance - issuer firms changed the overall amount of used bank credit or got a variation in the overall amount of credit granted by banks.

In this way, we want to test whether the results of the analysis for individual firm-bank relationships hold in general also at the firm level: i.e., that firms exploiting the opportunity to issue

\footnotetext{
${ }^{19}$ In fact, when interpreting these results on insider and outsider banks, we need to consider that - given the traditional multiplicity of lending relationships in the Italian credit market - most loans are provided by existing banks and that the loans from new banks represent only a small part of the overall bank debt of the firm.
} 
minibonds not only reduced their overall reliance on bank credit, but also managed to pay lower financing costs on that credit. This would be very important in a policy perspective to assess the effectiveness of the minibond reform.

In this analysis, the dependent variables are: the (weighted) average interest rate paid by a firm on bank loans, also for different types of debt contracts, where the rates paid on individual loans are weighted on the basis on their nominal amounts; the overall amount of bank credit used by a firm or granted to it by all banks. We also analyze the overall amount of financial debt these firms can resort to, considering the used amount of bank debt, the debt provided by other financial intermediaries and the amounts raised with minibond issuances.

Based on the described matching procedure, we conduct a difference-in-differences analysis using the following specification at the firm level:

$$
\text { (3) } \mathrm{Y}_{\mathrm{i}, \mathrm{t}}=\alpha_{\mathrm{i}}+\gamma_{t}+\beta_{1} \text { post }_{\mathrm{i}, \mathrm{t}} * \text { minibond }_{\mathrm{i}}+\mathrm{ZControls}_{i, t-4}+\varepsilon_{\mathrm{i}, \mathrm{t}}
$$

The variables used in this specification, both for the treatment dummy (minibond) and for the firm controls, are defined as in the estimation at the firm-bank level. In this specification we use firm $\left(\alpha_{\mathrm{i}}\right)$ and year $\left(\gamma_{t}\right)$ fixed effects. Tables 9 to 12 present the results for the firm level analysis on credit outcomes: the main effects observed at the firm-bank level are confirmed.

Table 9 displays the results for the lending rates, by categories of loans. As for the firm-bank analysis (Table 4), the coefficients are significant for advances and long-term loans. Following the first minibond, issuer firms obtained overall a decrease in their funding costs through bank advances by 27 basis points and through long-term loans by 40 basis points, based on the specification with the control variables. The sizeable reduction in interest rates for long-term loans, also larger than the one observed in the firm-bank level analysis, confirms that the recourse to capital markets allowed issuer firms to reduce their funding costs particularly for the financing of long-term projects. At the firm level, we consider also the weighted average lending rates for all bank debt, including all categories of loans. ${ }^{20}$ Moreover, to analyze the overall funding costs for firms, we use as a dependent variable also the weighted average interest rate on financial debt as a whole: this is computed as the weighted average of the lending rates on bank loans and of the coupon rates on corporate bonds, considering all the issuances

${ }^{20}$ For completeness, it is useful to report that the interest rates on distinct categories of loans are computed differently: while the lending rates on long-term loans are computed on the new flows of loans initiated in the posttreatment period, the lending rates on advances and credit lines are calculated based on the outstanding amount of these loans in the same period. 
instead of only the first one. Our results confirm the decrease in the cost of bank loans, albeit the estimates are less precise than those by categories of loans. Overall, this reduction in bank lending rates for issuer firms seems to balance the higher cost of minibond issuances. The result of these two counteracting drivers is a negligible impact of minibond issuances on the cost of the total financial debt, which does not differ significantly across treated firms and controls. ${ }^{21}$

The above results at the firm level are observed to be persistent over time also when we estimate equation (3) over a longer post-issuance period, up to six quarters following the issuance (Table 10). Issuer firms obtained - in the six quarters after the first minibond - a reduction in their average cost of bank debt by 35 bps on advances and by 47 bps on long-term loans. Provided that long-term loans account for around two thirds of the overall bank debt and that this share increases after the minibond issuances (see Table 3), issuer firms benefited from a decrease in their average funding costs via bank debt of around $40 \mathrm{bps}$ (estimate for the weighted average interest rates on bank loans). Again, the overall cost of external fund does not change significantly after the issuance for treated against controls firms, suggesting that the reduction in the cost of bank credit compensates the higher cost of minibonds.

Table 11 reports the coefficients of the firm level regressions on credit volumes. As in the firmbank level analysis (Table 5), after the first minibond issuance, issuer firms reduced significantly the amount of used bank credit (by 36 percent) while lender banks decreased only slightly the amount of credit granted to issuer firms (the reduction, around 10 percent, is not significant). As a combination of these two effects, issuer firms decreased the share of used credit by around 11 percentage points. This confirms that issuer firms took the opportunity of the minibond issuance to reduce their reliance on bank credit, even if banks were still willing to provide credit to them.

To analyze the overall debt position of issuer firms, we add other financial debts and the amounts raised with minibond issuances to the overall credit used (Columns 7 and 8). As before, in this case we consider all the issuances instead of only the first one. Our estimates show an increase by around 40 percent in the volume of outstanding debt. We obtain consistent results also when we normalize the amount of financial debt by firms' total assets: after the first minibond, issuer firms reduced this ratio by 10 percentage points. This significant increase in the total financial debt used by firms, associated

${ }^{21}$ However, these results on the overall financing costs have to be interpreted jointly with the results on the overall amount of financial debt, as discussed in Table 11, particularly in light of the increase in the total financial debt. 
with no significant change in the overall funding $\operatorname{cost}^{22}$, suggests that minibonds provided issuer firms with the opportunity to raise a sizeable amount of additional funds without incurring in higher financing costs. It is doubtful whether these firms could have reached the same result only relying on bank debt, both for the difficulties in increasing bank loans to such an extent in a short-time horizon, and for the likely implications of a significant increase in firm leverage on the pricing of bank debt.

Again, also the increase in the amount of available funds and the change in the debt composition of issuer firms appear to be persistent over time. In the six quarters after the first issuance (Table 12), issuer firms reduced the amount of credit used by $35 \%$, while banks decreased the amount of credit granted to the issuer firms by $10 \%$. As a combination of these two effects, the ratio between credit used and credit granted fell by around 10 percentage points in the six quarters after the issuance, suggesting some release in the credit constraints for issuer firms. At the same time, these firms increased their overall amount of financial debt by $39 \%$.

\subsection{Ex-Post Outcomes: Firm Performance and Balance Sheet}

\section{Indicators}

The firm level analysis suggests that firms issuing minibonds managed to improve their financing conditions and to expand the overall amount of financial debt they have access to, while reducing their reliance on bank credit. This raises the question whether this diversification of funding sources had some positive impact also on the ex-post performance of these firms.

We investigate the potential effects of the (first) minibond issuances on firm performance by estimating a difference-in-differences model for some indicators of asset and liability composition, turnover and profitability, by comparing issuer firms versus ex-ante matched non-issuer firms. On the asset side, we consider the log of total assets, total fixed assets, tangible and intangible fixed assets; the ratios of, respectively, total fixed assets, tangible and intangible fixed assets, over total assets. On the liability side, we analyze the ratio of bank debt to total financial debt, the ratio of total financial debt to turnover, and the leverage ratio. In addition, we investigate the log of turnover and two measures of profitability, i.e., the return on assets and the return on equity. We compare firm performance in the year before the issuance and in the two following years. The estimates consider firm and time fixed effects according to the specification:

(4) $\mathrm{Y}_{\mathrm{i}, \mathrm{t}}=\alpha_{i}+\alpha_{t}+\beta_{1}$ post $_{\mathrm{it}} *$ minibond $_{\mathrm{i}}+\varepsilon_{\mathrm{i}, \mathrm{t}}$

\footnotetext{
${ }^{22}$ See the results in Table 9 col. 9-10 for the changes in the overall financing costs of issuer firms.
} 
where Post $t_{t}$ is equal to 1 in the two years following the issuance and 0 in the year before the issuance, while $\alpha_{i}$ and $\alpha_{t}$ are respectively firm and year fixed effects.

Estimates are depicted in Table 13. The average treatment effect of the first issuance on firm balance sheet and performance is measured by the coefficient for the double interaction between minibond $_{\mathrm{it}}$ and post . $_{\text {. }}$

After the issuance, treated firms display an increase in total assets by around 19\% (col. 1), partly as a mechanical effect of the rise in financial resources. The composition of the increase gives some insights on the use of those resources. Total fixed assets rise by around $15 \%$ (col. 2), mainly thanks to the increase in intangible fixed assets, by around 25\% (col. 4); while tangible fixed assets show a modest increase, not statistically significant. Therefore, issuer firms invested more in patents, copyrights, trademarks, possibly financing these additional investments with minibond issuances. Since the postissuance increase in both types of fixed assets was broadly proportional to the increase in total assets, we do not observe any significant change in the ratios of tangible and intangible fixed assets to total assets for treated firms after the issuance.

This asset expansion has been possible thanks to a substantive increase in the amount of total financial debt. Indeed, issuer firms increased their leverage by 10.2 percentage points. However, the increase in leverage was accompanied by a greater diversification of funding sources: issuer firms reduced the share of bank debt out of total financial debt by 23 percentage points.

We explore whether this balance sheet expansion and these investments in fixed assets may have contributed positively to the performance of issuer firms. However, we do not find significant changes in the amount of turnover after the first minibond. Since issuer firms used additional funding to increase particularly their intangible fixed assets, the effects of this on turnover may be somehow delayed. Also, we do not observe relevant changes in the profitability of issuer firms: the coefficient for ROE is not significant, while the significant and negative result for ROA $(-2.49)$ is most likely driven by the increase in total assets.

The results discussed above refer to two years after the first minibond issuance. We also explored the effects of minibonds over a shorter time horizon, one year after the first issuance, and most of the estimated effects are confirmed with the exception of the investments in intangible fixed assets ${ }^{23}$.

\footnotetext{
${ }^{23}$ The results of this specification are available in Appendix B.
} 


\section{Robustness Checks}

We conduct several robustness checks on subsamples differing for bond size and maturity or for firm size and location. Results are reported in Tables 14 and 15.

\subsection{Bond Size and Maturity}

The characteristics of the issued minibonds may be relevant in shaping the effects of the issuance on firms' financing conditions.

The debt maturity profile of issuer firms can affect funding conditions. On one hand, firms which can rely on longer-term funding sources may be perceived as less risky and, therefore, benefit from better financing conditions. As long as debt securities have a longer maturity than bank loans, the observed partial substitution between bank lending and debt issuances may reduce the perceived risk of the issuer firms and lower the lending rates charged by banks. On the other hand, bonds with longer maturity may be subject to higher yields than short-term debt instruments, due to the upward slope of the yield curve. This may limit the incentive to decrease lending rates after the issuance in a bargaining power perspective, as the reduction in bank lending rates to issuer firms may depend on their funding costs via the alternative market funding source. If so, the decrease in lending rates should be smaller for firms issuing longer-term minibonds subject to higher yields. We investigate this issue by estimating the main regressions on a subsample of minibonds with a maturity of at least two years (Panel A in Tables 14 and 15).

Our previous results are broadly confirmed, though with some difference in the magnitude of the effects. In the firm-bank level analysis, firms issuing minibonds with a maturity of at least two years showed a reduction of lending rates on advances by $30 \mathrm{bps}$ and on long-term loans by $19 \mathrm{bps}$ (Table 14 Panel A), slightly less than in the overall sample. However, the results at the firm level (Table 15 Panel A) are very similar to our baseline specification: firms issuing minibonds with longer maturities benefit from a reduction in lending rates by 26 bps on advances and 42 bps on long-term loans. Overall, the estimates on the longer maturity sample do not support the argument about the lower risk perception of more stable funding, but may be consistent with the hypothesis of a lower bargaining power associated with the higher yields for longer-term minibond.

On lending volumes, results on the subsample are similar to the overall sample. Notably, at the firm level, issuer firms reduced their amount of used bank credit by slightly less than the overall sample, 
around 30 percent versus 36 percent. This may be due to a smaller reduction in the more costly shortterm loans, given the lower substitutability between bonds with longer maturity and short-term loans.

The bond issuance amount could also be relevant in explaining the effect of funding diversification, once we control for firm size: minibond issuances of larger amounts may be more effective in increasing firms' bargaining power and as substitutes for bank debt. We investigate this on a subsample of issuances with volume of at most EUR 20 million (Tables 14 and 15, Panel B).

Estimates on lending rates, controlling for firm size and other firm's specific characteristics, are comparable with the overall sample. Instead, the effects on lending volumes are substantially smaller: in the firm-bank level analysis, firms issuing smaller minibonds reduce the amount of used bank credit by around $27 \%$, compared with over $60 \%$ in the overall sample; at the firm level, used bank credit decreases by only $8 \%$, versus $36 \%$ in the overall sample.

These results suggest that debt issuances of smaller amount allow for a more limited substitution between loans and bonds, although the gain on lending rates is not affected.

\subsection{Firm Size and Location}

Different types of firms are likely to benefit from minibond issuance in various ways.

As discussed in Section 3, particularly in the months right after the reform also some large firms took the opportunity to enter the debt capital market by issuing minibonds instead of employing other types of debt securities which were available to them. These firms may have gained better funding conditions, too.

Since the minibond reform was introduced primarily to improve the access to finance for SMEs, we are interested in developing estimates specifically for medium and small firms. For this purpose, we conduct our analysis on a subsample of firms with turnover below or equal to EUR 50 million. ${ }^{24}$ Although this reduces the sample of treated firms, results on SMEs confirm the findings on the overall sample (Tables 14 and 15, Panel C).

At the firm level, the reduction in lending rates is slightly smaller than in the overall sample, but still sizeable (decrease by 31 bps on long-term loans). On the other hand, the substitution between debt

${ }^{24}$ This is one of the criteria used for the classification of medium and small firms. Another criterion is related to the amount of total assets (a firm is defined as a SME if it has an amount of total assets below or equal to EUR 43 million). 
issuance and bank loans is more limited (the amount of used bank credit decrease by $23 \%$ and $8 \%$ at the firm-bank and firm level respectively; the ratio between credit used and credit granted declines by around 6 p.p.). The increase in total financial debt is instead as large as in the overall sample.

These results confirm that SMEs took the opportunity of minibond issuances to increase their leverage by broadening the range of funding sources. The smaller degree of substitution between bank loans and debt issuances, even under the comparable increase in total debt, suggests that minibond issuances were used by SMEs not only to substitute bank lending, but also to obtain additional funding. The smaller reduction in the amount of bank loans, together with the higher risk perception associated with SME lending, may explain the slightly smaller post-issuance decrease in lending rates.

At last, we investigate whether firm location may play some role in firms' capital structure, to the extent that the proximity to financial centers or to stock exchanges may foster information about new funding sources like minibonds. Firms closer to the headquarters of the stock exchange may be better informed and therefore have higher chances to use these new debt instruments. We want to investigate whether our results hold for farther firms as well.

Therefore, we focus on a subsample of firms located outside Lombardy, since the ExtraMot Pro Platform is a multilateral trading platform provided by the Italian Stock Exchange ("Borsa Italiana") with headquarters in Milan; moreover, Milan is the main financial center for Italy, where most investment banks are headquartered.

Estimates on the subsample (Tables 14 and 15, Panel D) confirm the results obtained on the overall sample, both at firm-bank level, and at the firm level. Therefore, the effects described above are robust also to the potential differences in the likelihood to issue minibonds, which could be related to the location of firms.

\section{Conclusions}

This paper analyses the effects of the diversification of funding sources - via the issuance of corporate bonds - on the financing costs and on the debt structure of issuer firms versus ex-ante comparable non-issuer firms. We exploit the introduction of a recent regulatory reform in Italy aimed at removing the existing restrictions on the issuance of corporate bonds by unlisted firms. This reform provides an interesting deregulation experiment as it enabled firms previously relying only on bank credit to get funding also from capital markets through the issuance of the so-called minibonds. 
We focus on minibond issuances between the end of 2012 and the end of 2016. We investigate whether the use of market-based finance allowed issuer firms to obtain more favorable credit conditions in their firm-bank relationships, thanks to an increase in their bargaining power with banks. Given that only some of the many eligible firms issued minibonds, we develop an exact matching procedure to identify - per each issuer firm - a control sample of ex-ante comparable non-issuer firms, according to their size, location, activity and financial characteristics before the first issuance. Then we can identify the impact of the minibond issuance applying a difference-in-differences methodology. The treatment effect is measured in the quarter of the first issuance and in the following two quarters, compared to the two quarters before the event; however, estimates over a longer period - including six quarters after the issuance - show similar results.

Even though minibonds were more costly than bank credit, the analysis shows that issuer firms obtained lower lending rates charged by banks, particularly on long-term loans and advances. This effect is driven by the lending behavior of inside banks, which had existing lending relationships with the issuer firms. These results support the argument that the diversification of funding sources allows firms to reduce the hold-up effect of firm-bank relationships and to increase their bargaining power with banks.

Furthermore, issuer firms changed the composition of their debt structure by decreasing their reliance on bank credit. They reduced significantly the amount of bank credit used while increasing the overall amount of financial debt, suggesting that the minibond issuances led to a partial substitution between bank loans and capital markets funding. Thanks to the issuance of minibonds, the total amount of financial debt taken by issuer firms increased by around 40 percent. Importantly, the large increase in total financial debt was achieved by issuer firms without observing any significant change in their overall financing costs: indeed, the swift reduction in bank lending rates after the first issuance was large enough to balance the higher coupon rates on minibond issuances.

We also explore whether the improvement in financial conditions has any implications on the performance of firms. Comparing one year before with two years after the minibond issuance, we find that issuer firms increase their amount of total assets and of fixed assets, particularly intangible fixed assets, signaling that they invested more in patents, copyrights, trademarks. Moreover, although the leverage of issuer firms raises, their share of bank debt out of total financial debt decreases. Firms' turnover and profitability are not significantly affected, as a longer time horizon may be needed to appreciate the effects of higher funding and investment. 
The conclusions of this analysis have relevant implications for the design of policy initiatives in the domain of the Capital Markets Union, particularly in the current debate on the financing solutions for the recovery of the private sector from the Covid-19 crisis. This paper shows that deregulation reforms removing previous restrictions to the use of market-based finance may provide a significant contribution to promote funding diversification and to increase the amount of financial resources available to firms. Furthermore, provided that small and medium enterprises may still satisfy a significant part of their funding needs through bank credit, this study finds that this diversification can be beneficial in many ways: better financing conditions on bank loans, larger funds availability, a more balanced maturity profile. 


\section{References}

Accornero, M., P. Finaldi Russo, G. Guazzarotti, and V. Nigro (2015). First-time Corporate Bond Issuers in Italy. Bank of Italy Occasional Paper Series, 269

Accornero, M., P. Finaldi Russo, G. Guazzarotti, and V. Nigro (2018). Missing Investors in the Italian Corporate Bond Market. Bank of Italy Occasional Paper Series, 450

Albareto, G., and G. Marinelli (2018). Italian Banks and Market-Based Corporate Financing. Bank of Italy Occasional Paper Series, 432

Altavilla C., F. Barbiero, M. Boucinha, and L. Burlon (2020). The Great Lockdown: Pandemic Response Policies and Bank Lending Conditions. ECB Working Paper Series, 2465

Altman E. I. (1968). Financial Ratios, Discriminant Analysis and the Prediction of Corporate Bankruptcy. The Journal of Finance, 23, 589-609.

Altman, E. I., A. Gande, and A. Saunders (2010). Bank Debt versus Bond Debt: Evidence from Secondary Market Prices. Journal of Money, Credit and Banking, 42 (4), 755-767

Becker, B. and V. Ivashina (2018). Financial Repression in the European Sovereign Debt Crisis. Review of Finance, 22 (1), 83-115

Becker, B. and V. Ivashina (2014). Cyclicality of Credit Supply. Journal of Monetary Economics, 62, 76-93

Berg, T., A. Saunders, and S. Steffen (2016). The Total Cost of Corporate Borrowing in the Loan Market: Don't Ignore the Fees. The Journal of Finance, 71 (3), 1357-1392.

Besanko, D. and G. Kanatas (1993). Credit Market Equilibrium with Bank Monitoring and Moral Hazard. Review of Financial Studies, 6 (1), 213-232

Bhatia, A. V., S. Mitra, A. Weber, S. Aiyar, L. Antound de Almeida, C. Cuervo, A. Oliveira Santos, and T. Gudmundsson (2019). A Capital Market Union for Europe, IMF Discussion Note, 19/07

Bolton, P., X. Freixas, L. Gambacorta, and P. E. Mistrulli (2016). Relationship and Transaction Lending in a Crisis. Review of Financial Studies, 29 (10), 2643-2676 
Bolton, P., and X. Freixas (2000). Equity, Bonds and Market Debt: Capital Structure and Financial Market Equilibrium under Asymmetric Information. Journal of Political Economy, 108 (2), 324351

Boot, A., and A. Thakor (1997). Financial System Architecture. Review of Financial Studies, 10 (3), 693-733

Cerved Group (2013). Is There a Market for Mini-bonds in Italy? A Snapshot of Unlisted Companies. Cerved Group

Constâncio, V., K. Lannoo, and A. Thomadakis (2020). Rebranding Capital Markets Union: A Market Finance Action Plan. Report of a CEPS-ECMI Task Force

Darmouni, O., and M. Papoutsi (2020). The Rise of Bond Financing in Europe. Working Paper

De Guindos, L., F. Panetta, and I. Schnabel (2020). Europe Needs a Fully Fledged Capital Markets Union - Now more than Ever. ECB Blog Post, 2 September 2020

Denis, D.J., and V.T. Mihov (2003). The Choice among Bank Debt, Non-bank Private Debt, and Public Debt: Evidence from New Corporate Borrowings. Journal of Financial Economics, 70, 3-28

Diamond, D. (1991). Monitoring and Reputation: The Choice between Bank Loans and Directly Placed Debt. Journal of Political Economy, 99, 688-721

Diamond, D. (1984). Financial Intermediation and Delegated Monitoring. Review of Economic Studies, $51(3), 393-414$

Drucker, S., and M. Puri (2005). On the Benefits of Concurrent Lending and Underwriting. Journal of Finance, 60 (6), 2763-2799

EU Commission (2015). Building a Capital Markets Union. Green Paper

Financial Times (2020). EU Urged to Make Radical Changes to Boost Investment Sector. 10 June 2020, available at https://www.ft.com/content/68987cd1-3394-4a0c-a6a1-e8ab6c5001bf

Greenbaum, S., G. Kanatas, and I. Venezia (1989). Equilibrium Loan Pricing under the Bank-Client Relationship. Journal of Banking and Finance, 13 (2), 221-235

Hale, G., and J. A. C. Santos (2009). Do Banks Price their Informational Monopoly? Journal of Financial Economics, 93, 185-206. 
High Level Forum on the Capital Markets Union (2020), A New Vision for Europe's Capital Markets, Final Report

Holmstrom, B., and J. Tirole (1997). Financial Intermediation, Loanable Funds and the Real Sector. Quarterly Journal of Economics, 112 (3), 663-691

Hoshi, T., A. Kashyap, and D. Scharfstein (1993). The Choice between Public and Private Debt: an Analysis of Post-Deregulation Corporate Financing in Japan. NBER Working Paper Series, 4421

Iacus, S. M., G. King and G. Porro, (2011). Multivariate Matching Methods That Are Monotonic Imbalance Bounding. Journal of the American Statistical Association, 106 (493), 345-361.

Ioannidou, V., and S. Ongena (2010). "Time for a Change": Loan Conditions and Bank Behavior when Firms Switch Banks. Journal of Finance, 65 (5), 1847-1877

Myers, S. C., and N. S. Majluf (1984). Corporate Financing and Investment Decisions when Firms Have Information that Investors do not Have. Journal of Financial Economics, 13, 187-221

Osservatorio Mini-Bond (2018). $4^{\circ}$ Report Italiano sui Mini-Bond. Politecnico di Milano.

Pagano, M., F. Panetta, and L. Zingales (1998). Why Do Companies Go Public? An Empirical Analysis. Journal of Finance, 53, 27-64

Petersen, M., and R. Rajan (1994). The Benefits of Lending Relationships: Evidence from Small Business Data. The Journal of Finance, 49 (1), 3-37.

Rajan, R. (1992). Insiders and Outsiders: The Choice between Informed and Arms'-Length Debt. The Journal of Finance, 47 (4), 1367-1400

Rauh, J. D., and A. Sufi. (2010). Capital Structure and Debt Structure. The Review of Financial Studies, 23 (12), 4242-4280.

Santos, J. A. C., and A. Winton (2008). Bank Loans, Bonds and Information Monopolies across the Business Cycle. Journal of Finance, 63 (3), 1315-1359

Schenone, C. (2010). Lending Relationships and Information Rents: Do Banks Exploit their Information Advantages? Review of Financial Studies, 23 (3), 1149-1199

Schwert, M. (2020). Does Borrowing from Banks Cost More than Borrowing from the Market? Journal of Finance, forthcoming 
Schwert, M. (2018). Bank Capital and Lending Relationships. The Journal of Finance, 73 (2), 787-830

Sharpe, S. A. (1990). Asymmetric Information, Bank Lending, and Implicit Contracts: A Stylised Model of Customer Relationships. Journal of Finance, 45 (4), 1069-1087

Sufi, A. (2009). Bank Lines of Credit in Corporate Finance: An Empirical Analysis. Review of Financial Studies, 22, 1057-1088.

Von Thadden, E.-L. (2004). Asymmetric Information, Bank Lending and Implicit Contracts: the Winner's Curse. Finance Research Letters, 1 (1), 11-23

Wieser, T. (2020). We Must Resurrect EU Capital Markets Union. Financial Times. 10 June 2020, available at https://www.ft.com/content/7c70a858-79ba-4b3f-af80-7a207e14a558 


\section{Figures and Tables}

\section{Figure 1: Minibond Issuances: Amount and Number of Firms}

This figure displays the composition - in terms of firm size - of the population and of the sample used in the estimates of issuer firms across the years of the first minibond issuance. Firms are classified as small, medium or large in relation to their size based on their total assets, according to EU classification of firms (small: lower than 10 million; medium: 10 to 43 million; large: greater than 43 million). The charts display the composition of firms in terms of overall issuance amounts (in EUR millions, in the panel A) and of number of firms (in units, in the panel B).

\section{Panel A. Issuance amounts by year and firm size}

(population and sample of issuer firms; Millions of Euros)

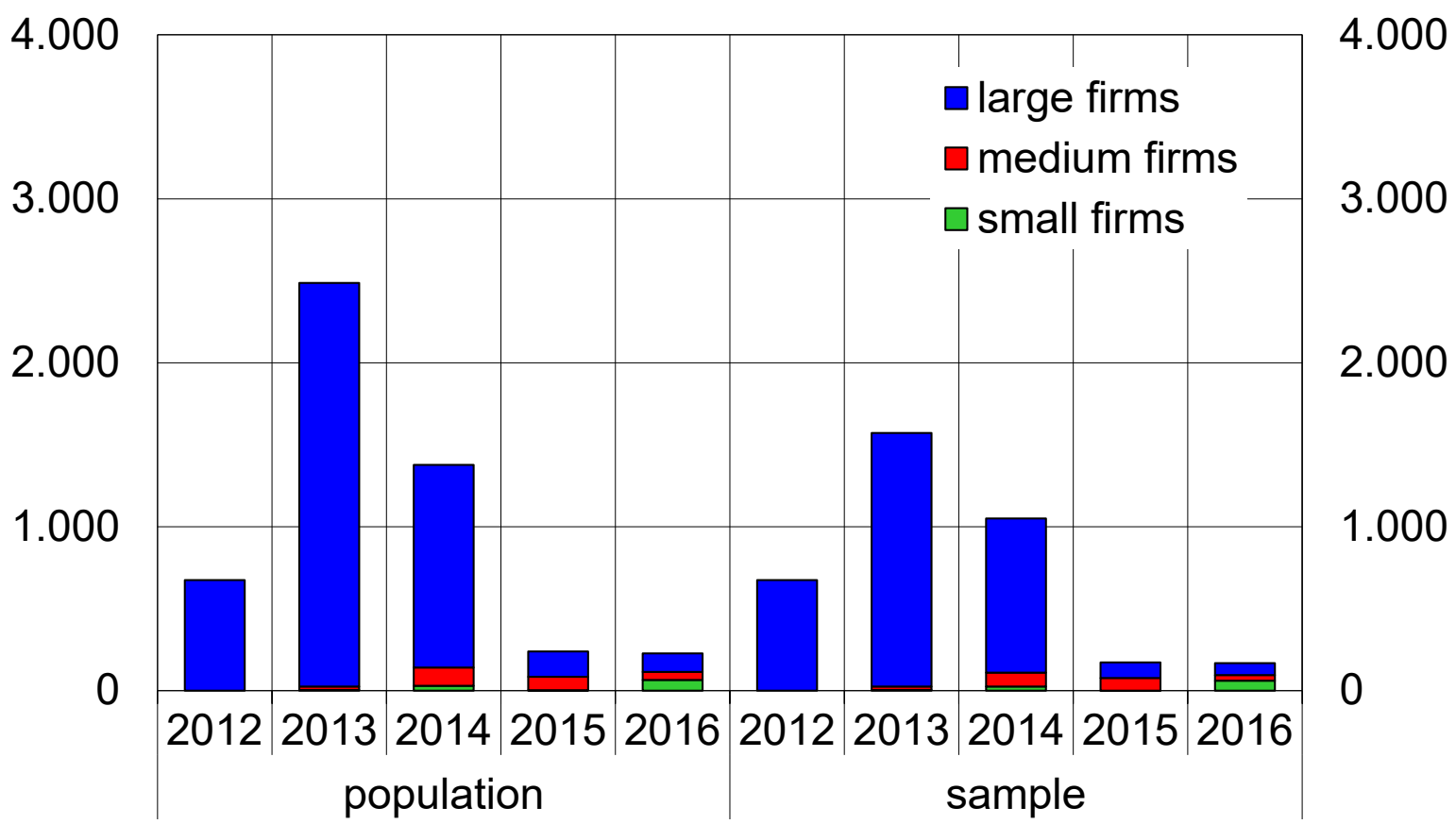

Panel B. Issuer firms by year and size

(population and sample of issuer firms; number of firms)

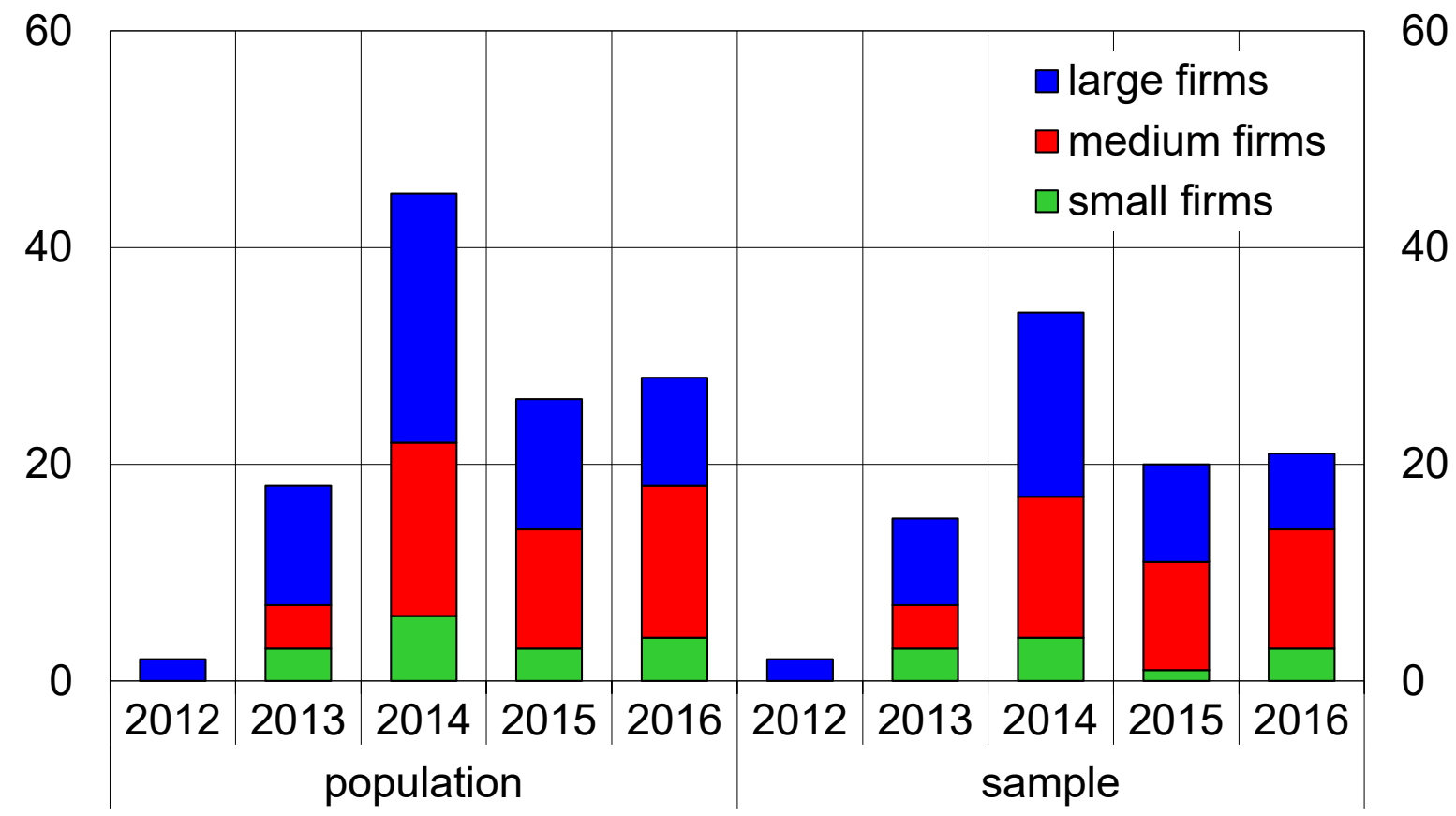




\section{Figure 2: Common Trends for Issuer and Control Firms}

This figure is designed to check the common trends assumption for issuer (treated) firms and matched non-issuer (control) firms. We display graphically the dynamics of interest rates for distinct categories of loans (credit lines, advances and long-term debt) and of the share of credit used over credit granted. Both the lending rates and the ratio of used credit are expressed as weighted averages - at the firm level - provided that the weights are based on the volumes of loans. We take note that the treatment (i.e., the first minibond issuance) occurs at different time for each firm, in a period between October 2012 and December 2016. Given that different issuance periods were also characterised by different conditions in interest rates and financing costs, we compare the trends in lending rates and volumes by normalizing the levels just before the time of the first issuance $(t-1)$. We consider the issuer firms and the control nonissuer firms at the time of treatment, four quarter before and six quarters after the treatment.

Interest rate on credit lines

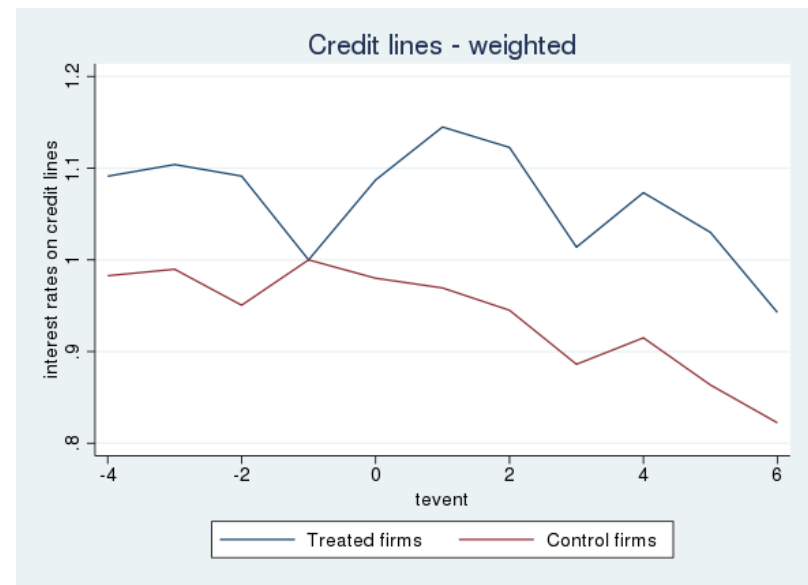

Interest rate on long term debt

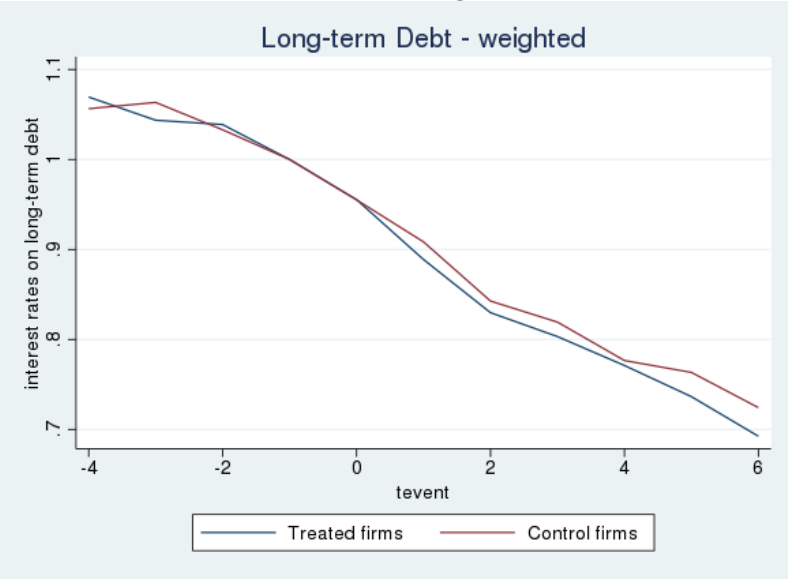

Interest rate on advances

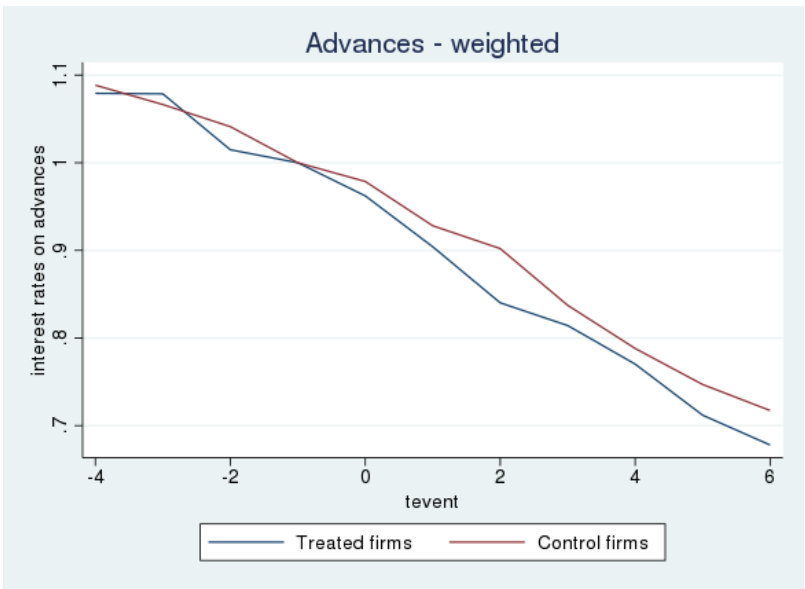

Share of used credit

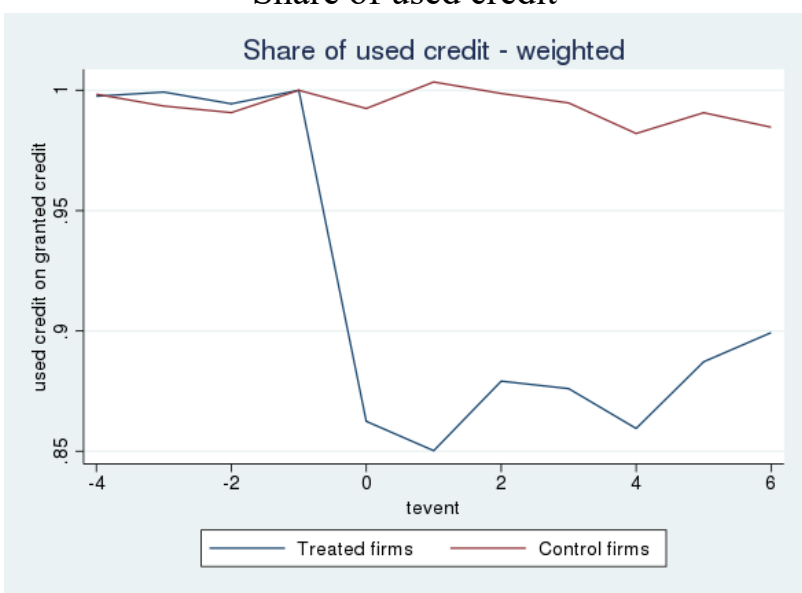


Table 1. Characteristics of Minibond Issuances

This table presents some descriptive statistics about the population and the sample used in the empirical analysis for minibond issuers. The population refers to all the issuances of minibonds, while the sample includes only the issuances of minibonds by firms included as treated in the analysis. Panel A reports - for the minibond issuances - the number of bonds and firms, the share of bonds with fixed rate coupon and the average coupon rate; the minibond issuances are classified by market and by issuance date.

\begin{tabular}{|c|c|c|c|c|c|}
\hline & $\begin{array}{c}\# \\
\text { Bonds }\end{array}$ & $\begin{array}{c}\# \\
\text { Firms }\end{array}$ & $\begin{array}{c}\text { Value } \\
\text { (million Euros) }\end{array}$ & $\begin{array}{c}\text { Share } \\
\text { of fixed interest } \\
\text { rate }(\%)\end{array}$ & $\begin{array}{l}\text { Average } \\
\text { coupon rate }\end{array}$ \\
\hline & \multicolumn{5}{|c|}{ Population of issuer firms } \\
\hline \multicolumn{6}{|l|}{ Market: } \\
\hline ExtraMOT Pro & 188 & 124 & 7,171 & 78.7 & 5.9 \\
\hline Other & 43 & 24 & 1,767 & 38.2 & 5.1 \\
\hline Total & 231 & 148 & 8,937 & 72.5 & 5.8 \\
\hline \multicolumn{6}{|l|}{ Issuance date } \\
\hline 2012 & 2 & 2 & 675 & - & \\
\hline 2013 & 39 & 26 & 3,884 & 82.9 & 7.1 \\
\hline 2014 & 70 & 59 & 1,746 & 79.4 & 5.8 \\
\hline 2015 & 43 & 33 & 406 & 81.0 & 5.4 \\
\hline \multirow[t]{2}{*}{2016} & 77 & 46 & 2,226 & 57.1 & 5.3 \\
\hline & \multicolumn{5}{|c|}{ Sample used in the empirical analysis } \\
\hline \multicolumn{6}{|l|}{ Market } \\
\hline ExtraMOT Pro & 107 & 73 & 2,765 & 83.2 & 6.1 \\
\hline Other & 33 & 19 & 1,417 & 26.9 & 4.9 \\
\hline Total & 140 & 92 & 4,182 & 72.2 & 6.0 \\
\hline \multicolumn{6}{|l|}{ Issuance date } \\
\hline 2012 & 2 & 2 & 675 & - & - \\
\hline 2013 & 18 & 15 & 1,572 & 86.7 & 7.5 \\
\hline 2014 & 40 & 35 & 1,052 & 87.2 & 6.3 \\
\hline 2015 & 27 & 22 & 200 & 84.6 & 5.7 \\
\hline 2016 & 53 & 29 & 683 & 50.9 & 5.3 \\
\hline
\end{tabular}


Table 2 - Characteristics of Minibond Issuers and Control Firms:

\section{Composition and Balance Sheet Data}

This table presents some firm level descriptive statistics regarding the issuer firms and the ex-ante comparable non-issuer firms selected for the control sample. The descriptive statistics present the composition of the two sets of firms according to different variables (economic activity, firm size, firm location, Z-Score) and some balance sheet characteristics before the introduction of the minibond (as median values for the period 2010-2012).

\begin{tabular}{|c|c|c|c|c|c|c|c|}
\hline & $\begin{array}{l}\text { Treated } \\
\text { firms }\end{array}$ & $\begin{array}{l}\text { Control } \\
\text { firms }\end{array}$ & $\begin{array}{l}\text { Potential } \\
\text { control } \\
\text { firms }\end{array}$ & & $\begin{array}{l}\text { Treated } \\
\text { firms }\end{array}$ & $\begin{array}{l}\text { Control } \\
\text { firms }\end{array}$ & $\begin{array}{l}\text { Potential } \\
\text { control } \\
\text { firms }\end{array}$ \\
\hline \multirow[t]{2}{*}{ Observations } & 92 & 2666 & 30120 & Z-score & & & \\
\hline & & & & Low risk & 46.2 & 43.5 & 60.3 \\
\hline $\begin{array}{l}\text { Economic } \\
\text { Activity } \\
\text { Agriculture and } \\
\text { fishing }\end{array}$ & & & & Medium risk & 35.7 & 41.3 & 30.8 \\
\hline nisning & 2.2 & 2.2 & 1.4 & High risk & 18.0 & 15.2 & 8.9 \\
\hline Manufacturing & 45.0 & 45.7 & 37.9 & & & & \\
\hline $\begin{array}{l}\text { Non- } \\
\text { manufacturing }\end{array}$ & 10.4 & 9.8 & 5.4 & $\begin{array}{l}\text { Balance sheet data } \\
\text { (median values, } \\
\text { 2010-12) }\end{array}$ & & & \\
\hline Construction & 4.5 & 4.3 & 6.0 & EBITDA / Assets & 7.09 & 6.47 & 6.95 \\
\hline Service industries & 37.9 & 38.0 & 49.3 & ROA & 4.35 & 3.32 & 3.93 \\
\hline & & & & ROE & 6.35 & 4.9 & 5.83 \\
\hline $\begin{array}{l}\text { Firm size: } \\
\text { (firm's total assets) }\end{array}$ & & & & Leverage (2) & 65.24 & 63.96 & 47.67 \\
\hline Small & 12.5 & 13.0 & 27.7 & Cost of debt/EBITDA & 23.18 & 16.44 & 9.89 \\
\hline Medium & 42.6 & 41.3 & 51.6 & Wages/Turnover & 16.99 & 10.86 & 12.31 \\
\hline Large & 44.9 & 45.7 & 20.6 & $\begin{array}{l}\text { Fixed Assets / Assets } \\
\text { Tangible fixed }\end{array}$ & 0.20 & 0.20 & 0.20 \\
\hline & & & & $\begin{array}{l}\text { assets/Assets } \\
\text { Delta fixed }\end{array}$ & 0.11 & 0.14 & 0.15 \\
\hline Firm Location & & & & $\begin{array}{l}\text { assets/assets }(t-1) \\
\text { Delta tangible Fixed } \\
\text { assets / tangible fixed }\end{array}$ & 0.44 & 0.04 & 0.13 \\
\hline North & 77.2 & 77.2 & 67.2 & assets $(t-1)$ & 3.08 & 0.95 & 3.67 \\
\hline Centre & 12.5 & 13.0 & 18.0 & & & & \\
\hline South and Isles & 10.4 & 9.8 & 13.9 & & & & \\
\hline
\end{tabular}

(1) Based on firm's total assets, according to EU classification of firms (small: lower than 10 million; medium: 10 to 43 million; large: greater than 43 million). (2) The leverage ratio is measured as the share of financial debt over the sum of financial debt and net worth. 


\section{Table 3 - Characteristics of Minibond Issuers and Control Firms:}

\section{Interest Rates, Bank Loans and Financial Debt}

This table presents some firm level descriptive statistics regarding the issuer firms and the ex-ante comparable non-issuer firms selected for the control sample. It reports some firm level characteristics: 1) for the interest rates on different types of banks loans, on all bank loans and on total financial debt; 2) for the composition and use of bank loans, including the ratio between credit used and granted, the composition of credit used and granted, and the number of lending relationships; 3) for the amounts of different types of financial debt, expressed as a percentage of firm total assets. The descriptive statistics report the averages of the quarterly observations for two periods, respectively the two quarters before the issuance of the first minibond (before) and the quarter of the issuance and the following two quarters (after). Please note that the minibonds were issued in different time periods. The table displays also, respectively for treated and control firms, the differences in means of each variable comparing two quarters before with the issuance quarter and the two following quarters, and reports the results of the two-sample t-test for the statistical significance of the differences-in-means. $* * *, * *$ and * indicate, respectively, statistical significance at $1,5,10$ percent level.

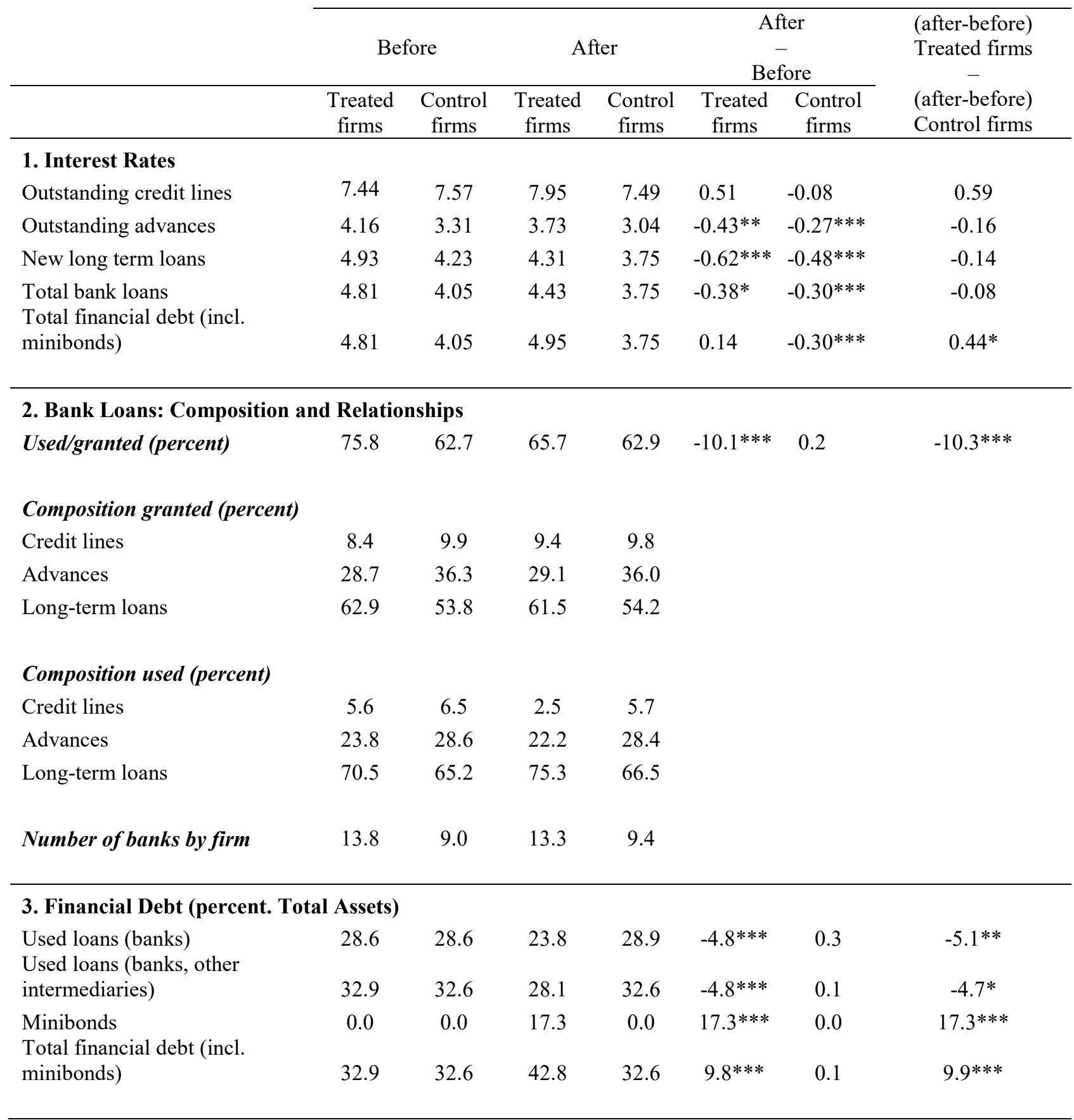




\section{Table 4. Firm-bank Level Analysis}

\section{Effects of the First Minibond Issuance on Lending Rates}

This table presents the results of the difference-in-differences regression for the changes in lending rates at the firmbank level after the issuance of minibonds. The treatment corresponds to the first issuance of a minibond. The control sample includes ex-ante comparable non-issuer firms identified on the basis of a coarsened exact matching based on exante firm level characteristics. The control group is selected in each year, and each firm in the control group is assigned the same time of event of the matched treated firms in that year. The regression includes bank, firm and year fixed effects. Given the inclusion of firm and time fixed effects, the coefficient for the interaction between the first minibond issuance (Minibond) and the post-issuance dummy (Post) defines the average treatment effect of the first issuance on lending rates at the firm-bank level, for different categories of credit contracts (credit lines, advances, long-term loans). We consider two quarters before the first issuance by firm (Post $=0$ ), against the quarter of the issuance and the following two quarters (dummy Post=1). The issuance period considered in the estimates is between the fourth quarter of 2012 and the end of 2016; the overall sample period consider data between June 2012 up until June 2017. The lending rates are expressed in percent rates. While Col. 1, 3 and 5 correspond to the specifications with the fixed effects and the diffin-diff interaction term, Col. 2, 4 and 6 report also the one-year lagged firm level control variables (total assets, leverage and Z-Score). Standard errors are clustered at firm level. Regressions are weighted with CEM strata weights. ***, **, * indicate, respectively, statistical significance at 1, 5, 10 percent level.

\begin{tabular}{|c|c|c|c|c|c|c|}
\hline \multirow{3}{*}{ Minibond * Post } & $(1)$ & $(2)$ & (3) & (4) & $(5)$ & (6) \\
\hline & \multicolumn{2}{|c|}{ Credit lines } & \multicolumn{2}{|c|}{ Advances } & \multicolumn{2}{|c|}{ Long-Term } \\
\hline & $\begin{array}{c}0.052 \\
{[0.155]}\end{array}$ & $\begin{array}{c}0.050 \\
{[0.158]}\end{array}$ & $\begin{array}{c}-0.285^{* * *} \\
{[0.099]}\end{array}$ & $\begin{array}{c}-0.294 * * * \\
{[0.096]}\end{array}$ & $\begin{array}{c}-0.289 * * * \\
{[0.073]}\end{array}$ & $\begin{array}{c}-0.279 * * * \\
{[0.074]}\end{array}$ \\
\hline Ln (Total Assetst -4$)$ & & $\begin{array}{c}0.232 \\
{[0.253]}\end{array}$ & & $\begin{array}{c}0.042 \\
{[0.107]}\end{array}$ & & $\begin{array}{c}-0.222 * \\
{[0.118]}\end{array}$ \\
\hline Leverage $_{t-4}$ & & $\begin{array}{c}-0.009 \\
{[0.007]}\end{array}$ & & $\begin{array}{c}0.007 * * \\
{[0.003]}\end{array}$ & & $\begin{array}{c}0.002 \\
{[0.004]}\end{array}$ \\
\hline Z-Score ${ }_{t-4}$ & & $\begin{array}{c}0.106 \\
{[0.072]}\end{array}$ & & $\begin{array}{c}0.299 * * * \\
{[0.039]}\end{array}$ & & $\begin{array}{c}-0.035 \\
{[0.037]}\end{array}$ \\
\hline Firm FE & YES & YES & YES & YES & YES & YES \\
\hline Bank FE & YES & YES & YES & YES & YES & YES \\
\hline Year FE & YES & YES & YES & YES & YES & YES \\
\hline Observations & 64503 & 64503 & 66458 & 66458 & 49177 & 49177 \\
\hline R-Squared & 0.001 & 0.001 & 0.010 & 0.020 & 0.015 & 0.017 \\
\hline No. Firms & 2549 & 2549 & 2393 & 2393 & 2268 & 2268 \\
\hline No. Issuers & 90 & 90 & 81 & 81 & 86 & 86 \\
\hline
\end{tabular}


Table 5. Firm-bank Level Analysis

\section{Effects of the First Minibond Issuance on Credit Volumes}

This table presents the results of the difference-in-differences regression for the changes in lending volumes at the firmbank level after the issuance of minibonds. The treatment corresponds to the first issuance of a minibond. The control sample includes ex-ante comparable non-issuer firms identified on the basis of a coarsened exact matching based on exante firm level characteristics. The control group is selected in each year, and each firm in the control group is assigned the same time of event of the matched treated firms in that year. The regression includes bank, firm and year fixed effects. Given the inclusion of firm and time fixed effects, the coefficient for the interaction between the first minibond issuance (Minibond) and the post-issuance dummy (Post) defines the average treatment effect of the first issuance on lending volumes at the firm-bank level, respectively for credit used, credit granted and for the ratio between credit used and credit granted, for all the types of credit contracts. We consider two quarters before the first issuance by firm $($ Post $=0)$, against the quarter of the issuance and the following two quarters (dummy Post $=1$ ). The issuance period considered in the estimates is between the fourth quarter of 2012 and the end of 2016; the overall sample period consider data between June 2012 up until June 2017. While Col. 1, 3 and 5 correspond to the specifications with the fixed effects and the diff-in-diff interaction term, Col. 2, 4 and 6 report also the one-year lagged firm level control variables (total assets, leverage and Z-Score). Standard errors are clustered at firm level. Regressions are weighted with CEM strata weights. $* * *, * *, *$ indicate, respectively, statistical significance at $1,5,10$ percent level.

\begin{tabular}{|c|c|c|c|c|c|c|}
\hline & $(1)$ & $(2)$ & $(3)$ & (4) & $(5)$ & $(6)$ \\
\hline & \multicolumn{2}{|c|}{ Credit Used } & \multicolumn{2}{|c|}{ Credit Granted } & \multicolumn{2}{|c|}{ Used / Granted } \\
\hline Minibond $*$ Post & $\begin{array}{c}-0.604 * * * \\
{[0.141]}\end{array}$ & $\begin{array}{c}-0.627 * * * \\
{[0.140]}\end{array}$ & $\begin{array}{c}-0.082 \\
{[0.069]}\end{array}$ & $\begin{array}{c}-0.115 \\
{[0.070]}\end{array}$ & $\begin{array}{c}-0.112^{* * *} \\
{[0.019]}\end{array}$ & $\begin{array}{c}-0.110 * * * \\
{[0.019]}\end{array}$ \\
\hline Ln (Total Assets $\left.{ }_{t-4}\right)$ & & $\begin{array}{c}0.302 * * * \\
{[0.100]}\end{array}$ & & $\begin{array}{c}0.327 * * \\
{[0.139]}\end{array}$ & & $\begin{array}{c}-0.049 * * * \\
{[0.013]}\end{array}$ \\
\hline Leverage $_{\mathrm{t}-4}$ & & $\begin{array}{c}0.013 * * * \\
{[0.003]}\end{array}$ & & $\begin{array}{c}0.007 * * * \\
{[0.002]}\end{array}$ & & $\begin{array}{c}0.001 * * * \\
{[0.001]}\end{array}$ \\
\hline Z-Score $_{\mathrm{t}-4}$ & & $\begin{array}{c}0.055 \\
{[0.052]}\end{array}$ & & $\begin{array}{c}-0.119 * * * \\
{[0.038]}\end{array}$ & & $\begin{array}{c}0.017 * * * \\
{[0.007]}\end{array}$ \\
\hline Firm FE & YES & YES & YES & YES & YES & YES \\
\hline Bank FE & YES & YES & YES & YES & YES & YES \\
\hline Year FE & YES & YES & YES & YES & YES & YES \\
\hline Observations & 99906 & 99906 & 189060 & 189060 & 97213 & 97213 \\
\hline R-Squared & 0.001 & 0.004 & 0.000 & 0.002 & 0.002 & 0.007 \\
\hline No. Firms & 2744 & 2744 & 2758 & 2758 & 2729 & 2729 \\
\hline No. Issuers & 91 & 91 & 92 & 92 & 91 & 91 \\
\hline
\end{tabular}


Table 6. Firm-bank Level Analysis

Effects of the First Minibond Issuance on Credit Used, for Types of Bank Loans

This table presents the results of the difference-in-differences regression for the changes in lending volumes (credit used) at the firm-bank level after the issuance of minibonds. The treatment corresponds to the first issuance of a minibond. The control sample includes ex-ante comparable non-issuer firms identified on the basis of a coarsened exact matching based on ex-ante firm level characteristics. The control group is selected in each year, and each firm in the control group is assigned the same time of event of the matched treated firms in that year. The regression includes bank, firm and year fixed effects. Given the inclusion of firm and time fixed effects, the coefficient for the interaction between the first minibond issuance (Minibond) and the post-issuance dummy (Post) defines the average treatment effect of the first issuance on the volumes of credit used at the firm-bank level, for different categories of credit contracts (credit lines, advances, long-term loans). We consider two quarters before the first issuance by firm (Post=0), against the quarter of the issuance and the following two quarters (dummy Post=1). The issuance period considered in the estimates is between the fourth quarter of 2012 and the end of 2016; the overall sample period consider data between June 2012 up until June 2017. While Col. 1, 3 and 5 correspond to the specifications with the fixed effects and the diff-in-diff interaction term, Col. 2, 4 and 6 report also the one-year lagged firm level control variables (total assets, leverage and Z-Score). Standard errors are clustered at firm level. Regressions are weighted with CEM strata weights. ***, **,* indicate, respectively, statistical significance at 1, 5, 10 percent level.

\begin{tabular}{|c|c|c|c|c|c|c|}
\hline \multirow{3}{*}{ Minibond * Post } & (1) & (2) & (3) & (4) & (5) & (6) \\
\hline & \multicolumn{2}{|c|}{ Credit lines } & \multicolumn{2}{|c|}{ Advances } & \multicolumn{2}{|c|}{ Long-Term } \\
\hline & $\begin{array}{c}-0.570 * * * \\
{[0.102]}\end{array}$ & $\begin{array}{c}-0.563 * * * \\
{[0.101]}\end{array}$ & $\begin{array}{c}-0.532 * * * \\
{[0.096]}\end{array}$ & $\begin{array}{c}-0.513 * * * \\
{[0.099]}\end{array}$ & $\begin{array}{c}-0.430 * * * \\
{[0.155]}\end{array}$ & $\begin{array}{c}-0.468 * * * \\
{[0.156]}\end{array}$ \\
\hline Ln (Total Assetst -4$)$ & & $\begin{array}{l}-0.099 \\
{[0.100]}\end{array}$ & & $\begin{array}{c}-0.449 * * * \\
{[0.126]}\end{array}$ & & $\begin{array}{c}0.526^{* * *} \\
{[0.128]}\end{array}$ \\
\hline Leverage $_{\mathrm{t}-4}$ & & $\begin{array}{c}0.003 \\
{[0.003]}\end{array}$ & & $\begin{array}{c}0.012 * * * \\
{[0.003]}\end{array}$ & & $\begin{array}{c}0.011 * * * \\
{[0.004]}\end{array}$ \\
\hline Z-Score ${ }_{t-4}$ & & $\begin{array}{c}0.102 * * \\
{[0.045]}\end{array}$ & & $\begin{array}{c}0.073 \\
{[0.060]}\end{array}$ & & $\begin{array}{l}-0.033 \\
{[0.052]}\end{array}$ \\
\hline Firm FE & YES & YES & YES & YES & YES & YES \\
\hline Bank FE & YES & YES & YES & YES & YES & YES \\
\hline Year FE & YES & YES & YES & YES & YES & YES \\
\hline Observations & 99906 & 99906 & 99906 & 99906 & 99906 & 99906 \\
\hline R-Squared & 0.002 & 0.003 & 0.001 & 0.006 & 0.001 & 0.005 \\
\hline No. Firms & 2744 & 2744 & 2744 & 2744 & 2744 & 2744 \\
\hline No. Issuers & 91 & 91 & 91 & 91 & 91 & 91 \\
\hline
\end{tabular}


Table 7. Firm-bank Level Analysis

\section{Effects of the First Minibond Issuance on Lending Rates and Volumes (longer post-issuance period)}

This table presents the results of the difference-in-differences regression for the changes in lending rates and volumes at the firm-bank level after the issuance of minibonds. The treatment corresponds to the first issuance of a minibond. The control sample includes ex-ante comparable non-issuer firms identified on the basis of a coarsened exact matching based on ex-ante firm level characteristics. The control group is selected in each year, and each firm in the control group is assigned the same time of event of the matched treated firms in that year. The regression includes firm and year fixed effects. Given the inclusion of firm and time fixed effects, the coefficient for the interaction between the first minibond issuance (Minibond) and the postissuance dummy (Post) defines the average treatment effect - at the firm-bank level - of the first issuance on the lending rates for advances and long-term loans, and on credit volumes for used and granted bank credit, as well as for the ratio between used and granted bank credit (for all the types of credit contracts). We consider two quarters before the first issuance by firm (Post $=0$ ), against the quarter of the issuance and the following six quarters (dummy Post $=1$ ). The issuance period considered in the estimates is between the fourth quarter of 2012 and the end of 2016; the overall sample period consider data between June 2012 up until June 2018. The lending rates are expressed in percent rates. The regression specification includes also the one-year lagged firm level control variables (total assets, leverage and Z-Score). Standard errors are clustered at firm level. Regressions are weighted with CEM strata weights. ***,**,* indicate, respectively, statistical significance at $1,5,10$ percent level.

\begin{tabular}{|c|c|c|c|c|c|}
\hline & \multicolumn{2}{|c|}{ Lending Rates } & \multicolumn{3}{|c|}{ Lending Volumes } \\
\hline & Advances & Long-Term & Credit Used & Credit Granted & Used / Granted \\
\hline Minibond * Post & $\begin{array}{c}-0.361 * * * \\
{[0.116]}\end{array}$ & $\begin{array}{c}-0.321 * * * \\
{[0.099]}\end{array}$ & $\begin{array}{c}-0.588 * * * \\
{[0.143]}\end{array}$ & $\begin{array}{c}-0.106 \\
{[0.088]}\end{array}$ & $\begin{array}{c}-0.099 * * * \\
{[0.019]}\end{array}$ \\
\hline Ln (Total Assetst-4) & $\begin{array}{c}-0.181 * * \\
{[0.082]}\end{array}$ & $\begin{array}{c}-0.272 * * \\
{[0.119]}\end{array}$ & $\begin{array}{c}0.348 * * * \\
{[0.099]}\end{array}$ & $\begin{array}{c}0.427 * * * \\
{[0.129]}\end{array}$ & $\begin{array}{c}-0.037 * * * \\
{[0.012]}\end{array}$ \\
\hline Leverage $_{t-4}$ & $\begin{array}{c}0.007 * * * \\
{[0.002]}\end{array}$ & $\begin{array}{c}0.001 \\
{[0.002]}\end{array}$ & $\begin{array}{c}0.011 * * * \\
{[0.002]}\end{array}$ & $\begin{array}{c}0.010 * * * \\
{[0.002]}\end{array}$ & $\begin{array}{c}0.002 * * * \\
{[0.000]}\end{array}$ \\
\hline Z-Score ${ }_{t-4}$ & $\begin{array}{c}0.280 * * * \\
{[0.027]}\end{array}$ & $\begin{array}{c}0.026 \\
{[0.026]}\end{array}$ & $\begin{array}{c}0.025 \\
{[0.035]}\end{array}$ & $\begin{array}{c}-0.122 * * * \\
{[0.029]}\end{array}$ & $\begin{array}{c}0.014 * * * \\
{[0.004]}\end{array}$ \\
\hline Firm FE & YES & YES & YES & YES & YES \\
\hline Bank FE & YES & YES & YES & YES & YES \\
\hline Year FE & YES & YES & YES & YES & YES \\
\hline Observations & 117551 & 90925 & 179271 & 340308 & 174373 \\
\hline R-Squared & 0.048 & 0.066 & 0.005 & 0.004 & 0.007 \\
\hline No. Firms & 2414 & 2333 & 2745 & 2758 & 2731 \\
\hline No. Issuers & 81 & 86 & 91 & 92 & 91 \\
\hline
\end{tabular}


Table 8. Firm-bank Level Analysis.

\section{Effects of the First Minibond Issuance on Lending Rates: Insider and Outsider Banks}

This table presents the results of the difference-in-differences-in-differences estimation for the changes in lending rates charged at the firm-bank level by insider and outsider banks after the issuance of minibonds. We explore whether the changes in lending rates after the treatment may be different across insider and outsider banks. The treatment corresponds to the first issuance of a minibond. The control sample includes ex-ante comparable non-issuer firms identified on the basis of a coarsened exact matching based on ex-ante firm level characteristics. A bank is defined as outsider in a firm-bank lending relationship, if it has not provided credit in the 12 months before the minibond issuance, but extends credit to the firm in the issuance quarter or in the following ones. For the insider banks, we observe the lending rates charged before and after the minibond issuance. For outsider banks, we observe only the interest rates applied after the issuance, so we compute the counterfactual lending rate for the pre-issuance period as the average interest rate charged to the same firm by the insider banks before the minibond issuance. The regression includes bank, firm and year fixed effects. Given the inclusion of firm and time fixed effects, the coefficient for the interaction between the first minibond issuance (Minibond) and the post-issuance dummy (Post) defines the average treatment effect of the first issuance on lending rates at the firm-bank level, for different categories of credit contracts (credit lines, advances, long-term loans). The coefficient for the triple interaction term (Minibond * Post * Outsider) indicates whether and to what extent the average treatment effect on lending rates varies for the lending relationships with outsider banks. We consider two different estimation periods: in Col. 1-3, we compare the two quarters before the first issuance (Post=0), against the quarter of the issuance and the following two quarters (dummy Post=1); in Col. 4-6, we compare the two quarters before the first issuance $(\mathrm{Post}=0)$, against the quarter of the issuance and the following six quarters (dummy Post=1). The issuance period considered in the estimation is between the fourth quarter of 2012 and the end of 2016 ; the overall sample period include data from the second quarter of 2012 to the second quarter of 2018. The lending rates are expressed in percent rates. Standard errors are clustered at firm level. Regressions are weighted with CEM strata weights. $* * *, * *, *$ indicate, respectively, statistical significance at $1,5,10$ percent level.

\begin{tabular}{|c|c|c|c|c|c|c|}
\hline & \multicolumn{3}{|c|}{$\begin{array}{c}\text { Post }=1 \text { for the issuance quarter and the two } \\
\text { following ones }\end{array}$} & \multicolumn{3}{|c|}{$\begin{array}{c}\text { Post }=1 \text { for the issuance quarter and the six } \\
\text { following ones }\end{array}$} \\
\hline & $\begin{array}{c}(1) \\
\text { Credit lines }\end{array}$ & $\begin{array}{c}(2) \\
\text { Advances } \\
\end{array}$ & $\begin{array}{c}3) \\
\text { Long term }\end{array}$ & $\begin{array}{c}(4) \\
\text { Credit lines } \\
\end{array}$ & $\begin{array}{c}(5) \\
\text { Advances } \\
\end{array}$ & $\begin{array}{c}(6) \\
\text { Long term }\end{array}$ \\
\hline Minibond * Post & $\begin{array}{c}0.052 \\
{[0.149]}\end{array}$ & $\begin{array}{c}-0.270 * * * \\
{[0.091]}\end{array}$ & $\begin{array}{c}-0.240 * * * \\
{[0.064]}\end{array}$ & $\begin{array}{c}0.127 \\
{[0.175]}\end{array}$ & $\begin{array}{c}-0.336^{* * *} \\
{[0.114]}\end{array}$ & $\begin{array}{c}-0.269 * * * \\
{[0.088]}\end{array}$ \\
\hline Minibond * Post* Outsider & $\begin{array}{c}0.383 \\
{[0.804]}\end{array}$ & $\begin{array}{c}-0.218 \\
{[0.194]}\end{array}$ & $\begin{array}{c}-0.034 \\
{[0.172]}\end{array}$ & $\begin{array}{c}0.703 \\
{[0.771]}\end{array}$ & $\begin{array}{c}-0.058 \\
{[0.184]}\end{array}$ & $\begin{array}{c}0.007 \\
{[0.179]}\end{array}$ \\
\hline Minibond * Outsider & $\begin{array}{c}-0.765 \\
{[0.763]}\end{array}$ & $\begin{array}{c}0.009 \\
{[0.119]}\end{array}$ & $\begin{array}{c}-0.063 \\
{[0.129]}\end{array}$ & $\begin{array}{c}-0.934 \\
{[0.773]}\end{array}$ & $\begin{array}{c}-0.066 \\
{[0.131]}\end{array}$ & $\begin{array}{c}-0.077 \\
{[0.139]}\end{array}$ \\
\hline Post* Outsider & $\begin{array}{c}0.377 \\
{[0.274]}\end{array}$ & $\begin{array}{c}-0.018 \\
{[0.115]}\end{array}$ & $\begin{array}{c}-0.362 * * * \\
{[0.056]}\end{array}$ & $\begin{array}{c}0.113 \\
{[0.284]}\end{array}$ & $\begin{array}{c}-0.186 * \\
{[0.098]}\end{array}$ & $\begin{array}{c}-0.521 * * * \\
{[0.048]}\end{array}$ \\
\hline Outsider & $\begin{array}{c}-0.544 \\
{[0.346]}\end{array}$ & $\begin{array}{c}0.234 * * * \\
{[0.082]}\end{array}$ & $\begin{array}{c}0.148 * * * \\
{[0.049]}\end{array}$ & $\begin{array}{c}-0.533 \\
{[0.349]}\end{array}$ & $\begin{array}{c}0.239 * * * \\
{[0.092]}\end{array}$ & $\begin{array}{c}0.185 * * * \\
{[0.048]}\end{array}$ \\
\hline Ln (Total Assetst-4) & $\begin{array}{c}0.227 \\
{[0.252]}\end{array}$ & $\begin{array}{c}0.042 \\
{[0.110]}\end{array}$ & $\begin{array}{l}-0.226 * \\
{[0.121]}\end{array}$ & $\begin{array}{c}0.190 \\
{[0.194]}\end{array}$ & $\begin{array}{c}-0.179 * * \\
{[0.085]}\end{array}$ & $\begin{array}{c}-0.270 * * \\
{[0.120]}\end{array}$ \\
\hline Leveraget-4 & $\begin{array}{c}-0.009 \\
{[0.007]}\end{array}$ & $\begin{array}{c}0.007 * * \\
{[0.003]}\end{array}$ & $\begin{array}{c}0.001 \\
{[0.004]}\end{array}$ & $\begin{array}{c}-0.004 \\
{[0.005]}\end{array}$ & $\begin{array}{c}0.007 * * * \\
{[0.002]}\end{array}$ & $\begin{array}{c}0.001 \\
{[0.002]}\end{array}$ \\
\hline Z-Score $t_{-4}$ & $\begin{array}{c}0.092 \\
{[0.072]}\end{array}$ & $\begin{array}{c}0.293 * * * \\
{[0.039]}\end{array}$ & $\begin{array}{c}-0.030 \\
{[0.037]}\end{array}$ & $\begin{array}{c}0.045 \\
{[0.065]}\end{array}$ & $\begin{array}{c}0.269 * * * \\
{[0.027]}\end{array}$ & $\begin{array}{c}0.029 \\
{[0.026]}\end{array}$ \\
\hline Firm FE & YES & YES & YES & YES & YES & YES \\
\hline Bank FE & YES & YES & YES & YES & YES & YES \\
\hline Year FE & YES & YES & YES & YES & YES & YES \\
\hline Observations & 64332 & 66211 & 48920 & 111250 & 115126 & 88274 \\
\hline R-squared & 0.002 & 0.021 & 0.020 & 0.005 & 0.049 & 0.068 \\
\hline No. Firms & 2549 & 2393 & 2268 & 2593 & 2414 & 2333 \\
\hline No. Issuers & 90 & 81 & 86 & 90 & 81 & 86 \\
\hline
\end{tabular}




\section{Table 9. Firm Level Analysis}

\section{Effects of the First Minibond Issuance on Lending Rates}

This table presents the results of the difference-in-differences regression for the changes in lending rates at the firm level after the issuance of minibonds. The treatment corresponds to the first issuance of a minibond. The control sample includes ex-ante comparable non-issuer firms identified on the basis of a coarsened exact matching based on ex-ante firm level characteristics. The control group is selected in each year, and each firm in the control group is assigned the same time of event of the matched treated firms in that year. The regression includes firm and year fixed effects. Given the inclusion of firm and time fixed effects, the coefficient for the interaction between the first minibond issuance (Minibond) and the post-issuance dummy (Post) defines the average treatment effect of the first issuance on lending rates at the firm level, for different categories of credit contracts (credit lines, advances, long-term loans) and for the overall bank debt, as well as on the interest rates for the total financial debt used (including bank debt and bond issuances). We consider two quarters before the first issuance by firm $(\mathrm{Post}=0)$, against the quarter of the issuance and the following two quarters (dummy Post=1). The issuance period considered in the estimates is between the fourth quarter of 2012 and the end of 2016; the overall sample period consider data between June 2012 up until June 2017. The lending rates are expressed in percent rates. While Col. 1, 3, 5, 7 and 9 correspond to the specifications with the fixed effects and the diff-in-diff interaction term, Col. 2, 4, 6, 8 and 10 report also the one-year lagged firm level control variables (total assets, leverage and Z-Score). Standard errors are clustered at firm level. Regressions are weighted with CEM strata weights. $* * *, * *, *$ indicate, respectively, statistical significance at $1,5,10$ percent level.

\begin{tabular}{|c|c|c|c|c|c|c|c|c|c|c|}
\hline \multirow{3}{*}{$\begin{array}{c}\text { Minibond * } \\
\text { Post }\end{array}$} & (1) & (2) & (3) & (4) & $(5)$ & $(6)$ & (7) & $(8)$ & (9) & $(10)$ \\
\hline & \multicolumn{2}{|c|}{ Credit lines } & \multicolumn{2}{|c|}{ Advances } & \multicolumn{2}{|c|}{ Long-Term } & \multicolumn{2}{|c|}{$\begin{array}{c}\text { Overall } \\
\text { bank loans }\end{array}$} & \multicolumn{2}{|c|}{$\begin{array}{c}\text { Total Financial } \\
\text { Debt }\end{array}$} \\
\hline & $\begin{array}{r}0.606 \\
{[0.424]}\end{array}$ & $\begin{array}{r}0.535 \\
{[0.432]}\end{array}$ & $\begin{array}{l}-0.285 * * * \\
{[0.102]}\end{array}$ & $\begin{array}{l}-0.267 * * * \\
{[0.103]}\end{array}$ & $\begin{array}{l}-0.390 * * * \\
{[0.139]}\end{array}$ & $\begin{array}{l}-0.400 * * * \\
{[0.139]}\end{array}$ & $\begin{array}{c}-0.499 * \\
{[0.294]}\end{array}$ & $\begin{array}{l}-0.472 * \\
{[0.285]}\end{array}$ & $\begin{array}{c}0.067 \\
{[0.293]}\end{array}$ & $\begin{array}{c}0.092 \\
{[0.283]}\end{array}$ \\
\hline $\begin{array}{l}\text { Ln (Total } \\
\text { Assetst-4) }\end{array}$ & & $\begin{array}{c}1.202 * * \\
{[0.595]}\end{array}$ & & $\begin{array}{c}-0.235 \\
{[0.357]}\end{array}$ & & $\begin{array}{c}0.153 \\
{[0.389]}\end{array}$ & & $\begin{array}{c}-0.476 \\
{[0.549]}\end{array}$ & & $\begin{array}{c}-0.443 \\
{[0.550]}\end{array}$ \\
\hline Leverage $_{t-4}$ & & $\begin{array}{c}-0.025 * * * \\
{[0.009]}\end{array}$ & & $\begin{array}{c}0.001 \\
{[0.004]}\end{array}$ & & $\begin{array}{c}0.007 * \\
{[0.004]}\end{array}$ & & $\begin{array}{c}0.020^{*} \\
{[0.012]}\end{array}$ & & $\begin{array}{c}0.020^{*} \\
{[0.012]}\end{array}$ \\
\hline Z-Scoret-4 & & $\begin{array}{c}0.118 \\
{[0.207]}\end{array}$ & & $\begin{array}{c}0.015 \\
{[0.052]}\end{array}$ & & $\begin{array}{c}0.090 \\
{[0.060]}\end{array}$ & & $\begin{array}{c}0.065 \\
{[0.105]}\end{array}$ & & $\begin{array}{r}0.078 \\
{[0.104]}\end{array}$ \\
\hline Firm FE & YES & YES & YES & YES & YES & YES & YES & YES & YES & YES \\
\hline Year FE & YES & YES & YES & YES & YES & YES & YES & YES & YES & YES \\
\hline Observations & 12265 & 12265 & 11650 & 11650 & 11079 & 11079 & 12694 & 12694 & 12694 & 12694 \\
\hline R-Squared & 0.001 & 0.004 & 0.058 & 0.059 & 0.083 & 0.089 & 0.003 & 0.003 & 0.002 & 0.003 \\
\hline No. Firms & 2565 & 2565 & 2399 & 2399 & 2309 & 2309 & 2585 & 2585 & 2585 & 2585 \\
\hline No. Issuers & 90 & 90 & 82 & 82 & 87 & 87 & 90 & 90 & 90 & 90 \\
\hline
\end{tabular}


Table 10. Firm Level Analysis

\section{Effects of the First Minibond Issuance on Lending Rates (longer post-issuance period)}

This table presents the results of the difference-in-differences regression for the changes in lending rates at the firm level after the issuance of minibonds. The treatment corresponds to the first issuance of a minibond. The control sample includes ex-ante comparable non-issuer firms identified on the basis of a coarsened exact matching based on ex-ante firm level characteristics. The control group is selected in each year, and each firm in the control group is assigned the same time of event of the matched treated firms in that year. The regression includes firm and year fixed effects. Given the inclusion of firm and time fixed effects, the coefficient for the interaction between the first minibond issuance (Minibond) and the post-issuance dummy (Post) defines the average treatment effect issuance on lending rates at the firm level, for different categories of credit contracts (credit lines, advances, long-term loans) and for the overall bank debt, as well as on the interest rates for the total financial debt used (including bank debt and bond issuances). We consider two quarters before the first issuance by firm $(\mathrm{Post}=0)$, against the quarter of the issuance and the following six quarters (dummy Post=1). The issuance period considered in the estimates is between the fourth quarter of 2012 and the end of 2016; the overall sample period consider data between June 2012 up until June 2018. The lending rates are expressed in percent rates. While Col. 1, 3, 5, 7 and 9 correspond to the specifications with the fixed effects and the diff-in-diff interaction term, Col. 2, 4, 6, 8 and 10 report also the one-year lagged firm level control variables (total assets, leverage and Z-Score). Standard errors are clustered at firm level. Regressions are weighted with CEM strata weights. $* * *, * *, *$ indicate, respectively, statistical significance at $1,5,10$ percent level.

\begin{tabular}{|c|c|c|c|c|c|c|c|c|c|c|}
\hline & (1) & (2) & (3) & (4) & (5) & (6) & (7) & (8) & (9) & (10) \\
\hline & \multicolumn{2}{|c|}{ Credit lines } & \multicolumn{2}{|c|}{ Advances } & \multicolumn{2}{|c|}{ Long-Term } & \multicolumn{2}{|c|}{$\begin{array}{c}\text { Overall } \\
\text { bank loans }\end{array}$} & \multicolumn{2}{|c|}{$\begin{array}{c}\text { Total Financial } \\
\text { Debt }\end{array}$} \\
\hline Minibond * Post & $\begin{array}{c}0.611 \\
{[0.478]}\end{array}$ & $\begin{array}{c}0.572 \\
{[0.483]}\end{array}$ & $\begin{array}{c}-0.379 * * * \\
{[0.131]}\end{array}$ & $\begin{array}{c}-0.355^{* * *} \\
{[0.129]}\end{array}$ & $\begin{array}{c}-0.482 * * * \\
{[0.160]}\end{array}$ & $\begin{array}{c}-0.471 * * * \\
{[0.158]}\end{array}$ & $\begin{array}{c}-0.414 * * \\
{[0.199]}\end{array}$ & $\begin{array}{c}-0.392 * * \\
{[0.194]}\end{array}$ & $\begin{array}{c}0.230 \\
{[0.206]}\end{array}$ & $\begin{array}{c}0.250 \\
{[0.200]}\end{array}$ \\
\hline Ln (Total Assetst-4) & & $\begin{array}{c}0.472 \\
{[0.495]}\end{array}$ & & $\begin{array}{c}-0.171 \\
{[0.179]}\end{array}$ & & $\begin{array}{l}-0.105 \\
{[0.236]}\end{array}$ & & $\begin{array}{c}-0.247 \\
{[0.290]}\end{array}$ & & $\begin{array}{l}-0.224 \\
{[0.290]}\end{array}$ \\
\hline Leverage $t-4$ & & -0.007 & & -0.000 & & 0.002 & & 0.002 & & 0.002 \\
\hline Z-Scoret-4 & & $\begin{array}{c}{[0.008]} \\
-0.091 \\
{[0.175]}\end{array}$ & & $\begin{array}{c}{[0.003]} \\
0.075^{* *} \\
{[0.037]}\end{array}$ & & $\begin{array}{c}{[0.003]} \\
0.139 * * * \\
{[0.044]}\end{array}$ & & $\begin{array}{c}{[0.005]} \\
0.053 \\
{[0.144]}\end{array}$ & & $\begin{array}{c}{[0.005]} \\
0.055 \\
{[0.143]}\end{array}$ \\
\hline Firm FE & $\begin{array}{l}\text { YES } \\
\text { YES }\end{array}$ & $\begin{array}{l}\text { YES } \\
\text { YFS }\end{array}$ & $\begin{array}{l}\text { YES } \\
\text { YES }\end{array}$ & $\begin{array}{l}\text { YES } \\
\text { YES }\end{array}$ & $\begin{array}{l}\text { YES } \\
\text { YES }\end{array}$ & $\begin{array}{l}\text { YES } \\
\text { YES }\end{array}$ & $\begin{array}{l}\text { YES } \\
\text { YES }\end{array}$ & $\begin{array}{l}\text { YES } \\
\text { YES }\end{array}$ & $\begin{array}{l}\text { YES } \\
\text { YES }\end{array}$ & $\begin{array}{l}\text { YES } \\
\text { YES }\end{array}$ \\
\hline Year FE & YES & YES & YES & YES & YES & YES & YES & YES & YES & YES \\
\hline Observations & 20862 & 20862 & 20571 & 20571 & 19981 & 19981 & 22558 & 22558 & 22558 & 22558 \\
\hline R-Squared & 0.010 & 0.011 & 0.148 & 0.151 & 0.162 & 0.169 & 0.003 & 0.003 & 0.003 & 0.003 \\
\hline No. Firms & 2518 & 2518 & 2419 & 2419 & 2365 & 2365 & 2601 & 2601 & 2601 & 2601 \\
\hline No. Issuers & 89 & 89 & 82 & 82 & 87 & 87 & 90 & 90 & 90 & 90 \\
\hline
\end{tabular}




\section{Table 11. Firm Level Analysis}

\section{Effects of the First Minibond Issuance on Credit Volumes}

This table presents the results of the difference-in-differences regression for the changes in lending volumes at the firm level after the issuance of minibonds. The treatment corresponds to the first issuance of a minibond. The control sample includes ex-ante comparable non-issuer firms identified on the basis of a coarsened exact matching based on ex-ante firm level characteristics. The control group is selected in each year, and each firm in the control group is assigned the same time of event of the matched treated firms in that year. The regression includes firm and year fixed effects. Given the inclusion of firm and time fixed effects, the coefficient for the interaction between the first minibond issuance (Minibond) and the post-issuance dummy (Post) defines the average treatment effect of the first issuance on lending volumes at the firm level, respectively for used and granted bank credit, for the ratio between used and granted bank credit (for all the types of credit contracts), as well as for the total financial debt used (including bank credit, debt from other financial intermediaries and minibond issuances). We consider two quarters before the first issuance by firm (Post=0), against the quarter of the issuance and the following two quarters (dummy Post=1). The issuance period considered in the estimates is between the fourth quarter of 2012 and the end of 2016; the overall sample period consider data between June 2012 up until June 2017. While Col. 1, 3, 5 and 7 correspond to the specifications with the fixed effects and the diff-in-diff interaction term, Col. 2, 4, 6 and 8 report also the one-year lagged firm level control variables (total assets, leverage and Z-Score). Standard errors are clustered at firm level. Regressions are weighted with CEM strata weights. ***, **,* indicate, respectively, statistical significance at 1, 5, 10 percent level.

\begin{tabular}{|c|c|c|c|c|c|c|c|c|c|}
\hline \multirow{3}{*}{ Minibond * Post } & (1) & $(2)$ & (3) & (4) & $(5)$ & $(6)$ & $(7)$ & $(8)$ & \multirow{3}{*}{$\begin{array}{c}(9) \\
\text { Financial } \\
\text { debt/ } \\
\text { Assets } \\
0.098 * * * \\
{[0.016]}\end{array}$} \\
\hline & \multicolumn{2}{|c|}{ Credit Used } & \multicolumn{2}{|c|}{ Credit Granted } & \multicolumn{2}{|c|}{ Used / Granted } & \multicolumn{2}{|c|}{$\begin{array}{l}\text { Total Financial } \\
\text { Debt Used }\end{array}$} & \\
\hline & $\begin{array}{c}-0.341 * * * \\
{[0.111]}\end{array}$ & $\begin{array}{c}-0.360 * * * \\
{[0.111]}\end{array}$ & $\begin{array}{l}-0.086 \\
{[0.066]}\end{array}$ & $\begin{array}{l}-0.105 \\
{[0.066]}\end{array}$ & $\begin{array}{c}-0.105 * * * \\
{[0.018]}\end{array}$ & $\begin{array}{c}-0.106^{* * *} \\
{[0.018]}\end{array}$ & $\begin{array}{c}0.404 * * * \\
{[0.060]}\end{array}$ & $\begin{array}{c}0.383 * * * \\
{[0.057]}\end{array}$ & \\
\hline Ln (Total Assetst-4) & & $\begin{array}{c}0.221 * * \\
{[0.097]}\end{array}$ & & $\begin{array}{l}0.207 * * \\
{[0.082]}\end{array}$ & & $\begin{array}{c}0.020 \\
{[0.023]}\end{array}$ & & $\begin{array}{c}0.259 * * * \\
{[0.098]}\end{array}$ & \\
\hline Leverage $_{t-4}$ & & $\begin{array}{l}0.005^{*} \\
{[0.003]}\end{array}$ & & $\begin{array}{l}0.004 * * \\
{[0.002]}\end{array}$ & & $\begin{array}{l}-0.000 \\
{[0.000]}\end{array}$ & & $\begin{array}{l}0.004 * \\
{[0.003]}\end{array}$ & \\
\hline Z-Score ${ }_{t-4}$ & & $\begin{array}{c}0.034 \\
{[0.039]}\end{array}$ & & $\begin{array}{l}-0.019 \\
{[0.020]}\end{array}$ & & $\begin{array}{c}0.016^{* *} \\
{[0.007]}\end{array}$ & & $\begin{array}{c}0.036 \\
{[0.028]}\end{array}$ & \\
\hline Firm FE & YES & YES & YES & YES & YES & YES & YES & YES & YES \\
\hline Year FE & YES & YES & YES & YES & YES & YES & YES & YES & YES \\
\hline Observations & 13609 & 13609 & 13609 & 13609 & 13494 & 13494 & 13624 & 13624 & 13624 \\
\hline R-Squared & 0.006 & 0.009 & 0.007 & 0.015 & 0.013 & 0.018 & 0.006 & 0.011 & 0.006 \\
\hline No. Firms & 2744 & 2744 & 2744 & 2744 & 2729 & 2729 & 2745 & 2745 & 2745 \\
\hline No. Issuers & 91 & 91 & 91 & 91 & 91 & 91 & 91 & 91 & 91 \\
\hline
\end{tabular}




\section{Table 12. Firm Level Analysis}

\section{Effects of the First Minibond Issuance on Credit Volumes (longer post-issuance period)}

This table presents the results of the difference-in-differences regression for the changes in lending volumes at the firm level after the issuance of minibonds. The treatment corresponds to the first issuance of a minibond. The control sample includes ex-ante comparable non-issuer firms identified on the basis of a coarsened exact matching based on ex-ante firm level characteristics. The control group is selected in each year, and each firm in the control group is assigned the same time of event of the matched treated firms in that year. The regression includes firm and year fixed effects. Given the inclusion of firm and time fixed effects, the coefficient for the interaction between the first minibond issuance (Minibond) and the post-issuance dummy (Post) defines the average treatment effect of the first issuance on lending volumes at the firm level, respectively for used and granted bank credit, for the ratio between used and granted bank credit (for all the types of credit contracts), as well as for the total financial debt used (including bank credit, debt from other financial intermediaries and minibond issuances). We consider two quarters before the first issuance by firm (Post=0), against the quarter of the issuance and the following six quarters (dummy Post=1). The issuance period considered in the estimates is between the fourth quarter of 2012 and the end of 2016; the overall sample period consider data between June 2012 up until June 2018. While Col. 1, 3, 5 and 7 correspond to the specifications with the fixed effects and the diff-in-diff interaction term, Col. 2, 4, 6 and 8 report also the one-year lagged firm level control variables (total assets, leverage and Z-Score). Standard errors are clustered at firm level. Regressions are weighted with CEM strata weights. ***,**,* indicate, respectively, statistical significance at 1, 5, 10 percent level.

\begin{tabular}{|c|c|c|c|c|c|c|c|c|c|}
\hline \multirow[b]{3}{*}{ Minibond * Post } & $(1)$ & $(2)$ & (3) & (4) & $(5)$ & $(6)$ & $(7)$ & $(8)$ & (9) \\
\hline & \multicolumn{2}{|c|}{ Credit Used } & \multicolumn{2}{|c|}{ Credit Granted } & \multicolumn{2}{|c|}{ Used / Granted } & \multicolumn{2}{|c|}{$\begin{array}{c}\text { Total Financial } \\
\text { Debt Used }\end{array}$} & $\begin{array}{c}\text { Financial } \\
\text { debt/ total } \\
\text { assets }\end{array}$ \\
\hline & $\begin{array}{c}-0.263 * * \\
{[0.115]}\end{array}$ & $\begin{array}{c}-0.349 * * * \\
{[0.114]}\end{array}$ & $\begin{array}{c}-0.034 \\
{[0.058]}\end{array}$ & $\begin{array}{c}-0.097 * \\
{[0.058]}\end{array}$ & $\begin{array}{c}-0.092 * * * \\
{[0.018]}\end{array}$ & $\begin{array}{c}-0.099 * * * \\
{[0.018]}\end{array}$ & $\begin{array}{c}0.475 * * * \\
{[0.063]}\end{array}$ & $\begin{array}{c}0.392 * * * \\
{[0.056]}\end{array}$ & $\begin{array}{c}0.102 * * * \\
{[0.016]}\end{array}$ \\
\hline Ln (Total Assetst-4) & & $\begin{array}{c}0.549 * * * \\
{[0.115]}\end{array}$ & & $\begin{array}{c}0.419 * * * \\
{[0.089]}\end{array}$ & & $\begin{array}{c}0.051 * * * \\
{[0.016]}\end{array}$ & & $\begin{array}{c}0.528 * * * \\
{[0.097]}\end{array}$ & \\
\hline Leverage $_{t-4}$ & & $\begin{array}{c}0.005 * * \\
{[0.002]}\end{array}$ & & $\begin{array}{c}0.003 * * \\
{[0.002]}\end{array}$ & & $\begin{array}{c}0.000 \\
{[0.000]}\end{array}$ & & $\begin{array}{c}0.005 * * * \\
{[0.001]}\end{array}$ & \\
\hline Z-Score ${ }_{t-4}$ & & $\begin{array}{c}-0.056 \\
{[0.044]}\end{array}$ & & $\begin{array}{c}-0.046^{* *} \\
{[0.021]}\end{array}$ & & $\begin{array}{c}0.015 * * * \\
{[0.005]}\end{array}$ & & $\begin{array}{c}0.002 \\
{[0.024]}\end{array}$ & \\
\hline Firm FE & YES & YES & YES & YES & YES & YES & YES & YES & YES \\
\hline Year FE & YES & YES & YES & YES & YES & YES & YES & YES & YES \\
\hline Observations & 24283 & 24283 & 24283 & 24283 & 24021 & 24021 & 24322 & 24322 & 24322 \\
\hline R-Squared & 0.006 & 0.021 & 0.006 & 0.028 & 0.012 & 0.022 & 0.006 & 0.026 & 0.004 \\
\hline No. Firms & 2745 & 2745 & 2745 & 2745 & 2731 & 2731 & 2745 & 2745 & 2745 \\
\hline No. Issuers & 91 & 91 & 91 & 91 & 91 & 91 & 91 & 91 & 91 \\
\hline
\end{tabular}




\section{Table 13. Firm Level Analysis}

\section{Effects of the First Minibond Issuance on Firm Ex-post Outcomes}

This table presents the results of the difference-in-differences estimation for the ex-post changes in the balance sheet and the performance of issuer firms after the first issuance of minibonds. We explore whether and how issuer firms changed their balance sheet composition, turnover and profitability, in the two years after the first issuance. The treatment corresponds to the first issuance of a minibond. The control sample includes ex-ante comparable non-issuer firms identified on the basis of a coarsened exact matching based on ex-ante firm level characteristics. The Minibond dummy is equal to 1 for the firms issuing minibonds, while the Post dummy is equal to 1 for the year following the minibond issuance. Given the inclusion of time fixed effects, the coefficient for the interaction between the first minibond issuance (Minibond) and the post-issuance dummy (Post) defines the average treatment effect of the first issuance on firm balance sheet and performance. We consider each dependent variable one year before the first issuance $(\mathrm{Post}=0)$, against the two years after the issuance $(\mathrm{Post}=1)$. The issuance period considered in the estimates is between the fourth quarter of 2012 and the fourth quarter of 2016; the overall sample period for firm balance sheets consider annual data from 2012 to 2017. Standard errors are clustered at firm level. Regressions are weighted with CEM strata weights. $* * *, * *, *$ indicate, respectively, statistical significance at $1,5,10$ percent level.

\begin{tabular}{|c|c|c|c|c|c|c|c|}
\hline \multicolumn{8}{|c|}{ ASSETS } \\
\hline & (1) & (2) & (3) & (4) & (5) & (6) & (7) \\
\hline VARIABLES & $\begin{array}{l}\text { Ln total } \\
\text { assets }\end{array}$ & $\begin{array}{l}\text { Ln total } \\
\text { fixed assets }\end{array}$ & $\begin{array}{c}\text { Ln } \\
\text { tangible } \\
\text { fixed assets }\end{array}$ & $\begin{array}{l}\text { Ln } \\
\text { intangible } \\
\text { fixed assets }\end{array}$ & $\begin{array}{l}\text { Total fixed } \\
\text { assets/ Total } \\
\text { assets }\end{array}$ & $\begin{array}{c}\text { Tangible } \\
\text { fixed assets/ } \\
\text { Total assets }\end{array}$ & $\begin{array}{r}\text { Intangible } \\
\text { fixed assets } / \\
\text { Total assets }\end{array}$ \\
\hline Minibond * Post & $\begin{array}{c}0.186 * * * \\
{[0.037]}\end{array}$ & $\begin{array}{l}0.148 * * \\
{[0.071]}\end{array}$ & $\begin{array}{c}0.066 \\
{[0.061]}\end{array}$ & $\begin{array}{c}0.247 * * \\
{[0.120]}\end{array}$ & $\begin{array}{c}-0.002 \\
{[0.009]}\end{array}$ & $\begin{array}{c}-0.005 \\
{[0.007]}\end{array}$ & $\begin{array}{c}0.003 \\
{[0.007]}\end{array}$ \\
\hline Firm FE & YES & YES & YES & YES & YES & YES & YES \\
\hline Year FE & YES & YES & YES & YES & YES & YES & YES \\
\hline Observations & 7287 & 7251 & 7220 & 6832 & 7287 & 7287 & 7287 \\
\hline R-squared & 0.028 & 0.011 & 0.010 & 0.019 & 0.015 & 0.009 & 0.015 \\
\hline No. Firms & 2722 & 2719 & 2713 & 2632 & 2722 & 2722 & 2722 \\
\hline No. Issuers & 85 & 85 & 85 & 82 & 85 & 85 & 85 \\
\hline
\end{tabular}

\begin{tabular}{|c|c|c|c|c|c|c|}
\hline & \multicolumn{3}{|c|}{ LIABILITIES } & \multicolumn{3}{|c|}{ TURNOVER AND PROFITABILITY } \\
\hline & $(8)$ & (9) & $(10)$ & $(11)$ & $(12)$ & $(13)$ \\
\hline VARIABLES & $\begin{array}{c}\text { Bank debt/ } \\
\text { Total } \\
\text { financial } \\
\text { debt } \\
\end{array}$ & $\begin{array}{c}\text { Total } \\
\text { financial } \\
\text { debt/ } \\
\text { Turnover }\end{array}$ & Leverage & Ln turnover & RoA & $\mathbf{R o E}$ \\
\hline Minibond * Post & $\begin{array}{c}-0.233 * * * \\
{[0.028]}\end{array}$ & $\begin{array}{c}0.249 \\
{[0.158]}\end{array}$ & $\begin{array}{c}0.102 * * * \\
{[0.019]}\end{array}$ & $\begin{array}{c}0.049 \\
{[0.060]}\end{array}$ & $\begin{array}{c}-2.487 * * * \\
{[0.794]}\end{array}$ & $\begin{array}{c}-9.714 \\
{[6.205]}\end{array}$ \\
\hline Firm FE & YES & YES & YES & YES & YES & YES \\
\hline Year FE & YES & YES & YES & YES & YES & YES \\
\hline Observations & 7077 & 7269 & 7287 & 7269 & 7287 & 7281 \\
\hline R-squared & 0.050 & 0.041 & 0.041 & 0.010 & 0.009 & 0.008 \\
\hline No. Firms & 2701 & 2721 & 2722 & 2721 & 2722 & 2722 \\
\hline No Issuers & 85 & 85 & 85 & 85 & 85 & 85 \\
\hline
\end{tabular}


Table 14. Robustness Checks: Firm-Bank Level Analysis

\section{Effects of the First Minibond Issuance on Lending Rates and Volumes}

This table presents the results of some robustness checks for the difference-in-differences regression on the changes in lending rates and volumes at the firm-bank level after the issuance of minibonds. In panel A we focus on a subsample of minibonds with an original maturity of at least 2 years. In panel $\mathrm{B}$, we consider a subsample of minibonds with an issuance amount of at most EUR 20 million. In panel C, we focus on a subsample of firms with a turnover amount of at most EUR 50 million (and therefore classified as medium or small enterprises). In Panel D, we consider a subsample of firms located outside Lombardy, where the Italian Stock Exchange "Borsa Italiana" is placed (note that "Borsa Italiana" administers the ExtraMot Pro Platform for the listing of minibonds). The treatment corresponds to the first issuance of a minibond. The control sample includes ex-ante comparable non- issuer firms identified on the basis of a coarsened exact matching based on ex-ante firm level characteristics. The control group is selected in each year, and each firm in the control group is assigned the same time of event of the matched treated firms in that year. The regressions include firm, bank and year fixed effects. The coefficient for the interaction between the first minibond issuance (Minibond) and the post-issuance dummy (Post) defines the average treatment effect on the lending rates for advances and long-term loans, and on credit volumes for used and granted bank credit, for the ratio between used and granted bank credit (for all the types of credit contracts). We consider two quarters before the first issuance by firm $($ Post $=0)$, against the quarter of the issuance and the following two quarters (dummy Post $=1)$. The issuance period considered in the estimates is between the fourth quarter of 2012 and the end of 2016; the overall sample period consider data between June 2012 up until June 2017. The lending rates are expressed in percent rates. The regression specification includes also the one-year lagged firm level control variables (total assets, leverage and Z-Score). Standard errors are clustered at firm level. Regressions are weighted with CEM strata weights. ***, **,* indicate, respectively, statistical significance at $1,5,10$ percent level.

Panel A. Bond Maturity: Above or Equal to Two Years

\begin{tabular}{l|cc|ccc}
\hline \multirow{2}{*}{} & \multicolumn{2}{|c|}{ Lending Rates } & \multicolumn{3}{c}{ Lending Volumes } \\
\cline { 2 - 6 } & Advances & Long-Term & Credit Used & Credit Granted & Used / Granted \\
\hline Minibond * Post & $-0.298^{* * *}$ & $-0.191^{* * *}$ & $-0.625^{* * *}$ & $-0.121^{*}$ & $-0.114^{* * *}$ \\
& {$[0.112]$} & {$[0.062]$} & {$[0.157]$} & {$[0.066]$} & {$[0.020]$} \\
Firm Controls & & & & YES \\
Firm FE & YES & YES & YES & YES & YES \\
Bank FE & YES & YES & YES & YES & YES \\
Year FE & YES & YES & YES & YES & YES \\
Observations & YES & YES & YES & 153745 & 79409 \\
R-Squared & 54407 & 39800 & 81519 & 0.000 & 0.003 \\
No. Firms & 0.012 & 0.014 & 0.002 & 2253 & 2235 \\
No. Issuers & 1971 & 1860 & 2246 & 74 & 73 \\
\hline
\end{tabular}

Panel B. Bond Issuance Amount: Below or Equal to EUR 20 Million

\begin{tabular}{l|cc|ccc}
\hline \multirow{2}{*}{} & \multicolumn{2}{|c|}{ Lending Rates } & \multicolumn{3}{c}{ Lending Volumes } \\
\cline { 2 - 6 } & Advances & Long-Term & Credit Used & Credit Granted & Used / Granted \\
\hline Minibond * Post & $-0.319^{* * *}$ & $-0.274 * * *$ & $-0.269^{* * *}$ & 0.037 & $-0.069^{* * *}$ \\
& {$[0.104]$} & {$[0.079]$} & {$[0.080]$} & {$[0.050]$} & {$[0.014]$} \\
Firm Controls & & & & YES \\
Firm FE & YES & YES & YES & YES & YES \\
Bank FE & YES & YES & YES & YES & YES \\
Year FE & YES & YES & YES & YES & YES \\
Observations & YES & YES & YES & 173540 & 89665 \\
R-Squared & 62643 & 46540 & 92030 & 0.000 & 0.002 \\
No. Firms & 0.012 & 0.014 & 0.002 & 2534 & 2510 \\
No. Issuers & 2224 & 2127 & 2520 & 73 & 73 \\
\hline
\end{tabular}


Panel C. Firm Size: Turnover Below or Equal to EUR 50 Million

\begin{tabular}{l|cc|ccc}
\hline \multirow{2}{*}{} & \multicolumn{2}{|c|}{ Lending Rates } & \multicolumn{3}{c}{ Lending Volumes } \\
\cline { 2 - 6 } & Advances & Long-Term & Credit Used & Credit Granted & Used / Granted \\
\hline Minibond * Post & $-0.162^{*}$ & $-0.316^{* * *}$ & $-0.232^{* *}$ & -0.005 & $-0.065^{* * *}$ \\
& {$[0.089]$} & {$[0.121]$} & {$[0.102]$} & {$[0.055]$} & {$[0.017]$} \\
Firm Controls & & & & YES \\
Firm FE & YES & YES & YES & YES & YES \\
Bank FE & YES & YES & YES & YES & YES \\
Year FE & YES & YES & YES & YES & YES \\
Ybservations & YES & YES & YES & & 67080 \\
R-Squared & 47434 & 34194 & 68857 & 0.000 & 0.001 \\
No. Firms & 0.007 & 0.014 & 0.001 & 2060 & 2038 \\
No. Issuers & 1807 & 1724 & 2046 & 55 & 54 \\
\hline
\end{tabular}

Panel D. Firms located outside Lombardy (Less Proximity to the Italian Stock Exchange)

\begin{tabular}{l|cc|ccc}
\hline \multirow{2}{*}{} & \multicolumn{2}{|c|}{ Lending Rates } & \multicolumn{3}{c}{ Lending Volumes } \\
\cline { 2 - 6 } & Advances & Long-Term & Credit Used & Credit Granted & Used / Granted \\
\hline Minibond * Post & $-0.312^{* * *}$ & $-0.295^{* * *}$ & $-0.628^{* * *}$ & -0.054 & $-0.116^{* * *}$ \\
& {$[0.081]$} & {$[0.083]$} & {$[0.170]$} & {$[0.083]$} & {$[0.022]$} \\
Firm Controls & & & & YES \\
Firm FE & YES & YES & YES & YES & YES \\
Bank FE & YES & YES & YES & YES & YES \\
Year FE & YES & YES & YES & YES & YES \\
YbS & YES & YES & & 57413 \\
R-Squared & & & & 112969 & 0.007 \\
No. Firms & 38021 & 28411 & 59122 & 0.002 & 1579 \\
No. Issuers & 0.022 & 0.015 & 0.003 & 1590 & 69 \\
\hline
\end{tabular}




\section{Table 15. Robustness Checks: Firm Level Analysis}

\section{Effects of the First Minibond Issuance on Lending Rates and Volumes}

This table presents the results of some robustness checks for the difference-in-differences regression on the changes in lending rates and volumes at the firm level after the issuance of minibonds. In panel A we focus on a subsample of minibonds with an original maturity of at least 2 years. In panel B, we consider a subsample of minibonds with an issuance amount of at most EUR 20 million. In panel $\mathrm{C}$, we focus on a subsample of firms with a turnover amount of at most EUR 50 million (and therefore classified as medium or small enterprises). In Panel D, we consider a subsample of firms located outside Lombardy, where the Italian Stock Exchange "Borsa Italiana" is placed (note that "Borsa Italiana" administers the ExtraMot Pro Platform for the listing of minibonds). The treatment corresponds to the first issuance of a minibond. The control sample includes ex-ante comparable non-issuer firms identified on the basis of a coarsened exact matching based on ex-ante firm level characteristics. The control group is selected in each year, and each firm in the control group is assigned the same time of event of the matched treated firms in that year. The regressions include firm and year fixed effects. The coefficient for the interaction between the first minibond issuance (Minibond) and the post-issuance dummy (Post) defines the average treatment effect on the lending rates for advances and long-term loans, and on credit volumes for used and granted bank credit, for the ratio between used and granted bank credit (for all the types of credit contracts) and for the total financial debt used, including bank credit, debt from other financial intermediaries and minibond issuances. We consider two quarters before the first issuance by firm (Post $=0$ ), against the quarter of the issuance and the following two quarters (dummy Post $=1$ ). The issuance period considered in the estimates is between the fourth quarter of 2012 and the end of 2016; the overall sample period consider data between June 2012 up until June 2017. The lending rates are expressed in percent rates. The regression specification includes also the one-year lagged firm level control variables (total assets, leverage and Z-Score). Standard errors are clustered at firm level. Regressions are weighted with CEM strata weights. ***, **,* indicate, respectively, statistical significance at $1,5,10$ percent level.

Panel A. Bond Maturity: Above or Equal to Two Years

\begin{tabular}{|c|c|c|c|c|c|c|}
\hline & \multicolumn{2}{|c|}{ Lending Rates } & \multicolumn{3}{|c|}{ Lending Volumes } & \multirow{2}{*}{$\frac{\text { Debt }}{\text { Total Financial Debt }}$} \\
\hline & Advances & Long-Term & Credit Used & Credit Granted & Used / Granted & \\
\hline \multirow[t]{2}{*}{ Minibond $*$ Post } & $-0.263^{* *}$ & $-0.422 * * *$ & $-0.299 * * *$ & -0.113 & $-0.102 * * *$ & $0.393 * * *$ \\
\hline & {$[0.117]$} & {$[0.143]$} & {$[0.087]$} & [0.077] & {$[0.018]$} & {$[0.063]$} \\
\hline Firm Controls & YES & YES & YES & YES & YES & YES \\
\hline Firm FE & YES & YES & YES & YES & YES & YES \\
\hline Year FE & YES & YES & YES & YES & YES & YES \\
\hline Observations & 9606 & 9064 & 11152 & 11152 & 11062 & 11167 \\
\hline R-Squared & 0.058 & 0.100 & 0.008 & 0.016 & 0.017 & 0.012 \\
\hline No. Firms & 1975 & 1892 & 2246 & 2246 & 2235 & 2247 \\
\hline No. Issuers & 68 & 69 & 73 & 73 & 73 & 73 \\
\hline
\end{tabular}

Panel B. Bond Issuance Amount: Below or Equal to EUR 20 Million

\begin{tabular}{|c|c|c|c|c|c|c|}
\hline & \multicolumn{2}{|c|}{ Lending Rates } & \multicolumn{3}{|c|}{ Lending Volumes } & \multirow{2}{*}{$\frac{\text { Debt }}{\text { Total Financial Debt }}$} \\
\hline & Advances & Long-Term & Credit Used & Credit Granted & Used / Granted & \\
\hline \multirow[t]{2}{*}{ Minibond * Post } & $-0.276^{* *}$ & $-0.407 * *$ & $-0.080 *$ & $0.046^{*}$ & $-0.068 * * *$ & $0.311 * * *$ \\
\hline & {$[0.117]$} & {$[0.158]$} & {$[0.042]$} & {$[0.027]$} & {$[0.014]$} & {$[0.058]$} \\
\hline Firm Controls & YES & YES & YES & YES & YES & YES \\
\hline Firm FE & YES & YES & YES & YES & YES & YES \\
\hline Year FE & YES & YES & YES & YES & YES & YES \\
\hline Observations & 10853 & 10409 & 12498 & 12498 & 12408 & 12511 \\
\hline R-Squared & 0.069 & 0.088 & 0.011 & 0.016 & 0.018 & 0.013 \\
\hline No. Firms & 2228 & 2164 & 2520 & 2520 & 2510 & 2521 \\
\hline No. Issuers & 67 & 69 & 73 & 73 & 73 & 73 \\
\hline
\end{tabular}


Panel C. Firm Size: Turnover Below or Equal to EUR 50 Million

\begin{tabular}{|c|c|c|c|c|c|c|}
\hline & \multicolumn{2}{|c|}{ Lending Rates } & \multicolumn{3}{|c|}{ Lending Volumes } & \multirow{2}{*}{$\begin{array}{c}\text { Debt } \\
\text { Total Financial Debt }\end{array}$} \\
\hline & Advances & Long-Term & Credit Used & Credit Granted & Used / Granted & \\
\hline \multirow[t]{2}{*}{ Minibond * Post } & -0.102 & $-0.307 *$ & $-0.083^{*}$ & 0.026 & $-0.058 * * *$ & $0.408 * * *$ \\
\hline & {$[0.124]$} & [0.181] & {$[0.048]$} & {$[0.029]$} & {$[0.016]$} & {$[0.076]$} \\
\hline Firm Controls & YES & YES & YES & YES & YES & YES \\
\hline Firm FE & YES & YES & YES & YES & YES & YES \\
\hline Year FE & YES & YES & YES & YES & YES & YES \\
\hline Observations & 8828 & 8425 & 10150 & 10150 & 10090 & 10163 \\
\hline R-Squared & 0.041 & 0.088 & 0.016 & 0.020 & 0.020 & 0.019 \\
\hline No. Firms & 1809 & 1756 & 2046 & 2046 & 2038 & 2047 \\
\hline No. Issuers & 49 & 50 & 54 & 54 & 54 & 54 \\
\hline
\end{tabular}

Panel D. Firms located outside Lombardy (Less Proximity to the Italian Stock Exchange)

\begin{tabular}{|c|c|c|c|c|c|c|}
\hline & \multicolumn{2}{|c|}{ Lending Rates } & \multicolumn{3}{|c|}{ Lending Volumes } & \multirow{2}{*}{$\frac{\text { Debt }}{\text { Total Financial Debt }}$} \\
\hline & Advances & Long-Term & Credit Used & Credit Granted & Used / Granted & \\
\hline Minibond * Post & $\begin{array}{c}-0.257 * * \\
{[0.102]}\end{array}$ & $\begin{array}{c}-0.395 * * \\
{[0.164]}\end{array}$ & $\begin{array}{c}-0.267 * * * \\
{[0.087]}\end{array}$ & $\begin{array}{c}-0.060 \\
{[0.048]}\end{array}$ & $\begin{array}{c}-0.116^{* * *} \\
{[0.021]}\end{array}$ & $\begin{array}{c}0.313 * * * \\
{[0.046]}\end{array}$ \\
\hline Firm Controls & YES & YES & YES & YES & YES & YES \\
\hline Firm FE & YES & YES & YES & YES & YES & YES \\
\hline Year FE & YES & YES & YES & YES & YES & YES \\
\hline Observations & 6751 & 6507 & 7836 & 7836 & 7785 & 7836 \\
\hline R-Squared & 0.065 & 0.084 & 0.025 & 0.020 & 0.026 & 0.025 \\
\hline No. Firms & 1395 & 1361 & 1584 & 1584 & 1579 & 1584 \\
\hline No. Issuers & 63 & 66 & 69 & 69 & 69 & 69 \\
\hline
\end{tabular}




\section{Appendix A}

\section{Regressions Based on the Propensity Score Matching}

We conduct a further robustness check by estimating the difference-in-differences model on a control sample identified through propensity score matching, instead of exact coarsened matching.

We first compute the propensity score to issue minibonds based on ex-ante firm characteristics. We look at issuer firms in the year before the issuance and potential control firms in 2012, i.e., before the reform. We exclude ex-ante from the sample of potential controls the firms that differed from issuers in some prominent way: 1) those without lending relationships with banks; 2) those with an amount of total assets below EUR 1 million; 3) those with a rating very close to the default (Z-Score equal to 9 or 10 , as no issuer firm has this rating); 4) those with negative values of leverage; 5) those located in regions where there are not issuers; 6) those operating in financial services (as by construction we consider only non-financial corporations for the sample of issuer firms); 7) those having already issued debt securities on the capital market ${ }^{25}$.

The propensity score is estimated through a probit regression for the probability to issue minibonds, using as covariates the following variables: a) the log of total assets; $b$ ) the leverage and the square of leverage (to capture potential non-linearities); c) the Z-Score and the square of the Z-Score; d) dummies for geographical areas (North, Centre, South); e) industry-level dummies (agriculture and fishing, manufacturing, utilities and extraction, construction, services); f) dummies for the main bank.

We then implemented with two different matching algorithms. First, we employed a nearest neighbor matching with replacement, to select the nearest 30 controls for each treated firm. Second, we applied a radius matching with replacement with a radius of 0.00006 around the propensity score of each treated firm. These choices were aimed at obtaining a number of control firms similar to the one used in the Coarsened Exact Matching procedure.

The results for the two specifications are broadly similar. Table A.1 displays the estimates for the propensity score based on the nearest neighbor matching, while Table A.2 presents the results for the propensity score using the radius matching.

\footnotetext{
${ }^{25}$ The same exclusions were applied in the coarsened exact matching. Furthermore, we had already excluded, also from the sample of potential controls for the exact matching, those firms which had already issued debt securities.
} 


\section{Table A.1. Propensity Score Matching: Nearest Neighbor}

This table presents the results of the difference-in-differences regression for the changes in lending rates and volumes at the firm-bank level (panel A) and at the firm level (panel B) after the issuance of minibonds. The treatment corresponds to the first issuance of a minibond. The control sample includes ex-ante comparable non-issuer firms identified on the basis of a propensity score matching, which uses a nearest neighbour algorithm with replacement to select the nearest 30 controls for each treated firm based on ex-ante firm level characteristics. Each firm in the control group is assigned the same time of event of the corresponding matched treated firm. The regressions include bank, firm and year fixed effects in panel A, and firm and year fixed effects in panel B. The coefficient for the interaction between the first minibond issuance (Minibond) and the post-issuance dummy (Post) defines the average treatment effect on the lending rates for advances and long-term loans, and on credit volumes for used and granted bank credit, for the ratio between used and granted bank credit (for all the types of credit contracts) and for the total financial debt used, including bank credit, debt from other financial intermediaries and minibond issuances. We consider two quarters before the first issuance by firm $(\mathrm{Post}=0)$, against the quarter of the issuance and the following two quarters (dummy Post $=1)$. The issuance period considered in the estimates is between the fourth quarter of 2012 and the end of 2016; the overall sample period consider data between June 2012 up until June 2017. The lending rates are expressed in percent rates. The regression specification includes also the one-year lagged firm level control variables (total assets, leverage and ZScore). Standard errors are clustered at firm level. Regressions are weighted with CEM strata weights. ***, **,* indicate, respectively, statistical significance at 1, 5, 10 percent level.

Panel A. Firm-bank Level Analysis

\begin{tabular}{l|cc|ccc}
\hline & \multicolumn{2}{|c|}{ Lending Rates } & \multicolumn{3}{c}{ Lending Volumes } \\
\cline { 2 - 5 } Minibond * Post & Advances & Long-Term & Credit Used & Credit Granted & Used / Granted \\
& $-0.278^{* * *}$ & $-0.236^{* * *}$ & $-0.492^{* * *}$ & -0.098 & $-0.091^{* * *}$ \\
& {$[0.089]$} & {$[0.064]$} & {$[0.104]$} & {$[0.063]$} & {$[0.014]$} \\
& & & & & YES \\
Firm Controls & YES & YES & YES & YES & YES \\
Firm FE & YES & YES & YES & YES & YES \\
Bank FE & YES & YES & YES & YES & YES \\
Year FE & YES & YES & YES & & 106831 \\
& & & & 217405 & 0.002 \\
Observations & 60685 & 49149 & 110582 & 0.001 & 2837 \\
R-Squared & 0.010 & 0.011 & 0.001 & 2889 & 107 \\
No. Firms & 2199 & 2342 & 2850 & 109 & \\
No. Issuers & 94 & 101 & 107 & & \\
\hline
\end{tabular}

Panel B. Firm Level Analysis

\begin{tabular}{|c|c|c|c|c|c|c|}
\hline & \multicolumn{2}{|c|}{ Lending Rates } & \multicolumn{3}{|c|}{ Lending Volumes } & \multirow{2}{*}{$\begin{array}{c}\text { Debt } \\
\text { Total Financial Debt }\end{array}$} \\
\hline & Advances & Long-Term & Credit Used & Credit Granted & Used / Granted & \\
\hline Minibond * Post & $\begin{array}{c}-0.257^{* * *} \\
{[0.092]}\end{array}$ & $\begin{array}{c}-0.433 * * * \\
{[0.121]}\end{array}$ & $\begin{array}{c}-0.347 * * * \\
{[0.130]}\end{array}$ & $\begin{array}{c}-0.104 \\
{[0.064]}\end{array}$ & $\begin{array}{c}-0.097 * * * \\
{[0.019]}\end{array}$ & $\begin{array}{c}0.412 * * * \\
{[0.093]}\end{array}$ \\
\hline Firm Controls & YES & YES & YES & YES & YES & YES \\
\hline Firm FE & YES & YES & YES & YES & YES & YES \\
\hline Year FE & YES & YES & YES & YES & YES & YES \\
\hline Observations & 10679 & 11565 & 14110 & 14110 & 13979 & 14110 \\
\hline R-Squared & 0.040 & 0.050 & 0.012 & 0.015 & 0.011 & 0.012 \\
\hline No. Firms & 2216 & 2404 & 2850 & 2850 & 2837 & 2850 \\
\hline No. Issuers & 95 & 102 & 107 & 107 & 107 & 107 \\
\hline
\end{tabular}




\section{Table A.2. Propensity Score Matching: Radius Matching}

This table presents the results of the difference-in-differences regression for the changes in lending rates and volumes at the firm-bank level (panel A) and at the firm level (panel B) after the issuance of minibonds. The treatment corresponds to the first issuance of a minibond. The control sample includes ex-ante comparable non-issuer firms identified on the basis of a propensity score matching, which uses a radius matching with replacement to select the controls in the propensity score radius of 0.00006 for each treated firm based on ex-ante firm level characteristics. Each firm in the control group is assigned the same time of event of the corresponding matched treated firm. The regressions include bank, firm and year fixed effects in panel A, and firm and year fixed effects in panel B. The coefficient for the interaction between the first minibond issuance (Minibond) and the post-issuance dummy (Post) defines the average treatment effect on the lending rates for advances and long-term loans, and on credit volumes for used and granted bank credit, for the ratio between used and granted bank credit (for all the types of credit contracts) and for the total financial debt used, including bank credit, debt from other financial intermediaries and minibond issuances. We consider two quarters before the first issuance by firm $(\mathrm{Post}=0)$, against the quarter of the issuance and the following two quarters (dummy Post=1). The issuance period considered in the estimates is between the fourth quarter of 2012 and the end of 2016; the overall sample period consider data between June 2012 up until June 2017. The lending rates are expressed in percent rates. The regression specification includes also the one-year lagged firm level control variables (total assets, leverage and Z-Score). Standard errors are clustered at firm level. Regressions are weighted with CEM strata weights. $* * *, * *, *$ indicate, respectively, statistical significance at 1, 5, 10 percent level.

Panel A. Firm-bank Level Analysis

\begin{tabular}{l|cc|ccc}
\hline & \multicolumn{2}{|c|}{ Lending Rates } & \multicolumn{3}{c}{ Lending Volumes } \\
\cline { 2 - 6 } Minibond * Post & Advances & Long-Term & Credit Used & Credit Granted & Used / Granted \\
& $-0.267^{* * *}$ & $-0.283^{* * *}$ & $-0.457^{* * *}$ & -0.060 & $-0.095^{* * *}$ \\
& {$[0.096]$} & {$[0.072]$} & {$[0.098]$} & {$[0.060]$} & {$[0.015]$} \\
& & & & & YES \\
Firm Controls & YES & YES & YES & YES & YES \\
Firm FE & YES & YES & YES & YES & YES \\
Bank FE & YES & YES & YES & YES & YES \\
Year FE & YES & YES & YES & & 125440 \\
& & & & 249110 & 0.001 \\
Observations & 77934 & 58522 & 129085 & 0.000 & 3922 \\
R-Squared & 0.007 & 0.011 & 0.001 & 3996 & 90 \\
No. Firms & 3205 & 3240 & 3945 & 92 & \\
No. Issuers & 79 & 86 & 90 & & \\
\hline
\end{tabular}

Panel B. Firm Level Analysis

\begin{tabular}{|c|c|c|c|c|c|c|}
\hline & \multicolumn{2}{|c|}{ Lending Rates } & \multicolumn{3}{|c|}{ Lending Volumes } & \multirow{2}{*}{$\begin{array}{c}\text { Debt } \\
\text { Total Financial Debt }\end{array}$} \\
\hline & Advances & Long-Term & Credit Used & Credit Granted & Used / Granted & \\
\hline Minibond * Post & $\begin{array}{c}-0.293 * * * \\
{[0.102]}\end{array}$ & $\begin{array}{c}-0.446^{* * *} \\
{[0.139]}\end{array}$ & $\begin{array}{c}-0.312 * * * \\
{[0.110]}\end{array}$ & $\begin{array}{c}-0.088 \\
{[0.065]}\end{array}$ & $\begin{array}{c}-0.094 * * * \\
{[0.018]}\end{array}$ & $\begin{array}{c}0.427 * * * \\
{[0.059]}\end{array}$ \\
\hline Firm Controls & YES & YES & YES & YES & YES & YES \\
\hline Firm FE & YES & YES & YES & YES & YES & YES \\
\hline Year FE & YES & YES & YES & YES & YES & YES \\
\hline Observations & 15532 & 15853 & 19531 & 19531 & 19372 & 19531 \\
\hline R-Squared & 0.025 & 0.059 & 0.005 & 0.013 & 0.009 & 0.005 \\
\hline No. Firms & 3231 & 3307 & 3945 & 3945 & 3922 & 3945 \\
\hline No. Issuers & 80 & 87 & 90 & 90 & 90 & 90 \\
\hline
\end{tabular}




\section{Appendix B}

\section{Table B.1. Firm Level Analysis}

\section{Effects of the First Minibond Issuance on}

\section{Firm Ex-post Outcomes (one year before vs one year after)}

This table presents the results of the difference-in-differences estimation for the ex-post changes in the balance sheet and the performance of issuer firms after the first issuance of minibonds. We explore whether and how issuer firms changed their balance sheet composition, turnover and profitability, in the year after the first issuance. The treatment corresponds to the first issuance of a minibond. The control sample includes ex-ante comparable non-issuer firms identified on the basis of a coarsened exact matching based on ex-ante firm level characteristics. The Minibond dummy is equal to 1 for the firms issuing minibonds, while the Post dummy is equal to 1 for the year following the minibond issuance. Given the inclusion of firm and time fixed effects, the coefficient for the interaction between the first minibond issuance (Minibond) and the post-issuance dummy (Post) defines the average treatment effect of the first issuance on firm balance sheet and performance. We consider each dependent variable one year before the first issuance $($ Post $=0)$, against the year after the issuance $(\mathrm{Post}=1)$. The issuance period considered in the estimates is between the fourth quarter of 2012 and the fourth quarter of 2016; the overall sample period for firm balance sheets consider annual data from 2012 to 2017 . Standard errors are clustered at firm level. Regressions are weighted with CEM strata weights. ***, **, * indicate, respectively, statistical significance at 1, 5, 10 percent level.

\begin{tabular}{|c|c|c|c|c|c|c|c|}
\hline \multicolumn{8}{|c|}{ ASSETS } \\
\hline & (1) & (2) & (3) & (4) & (5) & (6) & (7) \\
\hline VARIABLES & $\begin{array}{l}\text { Ln total } \\
\text { assets }\end{array}$ & $\begin{array}{l}\text { Ln total } \\
\text { fixed assets }\end{array}$ & $\begin{array}{c}\text { Ln } \\
\text { tangible } \\
\text { fixed assets }\end{array}$ & $\begin{array}{c}\text { Ln } \\
\text { intangible } \\
\text { fixed assets }\end{array}$ & $\begin{array}{l}\text { Total fixed } \\
\text { assets/ Total } \\
\text { assets }\end{array}$ & $\begin{array}{c}\text { Tangible } \\
\text { fixed assets/ } \\
\text { Total assets }\end{array}$ & $\begin{array}{c}\text { Intangible } \\
\text { fixed assets/ } \\
\text { Total assets }\end{array}$ \\
\hline Minibond * Post & $\begin{array}{c}0.150 * * * \\
{[0.031]}\end{array}$ & $\begin{array}{c}0.101 \\
{[0.067]}\end{array}$ & $\begin{array}{c}0.050 \\
{[0.061]}\end{array}$ & $\begin{array}{c}0.170 \\
{[0.118]}\end{array}$ & $\begin{array}{c}-0.009 \\
{[0.009]}\end{array}$ & $\begin{array}{c}-0.007 \\
{[0.007]}\end{array}$ & $\begin{array}{c}-0.001 \\
{[0.006]}\end{array}$ \\
\hline Firm FE & YES & YES & YES & YES & YES & YES & YES \\
\hline Year FE & YES & YES & YES & YES & YES & YES & YES \\
\hline Observations & 5273 & 5254 & 5231 & 4963 & 5273 & 5273 & 5273 \\
\hline R-squared & 0.035 & 0.023 & 0.023 & 0.019 & 0.010 & 0.010 & 0.016 \\
\hline No. Firms & 84 & 84 & 84 & 81 & 84 & 84 & 84 \\
\hline No. Issuers & 2721 & 2717 & 2710 & 2620 & 2721 & 2721 & 2721 \\
\hline
\end{tabular}

\begin{tabular}{|c|c|c|c|c|c|c|}
\hline & \multicolumn{3}{|c|}{ LIABILITIES } & \multicolumn{3}{|c|}{ TURNOVER AND PROFITABILITY } \\
\hline & (8) & $(9)$ & (10) & (11) & $(12)$ & (13) \\
\hline VARIABLES & $\begin{array}{c}\text { Bank debt/ } \\
\text { Total } \\
\text { financial } \\
\text { debt }\end{array}$ & $\begin{array}{c}\text { Total } \\
\text { financial } \\
\text { debt/ } \\
\text { Turnover }\end{array}$ & Leverage & Ln turnover & $\mathbf{R o A}$ & RoE \\
\hline Minibond * Post & $\begin{array}{c}-0.244 * * * \\
{[0.028]}\end{array}$ & $\begin{array}{l}0.242 * \\
{[0.136]}\end{array}$ & $\begin{array}{c}0.093 * * * \\
{[0.018]}\end{array}$ & $\begin{array}{c}0.030 \\
{[0.046]}\end{array}$ & $\begin{array}{c}-2.244 * * * \\
{[0.771]}\end{array}$ & $\begin{array}{l}-6.356 \\
{[4.543]}\end{array}$ \\
\hline Firm FE & YES & YES & YES & YES & YES & YES \\
\hline Year FE & YES & YES & YES & YES & YES & YES \\
\hline Observations & 5144 & 5263 & 5273 & 5263 & 5273 & 5270 \\
\hline R-squared & 0.066 & 0.043 & 0.049 & 0.007 & 0.013 & 0.014 \\
\hline No. Firms & 84 & 84 & 84 & 84 & 84 & 84 \\
\hline No Issuers & 2693 & 2720 & 2721 & 2720 & 2721 & 2721 \\
\hline
\end{tabular}




\section{RECENTLY PUBLISHED “TEMI” (*)}

N.1294 - Prudential policies, credit supply and house prices: evidence from Italy, by Pierluigi Bologna, Wanda Cornacchia and Maddalena Galardo (September 2020).

N. 1295 - How loose, how tight? A measure of monetary and fiscal stance for the euro area, by Nicoletta Batini, Alessandro Cantelmo, Giovanni Melina and Stefania Villa (September 2020).

N.1296 - Price dividend ratio and long-run stock returns: a score driven state space model, by Davide Delle Monache, Ivan Petrella and Fabrizio Venditti (September 2020).

N.1297 - Workforce aging, pension reforms, and firm outcomes, by Francesca Carta, Francesco D'Amuri and Till von Wachter (September 2020).

N.1298 - Anti-poverty measures in Italy: a microsimulation analysis, by Nicola Curci, Giuseppe Grasso, Pasquale Recchia and Marco Savegnago (September 2020).

N.1299 - Forecasting US recessions: the role of economic uncertainty, by Valerio Ercolani and Filippo Natoli (September 2020).

N. 1300 - Demographics and the natural real interest rate: historical and projected paths for the euro area, by Andrea Papetti (November 2020).

N.1301 - A quantitative analysis of distortions in managerial forecasts, by Yueran Ma, Tiziano Ropele, David Sraer and David Thesmar (November 2020).

N. 1302 - Bargaining power and the Phillips curve: a micro-macro analysis, by Marco J. Lombardi, Marianna Riggi and Eliana Viviano (November 2020).

N.1303 - The effects of structural reforms: Evidence from Italy, by Emanuela Ciapanna, Sauro Mocetti and Alessandro Notarpietro (November 2020).

N.1304 - Consumption and Wealth: New Evidence from Italy, by Riccardo De Bonis, Danilo Liberati, John Muellbauer and Concetta Rondinelli (November 2020).

N.1305 - Do details matter? An analysis of the Italian personal income tax, by Martino Tasso (November 2020).

N. 1306 - Effects of eligibility for central bank purchases on corporate bond spreads, by Taneli Mäkinen, Fan Li, Andrea Mercatanti and Andrea Silvestrini (November 2020).

N. 1307 - On the design of grant assignment rules, by Francesca Modena, Santiago Pereda Fernandez and Giulia Martina Tanzi (December 2020).

N. 1308 - Monetary policy strategies in the New Normal: a model-based analysis for the euro area, by Fabio Busetti, Stefano Neri, Alessandro Notarpietro and Massimiliano Pisani (December 2020).

N.1309 - Rare disasters, the natural interest rate and monetary policy, by Alessandro Cantelmo (December 2020).

N.1310 - The market stabilization role of central bank asset purchases: high-frequency evidence from the COVID-19 crisis, by Marco Bernardini and Annalisa De Nicola (December 2020).

N.1311 - Equity tail risk in the treasury bond market, by Dario Ruzzi and Mirco Rubin (December 2020).

N. 1312 - Scars of youth non-employment and labour market conditions, by Giulia Martina Tanzi (December 2020).

N. 1313 - The COVID-19 shock and a fiscal-monetary policy mix in a monetary union, by Anna Bartocci, Alessandro Notarpietro and Massimiliano Pisani (December 2020).

(*) Requests for copies should be sent to:

Banca d'Italia - Servizio Studi di struttura economica e finanziaria - Divisione Biblioteca e Archivio storico - Via Nazionale, 91 - 00184 Rome - (fax 003906 47922059). They are available on the Internet www.bancaditalia.it. 
ALBANESE G., M. CIOFFI and P. TOMMASINO, Legislators' behaviour and electoral rules: evidence from an Italian reform, European Journal of Political Economy, v. 59, pp. 423-444, WP 1135 (September 2017).

Aprigliano V., G. ARDizzI and L. MONTEFORTE, Using the payment system data to forecast the economic activity, International Journal of Central Banking, v. 15, 4, pp. 55-80, WP 1098 (February 2017).

ARnAudo D., G. MiCUCCI, M. RIGON and P. Rossi, Should I stay or should I go? Firms' mobility across banks in the aftermath of the financial crisis, Italian Economic Journal / Rivista italiana degli economisti, v. 5, 1, pp. 17-37, WP 1086 (October 2016).

BASSO G., F. D'AMURI and G. PERI, Immigrants, labor market dynamics and adjustment to shocks in the euro area, IMF Economic Review, v. 67, 3, pp. 528-572, WP 1195 (November 2018).

BAtini N., G. MELINA and S. VILla, Fiscal buffers, private debt, and recession: the good, the bad and the ugly, Journal of Macroeconomics, v. 62, WP 1186 (July 2018).

Burlon L., A. NotARPIETRO and M. PISANI, Macroeconomic effects of an open-ended asset purchase programme, Journal of Policy Modeling, v. 41, 6, pp. 1144-1159, WP 1185 (July 2018).

BUSETTI F. and M. CAIVANO, Low frequency drivers of the real interest rate: empirical evidence for advanced economies, International Finance, v. 22, 2, pp. 171-185, WP 1132 (September 2017).

CAPpelletti G., G. GuAZZAROtTI and P. TOMmasino, Tax deferral and mutual fund inflows: evidence from a quasi-natural experiment, Fiscal Studies, v. 40, 2, pp. 211-237, WP 938 (November 2013).

CARDANi R., A. PACCAGNINI and S. VILLA, Forecasting with instabilities: an application to DSGE models with financial frictions, Journal of Macroeconomics, v. 61, WP 1234 (September 2019).

Chiades P., L. Greco, V. Mengotto, L. Moretti and P. VAlbonesi, Fiscal consolidation by intergovernmental transfers cuts? The unpleasant effect on expenditure arrears, Economic Modelling, v. 77, pp. 266-275, WP 1076 (July 2016).

CIANI E., F. DAVID and G. DE BLASIO, Local responses to labor demand shocks: a re-assessment of the case of Italy, Regional Science and Urban Economics, v. 75, pp. 1-21, WP 1112 (April 2017).

CIANI E. and P. FISHER, Dif-in-dif estimators of multiplicative treatment effects, Journal of Econometric Methods, v. 8. 1, pp. 1-10, WP 985 (November 2014).

CIAPANNA E. and M. TABOGA, Bayesian analysis of coefficient instability in dynamic regressions, Econometrics, MDPI, Open Access Journal, v. 7, 3, pp.1-32, WP 836 (November 2011).

Coletta M., R. De Bonis and S. Piermattei, Household debt in OECD countries: the role of supply-side and demand-side factors, Social Indicators Research, v. 143, 3, pp. 1185-1217, WP 989 (November 2014).

Cova P., P. PAgAno and M. PISANI, Domestic and international effects of the Eurosystem Expanded Asset Purchase Programme, IMF Economic Review, v. 67, 2, pp. 315-348, WP 1036 (October 2015).

ERCOLANI V. and J. VALLE E AZEVEDO, How can the government spending multiplier be small at the zero lower bound?, Macroeconomic Dynamics, v. 23, 8. pp. 3457-2482, WP 1174 (April 2018).

FERrERo G., M. GROSS and S. NERI, On secular stagnation and low interest rates: demography matters, International Finance, v. 22, 3, pp. 262-278, WP 1137 (September 2017).

FoA G., L. GAmBACORTA, L. Guiso and P. E. Mistrulli, The supply side of household finance, Review of Financial Studies, v.32, 10, pp. 3762-3798, WP 1044 (November 2015).

GerAli A. and S. NERI, Natural rates across the Atlantic, Journal of Macroeconomics, v. 62, article 103019, WP 1140 (September 2017).

GIORDANO C., M. MARINUCCI and A. SILVESTRINI, The macro determinants of firms' and households' investment: evidence from Italy, Economic Modelling, v. 78, pp. 118-133, WP 1167 (March 2018).

GOMEllini M., D. PELlEGRINO and F. GIFFONI, Human capital and urban growth in Italy, 1981-2001, Review of Urban \& Regional Development Studies, v. 31, 2, pp. 77-101, WP 1127 (July 2017).

LiBERATI D. and M. LOBERTO, Taxation and housing markets with search frictions, Journal of Housing Economics, v. 46, article 101632, WP 1105 (March 2017).

MAGRI S., Are lenders using risk-based pricing in the Italian consumer loan market? The effect of the 2008 crisis, Journal of Credit Risk, v. 15, 1, pp. 27-65, WP 1164 (January 2018).

Mercatanti A., T. MAKINEN and A. SiLVESTRINI, The role of financial factors for european corporate investment, Journal of International Money and Finance, v. 96, pp. 246-258, WP 1148 (October 2017). 
Miglietta A., C. Picillo and M. PIETRUnTI, The impact of margin policies on the Italian repo market, The North American Journal of Economics and Finance, v. 50, WP 1028 (October 2015).

MONTEFORTE L. and V. RAPONI, Short-term forecasts of economic activity: are fortnightly factors useful?, Journal of Forecasting, v. 38, 3, pp. 207-221, WP 1177 (June 2018).

Neri S. and A. NotArpietro, Collateral constraints, the zero lower bound, and the debt-deflation mechanism, Economics Letters, v. 174, pp. 144-148, WP 1040 (November 2015).

PANCRAZI R. and M. PIETRUNTI, Natural expectations and home equity extraction, Journal of Housing Economics, v. 46, 4, WP 984 (November 2014).

Pereda FERnANDEZ S., Teachers and cheaters. Just an anagram?, Journal of Human Capital, v. 13, 4, pp. 635-669, WP 1047 (January 2016).

RigGi M., Capital destruction, jobless recoveries, and the discipline device role of unemployment, Macroeconomic Dynamics, v. 23, 2, pp. 590-624, WP 871 (July 2012).

AlessANDRi P. and M. BOTTERO, Bank lending in uncertain times, R European Economic Review, V. 128, WP 1109 (April 2017).

Antunes A. and V. ERCOlAnI, Public debt expansions and the dynamics of the household borrowing constraint, Review of Economic Dynamics, v. 37, pp. 1-32, WP 1268 (March 2020).

ARDUINI T., E. PATACCHINI and E. RAINONE, Treatment effects with heterogeneous externalities, Journal of Business \& Economic Statistics, , v. 38, 4, pp. 826-838, WP 974 (October 2014).

Bottero M., F. MeZZANOTTI and S. LENZU, Sovereign debt exposure and the Bank Lending Channel: impact on credit supply and the real economy, Journal of International Economics, v. 126, article 103328, WP 1032 (October 2015).

BRIPI F., D. LOSCHIAVO and D. REVELLI, Services trade and credit frictions: evidence with matched bankfirm data, The World Economy, v. 43, 5, pp. 1216-1252, WP 1110 (April 2017).

BRONZINI R., G. CARAMELLINO and S. MAGRI, Venture capitalists at work: a Diff-in-Diff approach at latestages of the screening process, Journal of Business Venturing, v. 35, 3, WP 1131 (September 2017).

BronzINI R., S. MocetTI and M. MONGARDINI, The economic effects of big events: evidence from the Great Jubilee 2000 in Rome, Journal of Regional Science, v. 60, 4, pp. 801-822, WP 1208 (February 2019).

COIBION O., Y. GORODNICHENKO and T. ROPELE, Inflation expectations and firms' decisions: new causal evidence, Quarterly Journal of Economics, v. 135, 1, pp. 165-219, WP 1219 (April 2019).

CORSELlO F. and V. NiSPI LANDI, Labor market and financial shocks: a time-varying analysis, Journal of Money, Credit and Banking, v. 52, 4, pp. 777-801, WP 1179 (June 2018).

COVA P. and F. NATOLI, The risk-taking channel of international financial flows, Journal of International Money and Finance, v. 102, WP 1152 (December 2017).

D'Alessio G., Measurement errors in survey data and the estimation of poverty and inequality indices, Statistica Applicata - Italian Journal of Applied Statistics, v. 32, 3, WP 1116 (June 2017).

Del Prete S. and S. FEDERICO, Do links between banks matter for bilateral trade? Evidence from financial crises, Review of World Economic, v. 156, 4, pp. 859 - 885, WP 1217 (April 2019).

D'IGNAZIO A. and C. MENON, The causal effect of credit Guarantees for SMEs: evidence from Italy, The Scandinavian Journal of Economics, v. 122, 1, pp. 191-218, WP 900 (February 2013).

ERCOLANI V. and F. NATOLI, Forecasting US recessions: the role of economic uncertainty, Economics Letters, v. 193, WP 1299 (October 2020).

MAKINEN T., L. SARNO and G. ZINNA, Risky bank guarantees, Journal of Financial Economics, v. 136, 2, pp. 490522, WP 1232 (July 2019).

MOdEnA F., E. RETTORE and G. M. TANZI, The effect of grants on university dropout rates: evidence from the Italian case, Journal of Human Capital, v. 14, 3, pp. 343-370, WP 1193 (September 2018).

NiSPI LANDI V., Capital controls spillovers, Journal of International Money and Finance, v. 109, WP 1184 (July 2018).

PERICOLI M., On risk factors of the stock-bond correlation, International Finance, v. 23, 3, pp. 392-416, WP 1198 (November 2018). 
RAINONE E., The network nature of OTC interest rates, Journal of Financial Markets, v.47, article 100525, WP 1022 (July 2015).

RAINONE E. and F. VACIRCA, Estimating the money market microstructure with negative and zero interest rates, Quantitative Finance, v. 20, 2, pp. 207-234, WP 1059 (March 2016).

RIZZICA L., Raising aspirations and higher education. Evidence from the UK's widening participation policy, Journal of Labor Economics, v. 38, 1, pp. 183-214, WP 1188 (September 2018).

SANTIONI, R., F. SCHIANTARELLI and P. STRAHAN, Internal capital markets in times of crisis: the benefit of group affiliation, Review of Finance, v. 24, 4, pp. 773-811, WP 1146 (October 2017).

SChiantarelli F., M. Stacchini and P. Strahan, Bank Quality, judicial efficiency and loan repayment delays in Italy, Journal of Finance, v. 75, 4, pp. 2139-2178, WP 1072 (July 2016).

\section{FORTHCOMING}

Accetturo A., A. LAmorgese, S. Mocetti and D. Pellegrino, Housing Price elasticity and growth: evidence from Italian cities, Journal of Economic Geography, WP 1267 (March 2020).

AlBAnese G., E. CIANI and G. DE BLASIO, Anything new in town? The local effects of urban regeneration policies in Italy, Regional Science and Urban Economics, WP 1214 (April 2019).

Albanese G., G. DE BlAsio and A. LOCATELLI, Does EU regional policy promote local TFP growth? Evidence from the Italian Mezzogiorno, Papers in Regional Science, WP 1253 (December 2019).

ANZUINI A. and L. Rossi, Fiscal policy in the US: a new measure of uncertainty and its effects on the American economy, Empirical Economics, WP 1197 (November 2018).

Bologna P., A. Miglietta and A. Segura, Contagion in the CoCos market? A case study of two stress events, International Journal of Central Banking, WP 1201 (November 2018).

Cova P., P. PAgAnO, A. NotARPIETRO and M. PisAni, Secular stagnation, R\&D, public investment and monetary policy: a global-model perspective, Macroeconomic Dynamics, WP 1156 (December 2017).

DE PHILIPPIS M., Multitask agents and incentives: the case of teaching and research for university professors, Economic Journal, WP 1156 (December 2015).

Del Prete S. and M. L. SteFAni, Women as "Gold Dust": gender diversity in top boards and the performance of Italian banks, Economic Notes, Monte dei Paschi di Siena, WP 1014 (June 2015).

Fidora M., C. GIORDANO and M. SchMitz, Real exchange rate misalignments in the Euro Area, Open Economies Review, WP 1042 (January 2018).

HERTWECK M., V. LEWIS and S. VILLA, Going the extra mile: effort by workers and job-seekers, Journal of Money, Credit and Banking, WP 1277 (June 2020).

Li F., A. MercatAnti, T. MAKINEN and A. SilveSTRINI, A regression discontinuity design for ordinal running variables: evaluating central bank purchases of corporate bonds, Annals of Applied Statistics, WP 1213 (March 2019).

LOSCHIAVO D., Household debt and income inequality: evidence from Italian survey data, Review of Income and Wealth, WP 1095 (January 2017).

METELli L. and F. NATOLI, The international transmission of US tax shocks: a proxy-SVAR approach, IMF Economic Review, WP 1223 (June 2019).

Mocetti S., G. RomA and E. RuBOLINO, Knocking on parents' doors: regulation and intergenerational mobility, Journal of Human Resources, WP 1182 (July 2018).

NisPi LANDI V. and A. SCHIAVONE, The effectiveness of capital controls, Open Economies Review, WP 1200 (November 2018).

PeReda Fernandez S., Copula-based random effects models for clustered data, Journal of Business \& Economic Statistics, WP 1092 (January 2017).

PERICOLI M. and M. TABOGA, Nearly exact Bayesian estimation of non-linear no-arbitrage term-structure models, Journal of Financial Econometrics, WP 1189 (September 2018). 